\title{
RIPENING KINETICS OF IRON SULFIDES IN THE \\ PRESENCE/ABSENCE OF A \\ CARBONYL GROUP
}

\author{
A THESIS IN \\ Environmental and Urban Geosciences
}

Presented to the Faculty of the University Of Missouri-Kansas City in partial fulfillment of

The requirements for the degree

MASTER OF SCIENCE

By

JOSEPH ASHTON NOLAN

B.S., University of Missouri-Kansas City, 2016

Kansas City, Missouri

2018 
(C) 2018

JOSEPH ASHTON NOLAN

ALL RIGHTS RESERVED 


\title{
RIPENING KINETICS OF IRON SULFIDES IN THE
}

\section{PRESENCE/ABSENCE OF A}

\section{CARBONYL GROUP}

Joseph Ashton Nolan, Candidate for the Master of Science Degree

University of Missouri-Kansas City, 2018

\begin{abstract}
The ripening of mackinawite $\left(\mathrm{Fe}_{1+\mathrm{x}} \mathrm{S}\right)$ to pyrite $\left(\mathrm{FeS}_{2}\right)$ or greigite $\left(\mathrm{Fe}^{2+} \mathrm{Fe}^{3+}{ }_{2} \mathrm{~S}_{4}\right)$ was examined at temperatures between 23 and $90^{\circ} \mathrm{C}$ to better understand the kinetics of lowtemperature iron sulfide crystallization in the presence or absence of aldehydes. Mackinawite starting material was synthesized in a glass, thermostatted reaction vessel from aqueous hydrogen sulfide and ferrous ammonium sulfate. Formaldehyde, which acts as an organic switch leading to greigite formation instead of pyrite, was added to the reaction vessel to explore changes in kinetics which produce greigite and suppress pyrite production in the presence of carbonyls. Samples of iron sulfides were collected at predetermined intervals and analyzed by powder XRD.
\end{abstract}

Two distinct ripening pathways were found: if a carbonyl (formaldehyde) was present, mackinawite ripened to greigite. If a carbonyl was absent, the mackinawite ripened to pyrite with small amounts of smythite and pyrrhotite produced along the way. Application of the Johnson-Mehl-Avrami-Kolmogorov equation to better understand the solid-state reaction kinetics suggests that nucleation of the greigite or pyrite begins at the surface of the mackinawite grains. That is consistent with oxidation of the $\mathrm{Fe}^{2+}$ by the carbonyl group to form greigite, or oxidation of the $\mathrm{S}^{2-}$ by $\mathrm{H}_{2} \mathrm{~S}$ to form pyrite as suggested by previous workers. 


\title{
APPROVAL PAGE
}

The faculty listed below, appointed by the Dean of the College of Arts and Sciences, have examined a thesis titled "Ripening Kinetics of Iron Sulfides in the Presence/Absence of a Carbonyl Group", presented by Joseph Ashton Nolan, candidate for the Master of Science degree, and certify that in their opinion it is worthy of acceptance.

\section{Supervisory Committee}

\section{James Murowchick, Ph.D., Committee Chair \\ Department of Geosciences}

\author{
Alison Graettinger, Ph.D. \\ Department of Geosciences
}

Tina Niemi, Ph.D.

Department of Geosciences 


\section{CONTENTS}

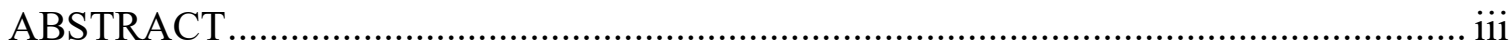

LIST OF TABLES .......................................................................................... vi

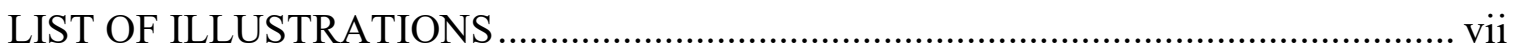

ACKNOWLEDGEMENTS .............................................................................. ix

Chapter

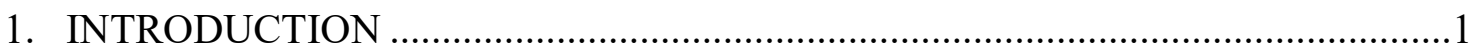

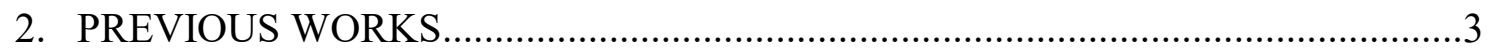

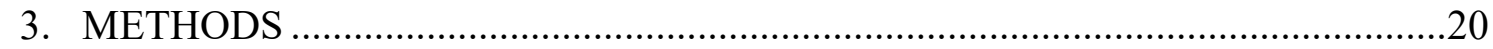

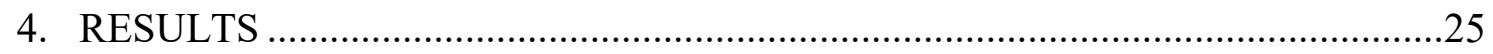

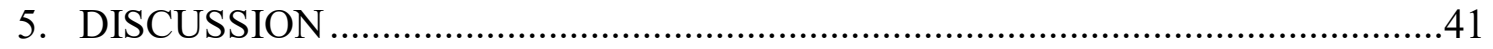

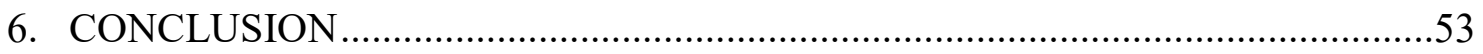

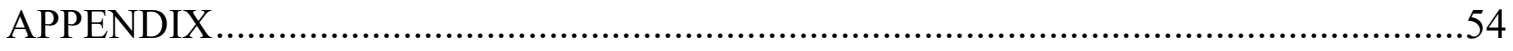

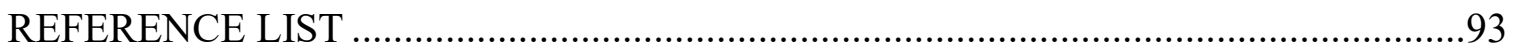

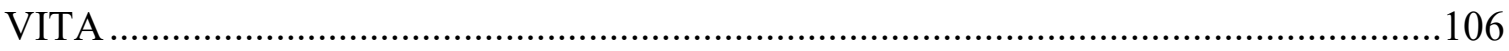




\section{TABLES}

Table $\quad$ Page

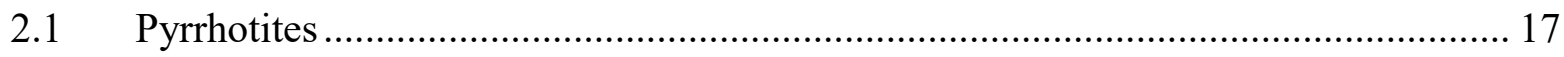

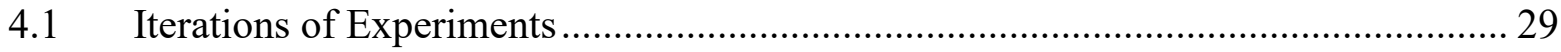




\section{ILLUSTRATIONS}

Figure

Page

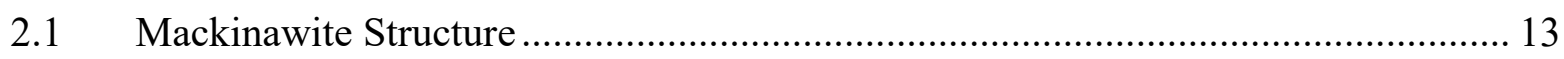

2.2 Greigite and Magnetite Structures .................................................................... 14

2.3 Common Pyrite Habits.................................................................................. 15

2.4 Marcasite and Pyrite Structures ........................................................................ 16

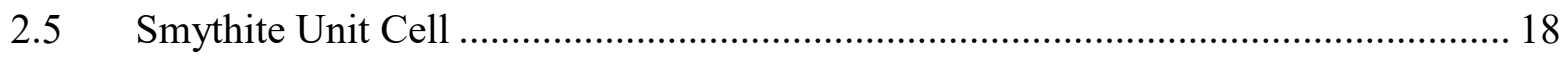

2.6 Iron Sulfide and Aldehydes in Aqueous Environments.................................... 19

3.1 Reaction Vessel Cut Through Sketch ........................................................ 23

Experimental Iron Sulfide Synthesis Apparatus ............................................ 24

4.1 Stacked XRD Patterns at $50^{\circ} \mathrm{C}$ Without Organics ........................................... 28

4.2 Iron Sulfide Phase Percentage at $50^{\circ} \mathrm{C}$ without Organics up to 480 Minutes .......... 30

4.3 Iron Sulfide Phase Percentage at $50^{\circ} \mathrm{C}$ without Organics.................................... 31

4.4 SEM Image at $50^{\circ} \mathrm{C}$ After 240 Minutes of Ripening without Organics - 1 ............ 32

4.5 SEM Image at $50^{\circ} \mathrm{C}$ After 240 Minutes of Ripening without Organics - 2............ 33

4.6 SEM Image at $50^{\circ} \mathrm{C}$ After 480 Minutes of Ripening without Organics .................. 34

4.7 SEM Image at $50^{\circ} \mathrm{C}$ After 4680 Minutes of Ripening without Organics ................ 35

4.8 SEM Image at $50^{\circ} \mathrm{C}$ After 2400 Minutes of Ripening without Organics ................ 36

4.9 SEM Image at $23^{\circ} \mathrm{C}$ After 2400 Minutes of Ripening without Organics ................ 37

4.10 SEM Image at $23^{\circ} \mathrm{C}$ After 4080 Minutes of Ripening without Organics ................ 38

4.11 SEM Image at $50^{\circ} \mathrm{C}$ After 4070 Minutes of Ripening with Organics ..................... 39

4.12 SEM Image at $23^{\circ} \mathrm{C}$ After 4000 Minutes of Ripening with Organics .................... 40

5.1 Mackinawite/Smythite/Greigite Sulfide Lattice ........................................... 46 
5.2 Johnson-Mehl-Avarmi-Kolmogorov Linear Plots without Organics

5.3 Johnson-Mehl-Avarmi-Kolmogorov Plots without Organics............................... 48

5.4 Johnson-Mehl-Avarmi-Kolmogorov Linear Plots with Organics .......................... 49

5.5 Selective Oxidization of Mackinawite 001 Plane ............................................... 50

5.6 Arrhenius Linear Plots without Organics ...................................................... 51

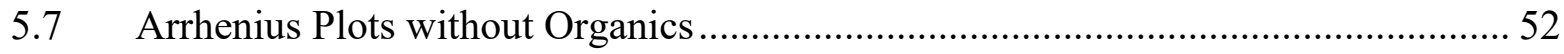




\section{ACKNOWLEDGEMENTS}

Most importantly I would like to thank Dr. James B. Murowchick for having the patience to work with me over the last 2 years. This project has been a struggle for both of us and he has been an incredible promoter. Dr. Tina Niemi and Dr. Alison Graettinger also deserve many accolades, they have been informative, supportive, and instrumental in helping me succeed. Without the guidance of Drs. Niemi and Graettinger, I feel I might not have made it.

Often times people behind the scenes are forgotten when it comes to handing out thanks or acknowledgement in their roles keeping things moving forward together. Much of what the geosciences department accomplishes is due to Megan Medley. Megan works very hard to keep our department running at peak efficiency and sometimes it is a thankless job. Megan, thank you very much for all your help.

On a personal note, my wife and children deserve credit for this degree as much or more than I do. They have been understanding and supportive since day one. My wife and kids are my biggest inspiration in life and without them, I do not know who I would be, so thank you for sticking by me.

Funding for this project was generously provided by, the Newcomb Graduate Student Research Assistance Fund and the Association of Earth Science Clubs of Greater Kansas City. 


\section{CHAPTER 1}

\section{INTRODUCTION}

Metal sulfides comprise a large group of minerals found in nature, however, iron sulfides take most of the scientific attention (Vaughan and Lennie, 1991). Iron sulfides constitute one of the most abundant mineral groups known on Earth (Lin et al., 2018). Previous studies indicate that iron sulfide minerals can serve as paleoenvironmental indicators (Raiswell et al., 1988; Roychoudhury et al., 2003; Taylor and Macquaker, 2011; Li et al., 2017), paleomagnetic proxies (Ariztegui and Dobson, 1996; Horng et al., 1998; Jiang et al., 2001; Horng and Roberts, 2006), and paleoredox markers for the oceans throughout geologic time (Rouxel et al., 2005; Scott et al., 2008; Planavsky et al., 2011; Poulton and Canfield, 2011).

The large range of oxidation states $(-2$ to +6$)$ and coordination geometry (pyramidal, tetrahedral to octahedral) of sulfur and iron $\left(\mathrm{Fe}^{2+}, \mathrm{Fe}^{3+}\right)$ makes its relationship to iron a complex system, so the full nature of the iron sulfide series has yet to be fully evaluated (Bourdoiseau et al., 2010). Because of the range of oxidation states, iron sulfide compounds can be found in igneous, metamorphic, and sedimentary environments, as well as in both lacustrine and marine unconsolidated sediments.

Despite the fine grain size of low-temperature iron sulfides, many can be identified by their crystal habit. Often these iron sulfides, such as mackinawite $(\mathrm{FeS})$, marcasite $\left(\mathrm{FeS}_{2}\right)$, and greigite $\left(\mathrm{Fe}_{3} \mathrm{~S}_{4}\right)$, are stable only in the original environment of deposition. They are replaced by the stable phases, pyrite $\left(\mathrm{FeS}_{2}\right)$ or pyrrhotite $\left(\mathrm{Fe}_{1-\mathrm{x}} \mathrm{S}, \mathrm{x} \leq 0.17\right)($ Berner, 1967) upon aging (table 1.1). Environmental factors, such as $\mathrm{pH}$, sulfur/iron ratios, pressure, or temperature, influence the conversion of metastable iron sulfides to more stable forms (Lennie et al., 1997; Bourdoiseau et al., 2010). Thus, the morphology of the stable iron sulfide can preserve a record 
of the original environment after the environment has changed (Lin et al., 2018). Pseudomorphism and the solid-state transformation from one iron sulfide to a more stable one will be referred to as ripening. Field-acquired specimens of metastable iron sulfides are often pseudomorphs (Rickard and Luther, 2007).

Pyrite is the most abundant and widespread iron sulfide found in crustal metamorphic, igneous, and sedimentary rocks (Bourdoiseau et al., 2010). However, pyrite $\left(\mathrm{FeS}_{2}\right)$ is often ignored as a geological indicator due to its wide range of formation conditions (Murowchick, 1992). Furthermore, pyrite formation often results from the inversion of previous iron sulfides. Pyrite is the dominant iron sulfide produced in anoxic marine environments (Rickard and Luther, 2007). Greigite, often found in low-temperature hydrothermal deposits, was believed to form only through bacterial oxidation of Fe(II) found in FeS to Fe(III) (Vaughan and Lennie, 1991).

While much is known about pyrite, the research on the formation of the mineral greigite until recently had not yet fully described the natural environment of deposition, or whether greigite is biogenic, abiogenic, or both. Determining the process of iron sulfide mineralization pathways to greigite may answer questions about the presence of organic compounds. The focus of this study is to examine the difference in kinetics of ripening between greigite and pyrite in aqueous environments, at low temperatures, with and without the presence of organic compounds. 


\section{CHAPTER 2}

\section{PREVIOUS WORKS}

\section{Mackinawite}

Meyer et al. (1958) described a corrosion product on steel piping during the extraction of sour crude oil; the mineral name kansite was proposed due to the Kansas locality of the oil operations. Four years later a tetragonal iron sulfide mineral was described which was synthesized from steel wires and aqueous sulfide. The XRD pattern for that synthetic iron sulfide was a close match for that of kansite (Berner, 1962). Unfortunately, Milton (1966) published an article bursting the kansite bubble, citing kansite was identical to the mineral mackinawite which had already been described. Since then mackinawite has been the interest of many scientific studies.

In aqueous environments, mackinawite acts as the starting material for other iron sulfide minerals (Lennie et al., 1995, 1997; Rickard and Luther, 2007). Mackinawite forms from solution within the range of $\mathrm{pH}$ 3-4 to $\mathrm{pH} 11$ (Lennie et al., 1995), allowing mackinawite to form in most iron/sulfur-rich aqueous environments. Due to this wide $\mathrm{pH}$ range, mackinawite forms in tidal sediments, hydrothermal, lacustrine, and marine depositional environments, and mackinawite forms directly from amorphous FeS in aqueous environments (Milton, 1966; Rickard and Luther, 2007; White et al., 2015). Mackinawite frequently appears as a black precipitant, however, it can form as crystals (Rickard and Luther, 2007).

The formula for mackinawite is commonly given as $\mathrm{Fe}_{1+\mathrm{x}} \mathrm{S}(\mathrm{x} \leq 0.11)$ (sometimes shown as $\left.\mathrm{Fe}_{9} \mathrm{~S}_{8}\right)($ Nickel, 1979) making mackinawite iron-rich relative to over iron sulfides phases. The iron atoms form sheets of iron with perfect square planar coordination, and 
these iron atoms bond to four equidistant sulfur atoms in a tetrahedral coordination (Rickard and Luther, 2007) (figure 2.1).

A tetragonal mineral (space group P4/nmm), mackinawite forms thin tabular crystals with a truncated $\{111\}$ dipyramid form and a well-developed $\{001\}$ pinacoid. Mackinawite exhibits perfect (001) cleavage; the prominent $\{001\}$ faces serve as the site of nucleation for greigite, smythite, and marcasite to form.

\section{Greigite}

Greigite was first described by Skinner et al. (1964) as the sulfur analog of magnetite $\left(\mathrm{Fe}_{3} \mathrm{O}_{4}\right)$. Both minerals' structures have two ferric iron $\left(\mathrm{Fe}^{3+}\right)$ and one ferrous $\left(\mathrm{Fe}^{2+}\right)$ iron bound to four anions, sulfide $\left(\mathrm{S}^{2-}\right)$ for greigite and oxide $\left(\mathrm{O}^{2-}\right)$ for magnetite (figure 2.2). Magnetite and greigite also share the cubic Fd3m space group and both exhibit ferrimagnetism (Roberts, 1995). Due to its magnetic behavior, greigite has received a great deal of attention as a paleomagnetic proxy (Snowball and Thompson, 1988, 1990; Roberts, 1995; Roberts et al., 2006; Ron et al., 2007). Greigite also forms clusters or framboids of cuboctahedra (Preisinger et al., 2012); similar to the arrangement in pyrite framboids.

Magnetite, greigite, and other iron sulfides, can be formed by bacterial reduction in anoxic waters (Skinner et al., 1964; Mann et al., 1990), either through magnetotatic bacteria (Blakemore, 1975; Devouard et al., 1998; Pósfai et al., 1998; Arakaki et al., 2008; Frankel et al., 2008) or sulfur-reducing prokaryotes (Schieber, 2011). The link to bacteria could imply that greigite is an indicator of microbial organisms. However, greigite has been found in SNC (Shergotty, Nakhla, Chassigny) and EH (enstatite chondrite) group meteorites (El Goresy et al., 1988; McKay et al., 1996), which some believe to have Martian origins (Bridges and 
Warren, 2006). To date, there is no evidence of life outside the planet Earth. Thus, a conflict over the biogenic origin of greigite arises.

Hydrothermal processes produce greigite in less sulfur-rich reducing environments (Krupp, 1994). In laboratory syntheses, greigite has been produced at temperatures ranging from $25^{\circ}$ (Rickard, 1969) to $200^{\circ}$ (Lennie et al., 1997); however some amount of pyrite formed with the greigite. Greigite is stable up to $282^{\circ} \mathrm{C}$. Above $282^{\circ} \mathrm{C}$, it begins to break down to form pyrrhotite as well as sulfur vapor, and then pyrrhotite and pyrite above $320^{\circ} \mathrm{C}$ (Skinner et al., 1964). The upper stability limit of greigite thus constrains the formation of greigite by hydrothermal processes to temperatures below $282^{\circ} \mathrm{C}$.

Greigite is an intermediate phase in ripening mackinawite to other iron sulfides (Krupp, 1994; Lennie et al., 1997; Hunger and Benning, 2007; Rickard and Luther, 2007). Krupp (1994) and Lennie et al. (1997) indicate the sulfurs in the mackinawite structure maintain the same close-packed arrangement during conversion to greigite and then to smythite $\left(\mathrm{Fe}_{13} \mathrm{~S}_{16}\right)$ (figure 2.4). Metastable greigite can ripen along two pathways, to pyrite or to pyrrhotite (Krupp, 1994; Hunger and Benning, 2007; Rickard and Luther, 2007). During formation, mackinawite ripens into greigite, which readily converts to smythite $\left(\mathrm{Fe}_{13} \mathrm{~S}_{16}\right)$ (Krupp, 1994). Attempts to synthesize pyrite or greigite separately or to separate them once formed had proven unsuccessful, until recent studies concluded pyrite formation becomes suppressed in the presence of various organic compounds promoting greigite stability (Rickard et al., 2001; Paolella et al., 2011; Liao et al., 2015; Wang et al., 2015). Rickard et al. (2001) originally proposed that when formaldehyde $\left(\mathrm{CHO}_{2}\right)$, the simplest aldehyde, was added into an aqueous iron sulfide experiment, greigite would exhibit increased stability, while pyrite production was suppressed. Rickard determined that a 2:1 molar ratio of Fe to formaldehyde would fully 
suppress pyrite formation causing greigite to be the dominant species produced. Using iron nanoplatelets, thiosulfate, and 3-methylcatechol, a methyl group organic compound, Paolella et al. (2011) produced greigite; without the added organic compound, mackinawite formed. Expanding on Rickard's original aldehyde work, Wang et al. (2015) found that $\alpha$-oxo acids and aldehydes induced selective oxidation of mackinawite promoting ripening to greigite; the $\alpha$-oxo acids actually produced a pure greigite phase without the various iron sulfide minor phases, smythite, pyrrhotite, and marcasite.

\section{Pyrite}

Pyrite is the most abundant and widely occurring species of iron sulfide found throughout the earth's crust(Vaughan and Lennie, 1991). Stable below $742^{\circ} \mathrm{C}$ (Vaughan and Lennie, 1991), does not provide much use as an environmental indicator. Being isometric pyrite exhibits two common habits, the cube, and the pentagonal dodecahedron or pyritohedron (Stephenson, 1993b) (figure 2.3) as well as several other forms. Pyrite also occurs in octahedral, trapezohedral or diploidal habits, or a combination of these forms (Sunagawa, 1957; Murowchick and Barnes, 1987; Anthony et al., 2001).

Pyrite and greigite form under similar environmental conditions: anoxic aqueous settings, hydrothermal systems, or by the bacterial reduction in low-temperature environments. Marine environments remain a significant source of pyrite production. Rickard (2007) states due to the large amount of sulfate and sulfate reduction in the oceans, an estimated 5,000,000 tons of pyrite is formed annually in marine sediments.

Though largely ignored as a geological indicator, pyrite morphology still reveals some

details about the original environment of formation. Murowchick and Barnes (1987) found 
that pyrite habit is a function of the temperature and growth rates as influenced by the degree of supersaturation. Areal distribution of pyrite habits could help locate the source of hydrothermal fluids. Pyrite with heavily striated surfaces occurs close to the source of heat and nutrients whereas smooth or acicular pyrite forms further away at cooler temperatures and lower saturation levels of iron and sulfur (Murowchick and Barnes, 1987).

\section{Marcasite}

Found commonly in hydrothermal systems and in sedimentary rocks, marcasite is a metastable orthorhombic (Pnnm) polymorph of pyrite (Rickard and Luther, 2007) (figure 2.4). The exact pathway of marcasite formation does remain somewhat unsettled. Marcasite will invert to pyrite, and forms under rather restrictive aqueous parameters: $\mathrm{pH}<5$, temperatures below $240^{\circ} \mathrm{C}$ and deprotonated polysulfides, such as $\mathrm{H}_{2} \mathrm{~S}_{2}$ must be present (Murowchick, 1992). Those restricted criteria for formation make marcasite, and pseudomorphs of marcasite, indicators of the conditions of deposition.

\section{Pyrrhotite Group}

Pyrrhotites represent a wide-spread and abundant series of iron sulfide minerals (Vaughan and Lennie, 1991). Despite the abundance of pyrrhotites in many rocks, the formation process is not fully understood (Rickard and Luther, 2007). Like greigite, the debated about biogenic versus abiogenic formation of pyrrhotite spans decades of research; e.g.(Rickard, 1969; Herbert et al., 1998; Benning et al., 2000; Neal et al., 2001). Hydrothermal ore deposits, hydrothermally altered sediments, and Martian meteorites (Rochette et al., 2001) are known to contain pyrrhotites as a major mineral. Pyrrhotites occur 
as accessory minerals in igneous, metamorphic, and sedimentary rocks (Horng and Roberts, 2006); pyrrhotites also comprise a large portion of the black precipitant found at black smokers along the Mid-Ocean Ridge (Vaughan and Lennie, 1991).

Pyrrhotite group iron sulfides consist of phases with the stoichiometry of $\mathrm{Fe}_{1-\mathrm{x}} \mathrm{S}$, where $\mathrm{x}=0$ to 0.17 . Pyrrhotite was by Ours-Pierre-Armand Petit Dufrenoy in 1847 for the Greek word pyrrhos, referring to the color of fire. The pyrrhotite group represents eight iron sulfide phases (table 2.1); seven of which are stable, and one is metastable. Beyond the stability grouping, natural pyrrhotites are comprised of two subgroups; hexagonal pyrrhotites and monoclinic pyrrhotites (Carpenter and Desborough, 1964).

Like greigite, monoclinic and hexagonal pyrrhotites exhibit ferrimagnetic properties (Menyeh and O'Reilly, 1991; Lennie et al., 1995; Menyeh and O'Reilly, 1995; Horng and Roberts, 2006; Larrasoaña et al., 2007). Monoclinic pyrrhotites tend to be more iron deficient $\left(\mathrm{Fe}_{7} \mathrm{~S}_{8}\right)$ than the hexagonal pyrrhotites (up to troilite, stoichiometric FeS). The monoclinic pyrrhotites tend to be more stable than hexagonal forms at temperatures below $200^{\circ} \mathrm{C}$ (Rickard and Luther, 2007). Though hexagonal pyrrhotites can form at temperatures below $200^{\circ} \mathrm{C}$, Lennie et al (1995) found rapid and consistent hexagonal pyrrhotites formation did not occur until temperatures were above $180^{\circ} \mathrm{C}$.

Troilite, a stable hexagonal low temp phase in the pyrrhotite, is often found in lunar rocks and meteorites (Carpenter and Desborough, 1964) and forms rarely on Earth under strongly reducing environments (Lennie et al., 1995; Thomas et al., 2003). Troilite is stoichiometrically similar to mackinawite $(\mathrm{FeS})$, however, troilite is hexagonal and stable (Rickard and Morse, 2005). Troilite differs structurally from other hexagonal pyrrhotites. Troilite has a hexagonal close-packed structure comprised of $6 \mathrm{FeS}$ and $6 \mathrm{SFe}$ units (Thomas 
et al., 2003); while hexagonal pyrrhotites feature an ideal nickel arsenide (NiAs) (Vaughan and Lennie, 1991; Murowchick, 1992; Krupp, 1994).

The pyrrhotite group features a single metastable phase, smythite. Smythite is structurally similar to hexagonal pyrrhotites, except smythite's structure features an offset along the c-axis which causes distortion and formation of plate-like units which are four sulfur layers thick (Krupp, 1994) (figure 2.5). Smythite's iron atoms are octahedrally coordinated producing an offset plane (Erd et al., 1957; Krupp, 1994). The mineral was originally believed to have the same stoichiometry as greigite $\left(\mathrm{Fe}_{3} \mathrm{~S}_{4}\right)$ due to a lack of irons inside the offset plane. However, Taylor (1970) and Fleet (Fleet, 1982) determined the offset planes contain small numbers of iron atoms making the stoichiometry of smythite more ironrich; today smythite appears as two formulas, $\mathrm{Fe}_{9} \mathrm{~S}_{11}$ or $\mathrm{Fe}_{13} \mathrm{~S}_{16}$.

\section{Iron Sulfide Formation in Aqueous Environments}

There is a well-established association of iron sulfide formation with both marine and lacustrine environments (Berner, 1964; Skinner et al., 1964). Iron eroded from landmasses enters aqueous environments mostly through fluvial and some aeolian transportation. Ocean water contains $3 \mathrm{mg} / \mathrm{L}$ of Fe naturally (Armstrong, 1957), whereas lacustrine Fe concentrations are typically below $1 \mathrm{mg} / \mathrm{L}$ naturally. Population growth, rapid urban sprawl, and industrial growth have increased iron contributions to freshwater systems and have artificially increased iron concentrations in lacustrine and fluvial environments (Xing and Liu, 2011).

In aqueous environments, dissolved iron concentrations are largely controlled by redox reactions. These irons are commonly found as iron oxides, such as hematite $\left(\mathrm{Fe}_{2} \mathrm{O}_{3}\right)$, goethite

$\mathrm{FeO}(\mathrm{OH})$, lepidocrocite $\mathrm{FeO}(\mathrm{OH})$, and ferrihydrite $\left(\left(\mathrm{Fe}^{3+}\right)_{2} \mathrm{O}_{3} \cdot 0.5 \mathrm{H}_{2} \mathrm{O}\right)$, or iron-bearing 
silicates, such as amphiboles, pyroxenes, or biotite (Appelo and Postma, 2005). Near-surface waters contain dissolved oxygen and are termed "euoxic" waters. Euoxic zones can range from 1-2 mm in lacustrine near-surface waters (Revsbech et al., 1981) to several meters in depth in the open ocean (Murray et al., 1989). In the euoxic zone, iron-bearing minerals can undergo dissolution releasing $\mathrm{Fe}^{2+}$ which bond to free oxides and hydroxides forming iron oxyhydroxides (Appelo and Postma, 2005).

With increasing water depth, decaying organic matter depletes dissolved oxygen (figure 2.1) (Mortimer, 1941). As oxygen levels decrease, sulfur levels increase in the suboxic zone. The suboxic zone hosts the last detectable amount of oxygen and marks the switch to sulfur-rich conditions (Rickard and Luther, 2007). In lacustrine waters, the suboxic zone generally starts and ends within a few millimeters of the surface, whereas in ocean settings the suboxic zone spans several centimeters (Revsbech et al., 1981). Ferrous iron washing into lacustrine or marine environments undergoes oxidation to ferric iron $\left(\mathrm{Fe}^{3+}\right)$ in the euoxic and suboxic zones (Rickard and Luther, 2007), but can be reduced back to $\mathrm{Fe}^{2+}$ upon descending below the suboxic zone.

Below the suboxic zone, sulfur becomes the oxidation target in the anoxic zone, while reduction of $\mathrm{Fe}^{3+}$ iron back to $\mathrm{Fe}^{2+}$ occurs (figure 2.4). Aqueous reduced sulfur, as sulfide exists in aqueous solutions mainly in the form of hydrogen sulfide $\left(\mathrm{H}_{2} \mathrm{~S}\right)$ and $\mathrm{HS}^{-}$with trace $\mathrm{S}^{2-}$. Hydrogen sulfide $\left(\mathrm{H}_{2} \mathrm{~S}\right)$ concentrations increase with depth (Rickard and Luther, 2007). Amorphous $\mathrm{FeS}$ begins to form and precipitates. The formation of mackinawite $\left(\mathrm{FeS}_{\mathrm{m}}\right)$ simultaneously occurs by the ripening of amorphous FeS and acts as the base material for more mature iron sulfides, e.g. pyrite, greigite, and pyrrhotite. While iron and sulfur are clearly important, iron sulfide ripening depends on the environmental conditions and non-sulfur 
chemistry; temperature, $\mathrm{pH}$, the absence/presence of organics and other metals, and sulfurreducing prokaryotes, all of which can influence the formation of Fe-S phases.

\section{Aldehydes and Carbonyls in Natural Environments}

Aldehydes are a common organic compound with a - $\mathrm{CHO}$ functional group (Kuykendall, 2010), i.e., a carbonyl group with a hydrogen bonded to the oxygen (figure). Carbonyls are involved in photochemical reactions which are important in atmospheric chemistry, specifically in the tropospheric ozone (Kesselmeier and Staudt, 1999). Presently, the main source of atmospheric aldehydes results from photolysis of incompletely combusted biogenic and anthropogenic hydrocarbons (Otson and Fellin, 1988).

Aldehydes have 5 major natural sources: vegetation (either directly or indirectly), forest fires, microbial processes, insects, and volcanic gases (Kotzias et al., 1997; Schwandner, 2002). Vegetation release terpenes and isoprenes which decompose to various aldehydes in the presence of hydroxyls $\left(\mathrm{OH}^{-}\right)$, nitric oxides (NO), and nitrogen dioxide $\left(\mathrm{NO}_{2}\right)($ Kesselmeier and Staudt, 1999; Atkinson, 2007). This decomposition process may lead to high aldehyde levels in densely vegetated areas, specifically formaldehyde and acetaldehyde (Lloyd et al., 1983). Terpenes are unsaturated hydrocarbons found in essential oils of plants, conifers, and citrus trees (Breitmaier, 2006). Isoprenes comprise liquid hydrocarbons which form natural rubbers (Sharkey, 1996) as well as a byproduct of mammal respiration (Gelmont et al., 1981; King et al., 2010).

Microbes break down glucose to acetaldehyde before forming ethanol (Cox and Nelson, 2008). Decomposition of flora and fauna provides another natural source of aldehydes (Talbot et al., 2012; Forbes and Perrault, 2014). Microbes and insects also facilitate in the 
breakdown of these decaying organisms which expedite the release of aldehydes. Feces represent a common source of naturally occurring aldehydes (Kesselmeier and Staudt, 1999). Low molecular weight aldehydes, especially formaldehyde and acetaldehyde, exhibit a slightly polar nature and therefore are very soluble in water (Stephenson, 1993a). This high solubility allows aldehydes to be carried in ground, surface, and rain waters to aqueous catchments (Van Hoof et al., 1985; Sakugawa et al., 1993; Ivancev-Tumbas and Dalmacija, 2001; Peña et al., 2002). Due to the presence of aldehydes in volcanic gases, subaqueous volcanic activity potentially introduces aldehydes into an aqueous environment.

Since vegetation provides a major source of aldehydes, the decaying vegetation found in the suboxic zone provides aldehydes directly into the aqueous environment, as do marine organisms native to the environment and any unlucky terrestrial organisms. All of these factors combine to make the oceans the second largest source of acetaldehyde (Millet, 2011). Continual natural aldehyde release into aqueous environments occurs at variable rates from both allochthonous and autochthonous sources. 

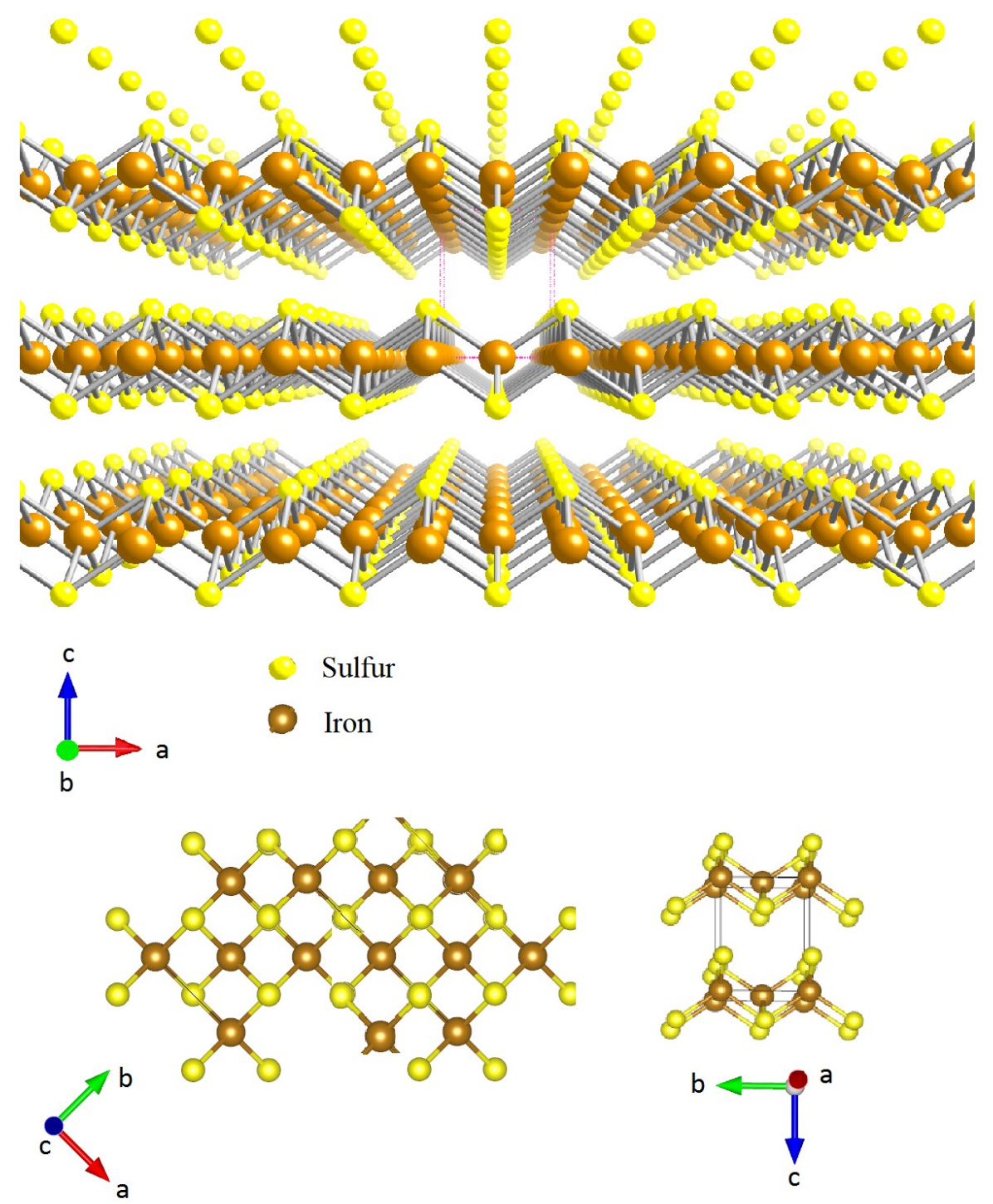

Figure 2.1: The irons in mackinawite form a perfect square plane (bottom-left). Mackinawite forms sheets of iron and sulfur atoms (top) bond in a tetrahedral arrangement (bottom-right). 


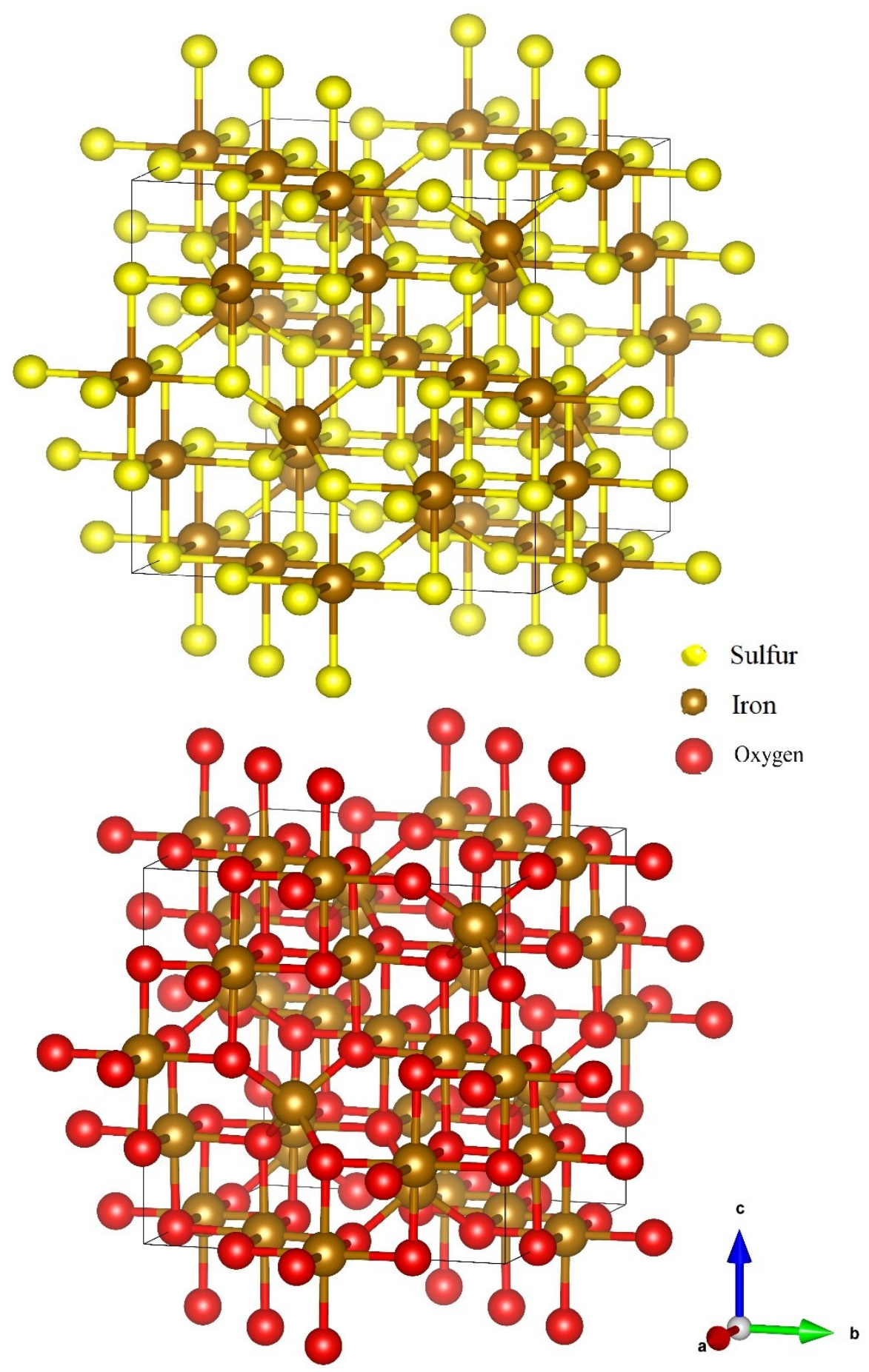

Figure 2.2: Images of the greigite and magnetite atomic structure; top and bottom respectively. Gold spheres represent the location of iron atoms in both structures. Iron locations for both have a similar structure. 

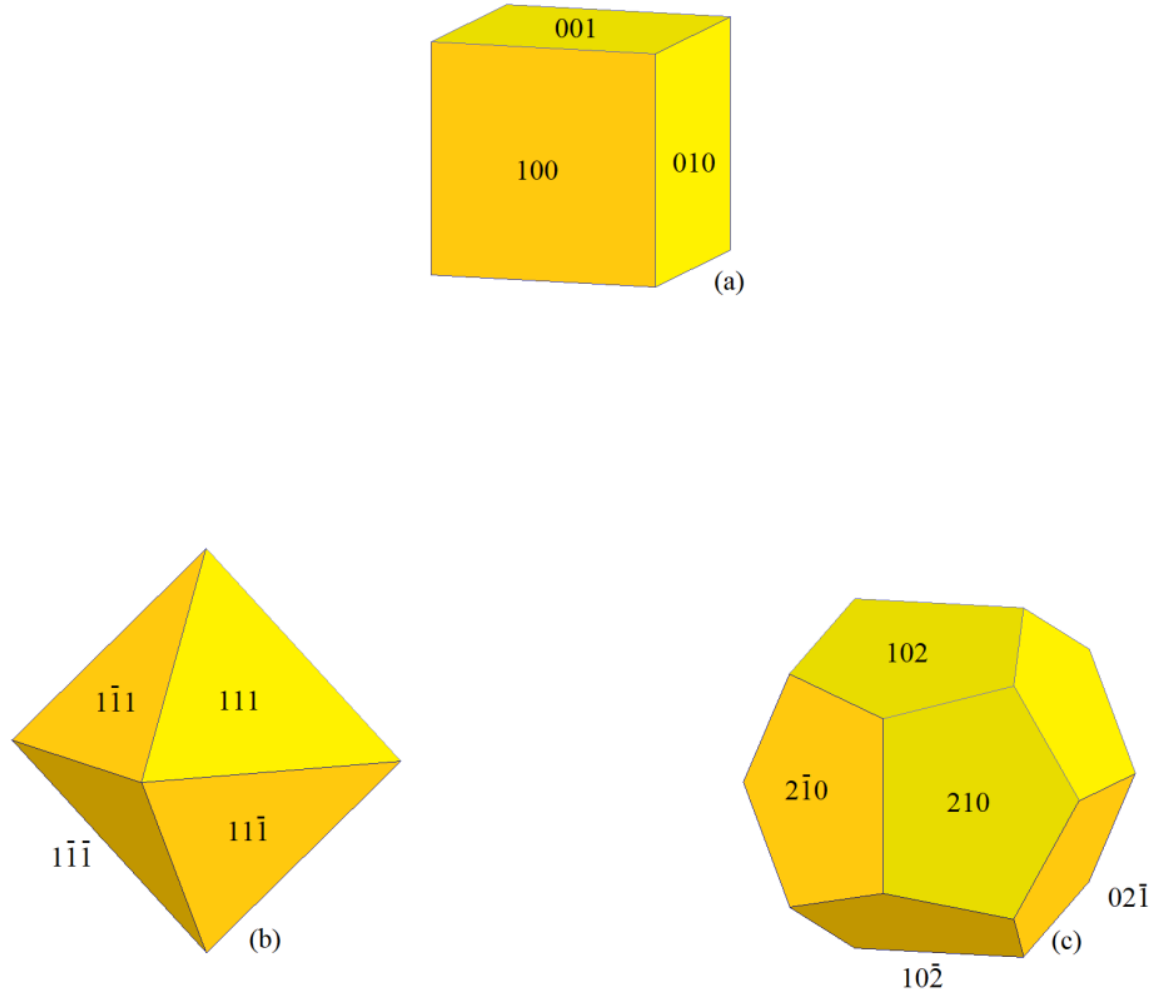

Figure 2.3: Examples of pyrite crystal habits. Pyrite exhibits many distinct habits. Most commonly is the cube (a), octahedra (b), and pyritohedra (c). 


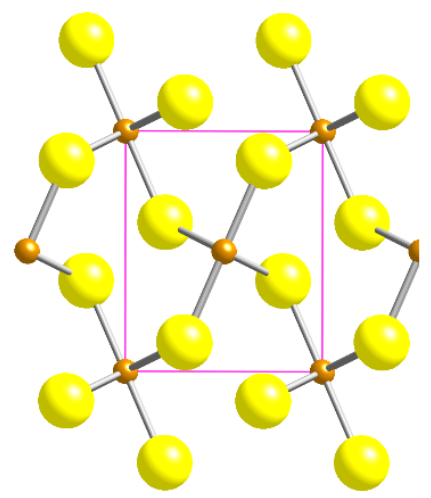

$$
p^{\infty}
$$

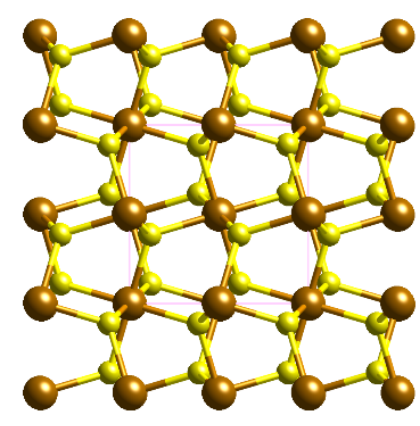

Marcasite

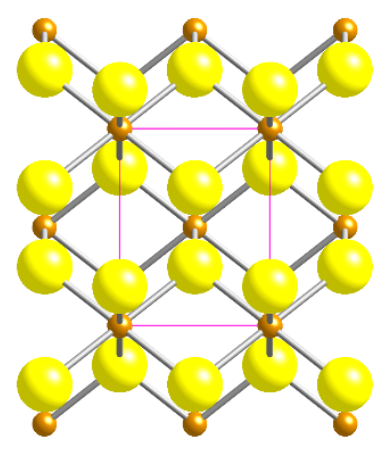

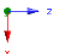

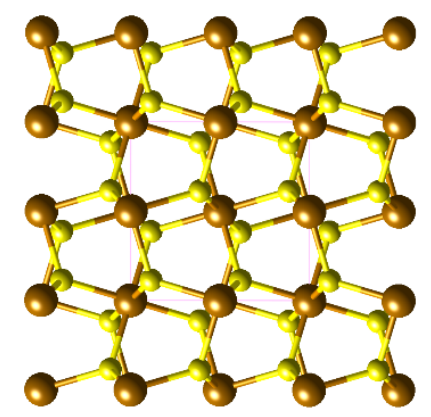

Pyrite

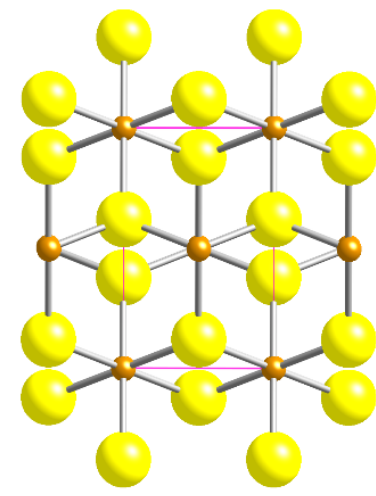

$\dot{p}^{*}$

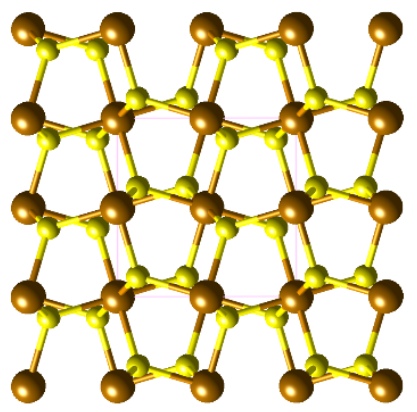

Figure 2.4: Marcasite and pyrite are stoichiometrically similar $\left(\mathrm{FeS}_{2}\right)$, however the atomic structures differ. Pyrite is a stable isometric mineral commonly found in marine environments. Marcasite is a metastable orthorhombic mineral. While much is known about pyrite formation, the formation pathway of marcasite is still under investigation. Marcasite formation requires a specific set of parameters: $\mathrm{pH}<5$, temperature below $240^{\circ} \mathrm{C}$ and deprotonated polysulfides, such as $\mathrm{H} 2 \mathrm{~S} 2$ must be present (Murowchick, 1992). 
Table 2.1: Pyrrhotites ranging from iron rich to iron deficient. Pyrrhotites exhibit hexagonal, orthorhombic, monoclinc, and trigonal forms.

\begin{tabular}{lll} 
Mineral Name & Composition & Crystal System \\
\hline Troilite & $\mathrm{FeS}$ & Hexagonal \\
\hline Pyrrhotite - 11C & $\mathrm{Fe}_{10} \mathrm{~S}_{11}$ & Orthorhombic \\
\hline Pyrrhotite - 11H & $\mathrm{Fe}_{10} \mathrm{~S}_{11}$ & Hexagonal \\
\hline Pyrrhotite - 4C & $\mathrm{Fe}_{7} \mathrm{~S}_{8}$ & Monoclinic \\
\hline Pyrrhotite - 5C & $\mathrm{Fe}_{9} \mathrm{~S}_{10}$ & Monoclinic \\
\hline Pyrrhotite - 6C & $\mathrm{Fe}_{10} \mathrm{~S}_{11}$ & Monoclinic \\
\hline Pyrrhotite - 7H & $\mathrm{Fe}_{10} \mathrm{~S}_{11}$ & Hexagonal \\
\hline Smythite & $\mathrm{Fe}_{9} \mathrm{~S}_{11}$ & Trigonal \\
\hline
\end{tabular}



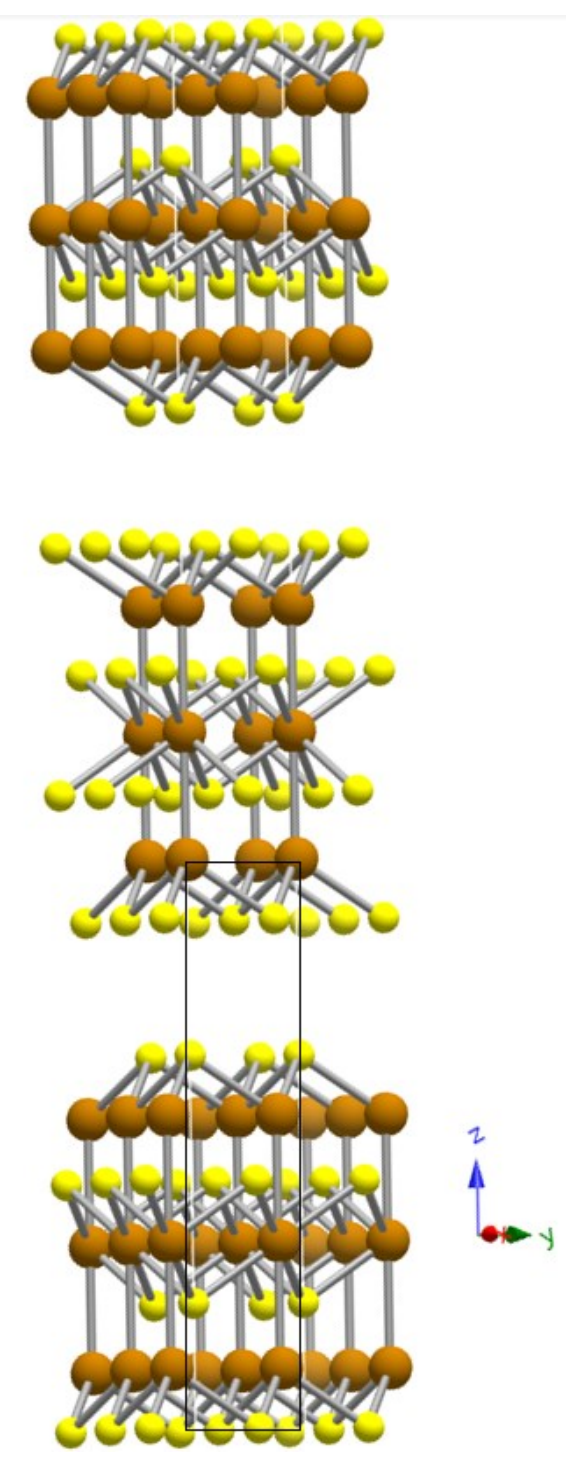

Figure 2.5: Smythite unit cell. Smythite is structurally similar to hexagonal pyrrhotites, except smythite's structure features an offset along the c-axis which causes distortion and formation of plate-like units which are four sulfur layers thick (Krupp, 1994) Smythite's iron atoms are octahedrally coordinated producing an offset plane (Erd et al., 1957; Krupp, 1994). 


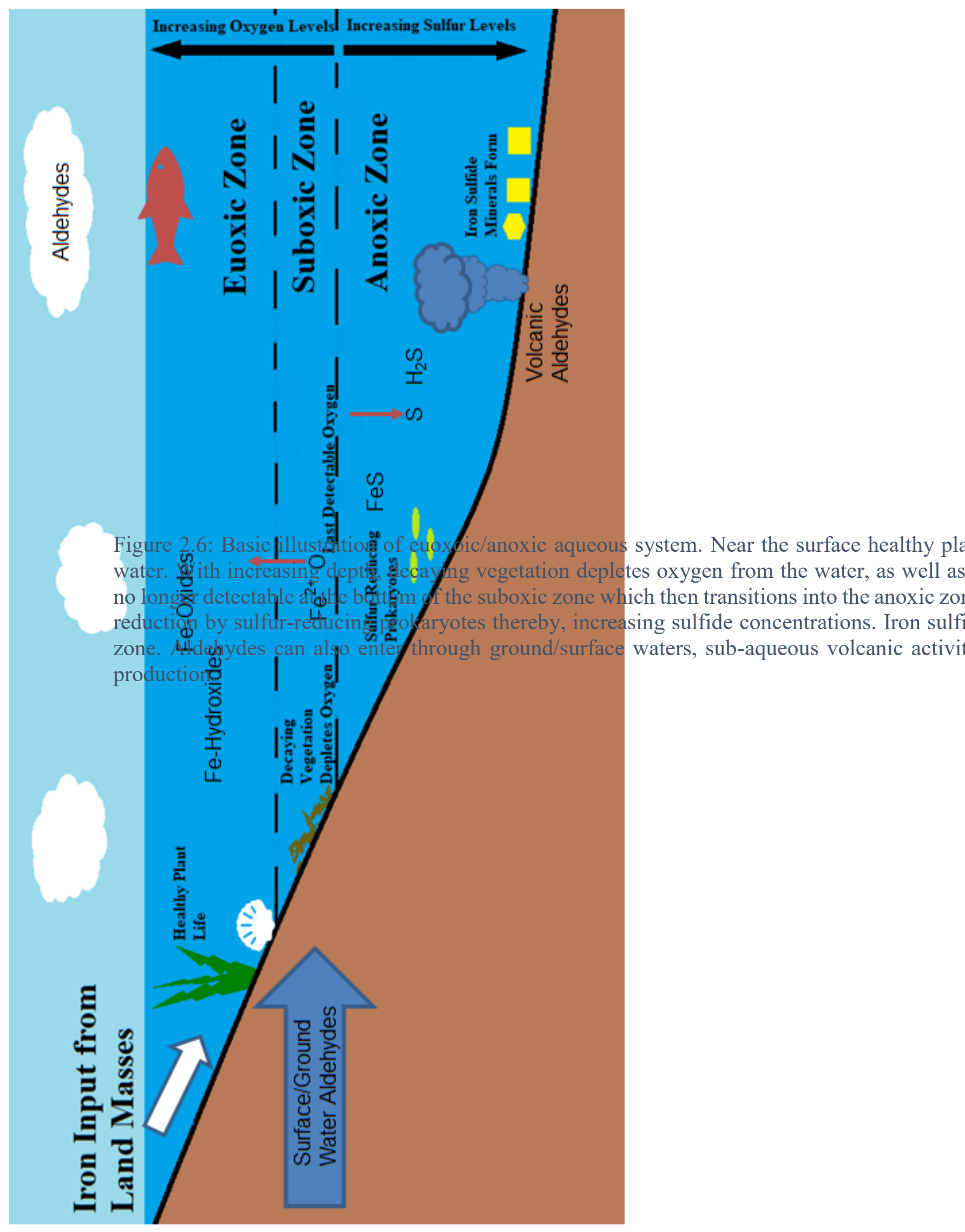




\section{CHAPTER 3}

\section{METHODOLOGY}

A $1460 \mathrm{~mL}$ airtight glass reaction kettle (Murowchick and Barnes, 1986) containing a gas bubbler, extraction and injection tubes, and stirrer assembly (figure 3.1) filled completely with deionized distilled deoxygenated water (DDD water). The reaction vessel is partially immersed in an insulated 10-gallon aquarium that serves as a temperature buffer (figure 3.2). A Fisher Scientific Isotemp Immersion Circulator (model 730) maintains a constant temperature inside the reaction vessel. Hydrogen sulfide $\left(\mathrm{H}_{2} \mathrm{~S}\right)$ gas was bubbled into the reaction vessel at a slight positive pressure; helping ensure no atmospheric contamination. The extraction port was opened and excess DDD water was displaced until the vessel contains about $1 \mathrm{~L}$ of water with $\mathrm{H}_{2} \mathrm{~S}$ in the headspace. The temperature during the experiments was monitored and recorded using a Cole-Palmer 8376-72 Temperature Module.

Hydrogen sulfide $\left(\mathrm{H}_{2} \mathrm{~S}\right)$ was bubbled into the DDD water until saturated; solubility of $\mathrm{H}_{2} \mathrm{~S}$ is such to produce a $0.123 \mathrm{M}$ solution at $298.15 \mathrm{~K}$ at 1 bar (Gevantman, 2015). $\mathrm{H}_{2} \mathrm{~S}$ continued to bubble slowly through the solution to maintain sulfur saturation and positive pressure reducing the risk of atmospheric contamination. Excess $\mathrm{H}_{2} \mathrm{~S}$ left the vessel through a one-way check valve and then into a reservoir of zinc acetate $\left(\mathrm{Zn}\left(\mathrm{O}_{2} \mathrm{CCH}_{3}\right)_{2}\right.$ or zinc chloride $\left(\mathrm{ZnCl}_{2}\right)$ solution. There, the excess $\mathrm{H}_{2} \mathrm{~S}$ precipitated as $\mathrm{ZnS}$. Neutralization of acetic and hydrochloric acid, a byproduct during the scrubbing of excess $\mathrm{H}_{2} \mathrm{~S}$, was accomplished by placing chips of limestone $\left(\mathrm{CaCO}_{3}\right)$ in the scrubber vessel. The final gas product, $\mathrm{CO}_{2}$, passed through another mineral oil bubble trap and into the fume hood.

A $200 \mathrm{~mL} 0.5 \mathrm{~m}$ solution of ferrous ammonium sulfate (FAS) or ferrous sulfate $\left(\mathrm{FeSO}_{4}\right)$, created with DDD water under a nitrogen atmosphere, served as starting material 
for amorphous iron sulfide $\left(\mathrm{FeS}_{\mathrm{am}}\right)$ in the reaction vessel; ferrous sulfate used in runs with formalin addition to alleviating interactions between ammonium and formaldehyde. The addition of this solution to the reaction kettle was accomplished by injection as two $100 \mathrm{~mL}$ aliquots through an airtight Luer lock port. Each $100 \mathrm{~mL}$ aliquot delivered enough ferrous iron $\left(\mathrm{Fe}^{2+}\right)$ to rapidly precipitate $\sim 4.4 \mathrm{~g}$ of $\mathrm{FeS}_{\mathrm{am}}$ per syringe, nearly depleting the available sulfur in the DDD water. After FAS solution injection, $\mathrm{H}_{2} \mathrm{~S}$ bubbled continuously in the DDD water to allow iron sulfide phases to ripen and use the hydrogen sulfide gas as an oxidant (Rickard and Luther, 1997).

Syntheses were also run at each temperature but with $4.8 \mathrm{~mL}$ of formalin $(37.5 \%$ formaldehyde, $15 \%$ methanol, $47.5 \%$ water) to halt the reaction from $\mathrm{FeS}_{\mathrm{am}}$ to greigite $\left(\mathrm{Fe}_{3} \mathrm{~S}_{4}\right)$ rather than allowing the reaction to proceed to pyrite $\left(\mathrm{FeS}_{2}\right)$ formation (Rickard et al., 2001; Hunger and Benning, 2007; Liao et al., 2015; Wang et al., 2015).

Extraction and analysis of the precipitate, at multiple and defined durations (table 3.1), allowed identification of transient iron sulfide phases during the ripening of the $\mathrm{FeS}_{\mathrm{am}}$ to $\mathrm{Fe}_{3} \mathrm{~S}_{4}$ and eventually to pyrite at temperatures from $23^{\circ} \mathrm{C}$ to $90^{\circ} \mathrm{C}$. A $25 \mathrm{~mL}$ aliquot of the precipitate and $\mathrm{H}_{2} \mathrm{~S}$-saturated DDD water was extracted from the reaction vessel by syringe, and then forced through a $0.45 \mathrm{um}$ polycarbonate filter to collect the precipitate; to ensure homogeneity of the solution stirrer remains on. The precipitate and filter (still in the enclosed filter housing) were flushed with acetone reducing the risk of rapid oxidation in the open atmosphere. If the dried powder is too reactive in the air (hydrophilic and pyrophoric), the powder can be treated with a dilute solution of cellulose acetate cement (e.g., Duco cement) dissolved in acetone to coat the particles and reduce their reactivity without appreciably interfering with analytical methods (powder X-ray diffraction). 
Powder X-ray diffractometry (Rigaku Miniflex diffractometer, Co target tube with iron foil filter; $0.052 \Theta$ steps at 1.5 seconds count per step, $\left.5-60^{\circ} 2 \Theta\right)$ was used to identify the phases present in the precipitate. Relative proportions of the phases in the precipitate were obtained using quantitative Rietveld analysis using Profex 3.12.1 (Doebelin and Kleeberg, 2015).

Form factor and atomic scatter calculations were carried out to determine relative intensities of major phases, pyrite, mackinawite, and greigite. Using integrated peak calculations the ratios of pyrite/greigite formation from mackinawite were applied to the Johnson-Mehl-Avrami-Kolmogorov (JMAK) theory of solid-state transformations (Weinberg et al., 1997). Rate constants of the conversion of mackinawite to pyrite were calculated for each experiment. Lastly, the Arrhenius equation was applied to experimental data to determine the effect of temperature on the rate constant, as well as the activation energy of ripening from mackinawite to pyrite.

Morphological features of the precipitate grains were observed by scanning electron microscopy, using a Tescan Vega 3 LMU variable pressure SEM. Samples at the same extraction intervals as PXRD were used in order to visually determine differences in the ripening with and without formaldehyde doping. 


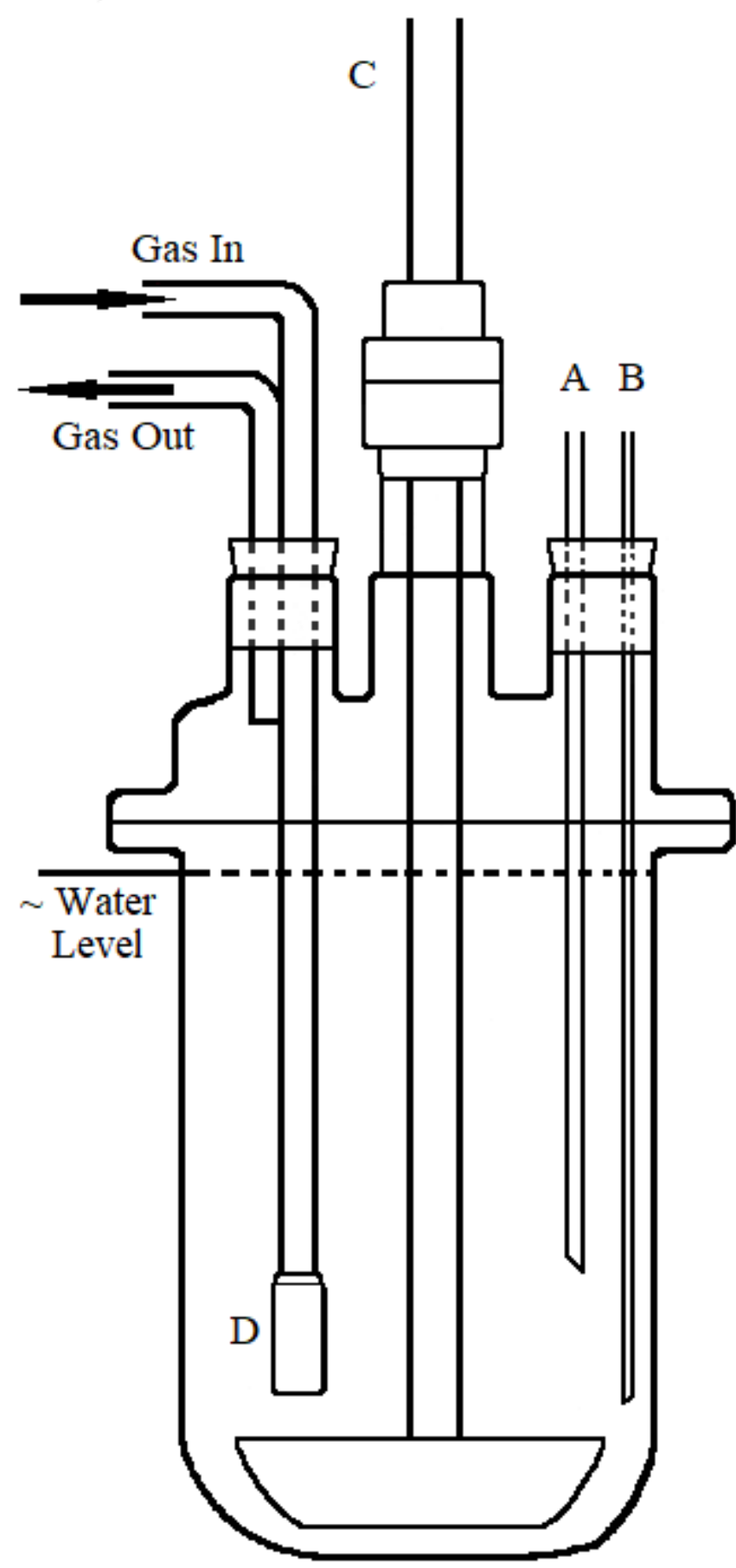

Figure 3.1: Side cut through sketch of the reaction vessel. A. Large diameter tube used to extract samples from inside reaction chamber. B. Fine diameter tubing used to inject ferrous ammonium sulfate solution in the chamber to supply starting material. C. Stirrer assembly maintains the homogeneity of the iron sulfides solution. D. Fine mist bubbler used to saturate DDD water with hydrogen sulfide gas. Excess gas leaves through the glass tube into scrubber solutions. Modified from Murowchick and Barnes 1986. 


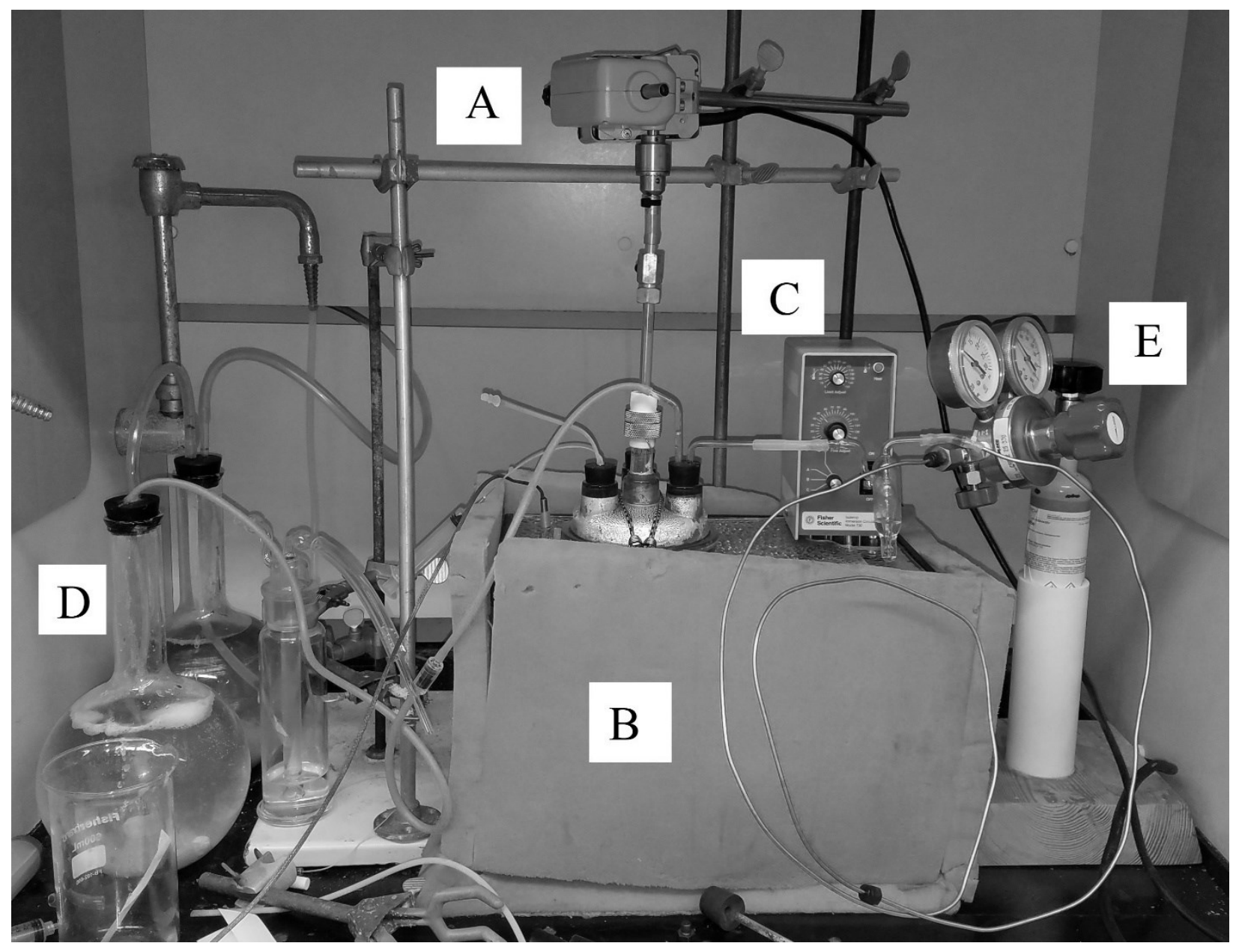

Figure 3.2: Experimental synthesis FeS apparatus. A) Stirrer motor attached to glass stirrer with Teflon seals. B) 10-gallon tank filled with water and surrounded with insulating foam for temperature control. C) Immersion Circulator used for maintaining the desired temperature inside the reaction vessel. D) Zinc acetate/zinc chloride $\mathrm{H}_{2} \mathrm{~S}$ scrubbers. E) Hydrogen sulfide gas source. 


\section{CHAPTER 4}

\section{RESULTS}

Aqueous $\mathrm{Fe}^{2+}$ and $\mathrm{H}_{2} \mathrm{~S}$ were successfully used to synthesize a variety of iron sulfides, including initially-formed mackinawite (tetragonal FeS). Dissolved hydrogen sulfide $\left(\mathrm{H}_{2} \mathrm{~S}\right)$ reacted with aqueous $\mathrm{Fe}^{2+}$ starting to form mackinawite $\left(\mathrm{FeS}_{\mathrm{m}}\right)$, pyrite $\left(\mathrm{FeS}_{2}\right)$, and greigite $\left(\mathrm{Fe}_{3} \mathrm{~S}_{4}\right)$ as major phases, pyrrhotite $\left(\mathrm{Fe}_{1-\mathrm{x}} \mathrm{S}\right)$, smythite $\left(\mathrm{Fe}_{9} \mathrm{~S}_{11}\right)$ and marcasite $\left(\mathrm{FeS}_{2}\right)$ as minor phases. Mackinawite ripened to pyrite by reactions passing through metastable phases.

\section{XRD and Quantitive Analysis}

Reactions at $23,50,70$, and $90^{\circ} \mathrm{C}$ were run for $4080,5520,1805$ and 520 minutes, respectively (table 4.1). Both $23^{\circ} \mathrm{C}$ and $50^{\circ} \mathrm{C}$ reactions maintained mackinawite as the dominant phase for the first 90 minutes, at which time the conversion to greigite/smythite/pyrite began (figure 4.1). The experiment at $23^{\circ} \mathrm{C}$ ended with $\sim 80 \%$ conversion to pyrite, the $50^{\circ} \mathrm{C}$ experiment was stopped at $\sim 42 \% \mathrm{FeS}_{2}$. The $70^{\circ} \mathrm{C}$ and $90^{\circ} \mathrm{C}$ experiments ended with almost $100 \%$ conversion to pyrite. Metastable phases in both 70 and $90^{\circ} \mathrm{C}$ reactions were minor phases which converted rapidly to stable forms of $\mathrm{FeS}_{2}$ or pyrrhotites. The estimated relative error of the PXRD analyses was calculated to be 12-17 wt. $\%$ depending on the reaction temperature, with greater uncertainty for the higher temperature experiments.

Experiments without the presence of formaldehyde showed growth from mackinawite to pyrite with intermediary phases, smythite, greigite, and marcasite; small amounts of pyrrhotites were observed. The mackinawite nucleates throughout the experiment at a linear rate, while greigite abundance correlates with the amount of available mackinawite; both 
reaching a near constant growth rate (figure 4.2). Smythite is seen early in the low temperature $\left(23-50^{\circ} \mathrm{C}\right)$ experiments before the presence of greigite nucleation reaches the near linear nature (figure 4.3). After this point, the smythite is still available but in smaller quantities. Lastly, mackinawite abundance begins to drop while the relative amounts of pyrite and greigite increase until experiment completion. At 70 and $90^{\circ} \mathrm{C}$, smythite is not seen in the analysis due to smythite's upper stability limit of $65^{\circ} \mathrm{C}$.

The products of experiments with formaldehyde at all temperatures did not include pyrite above background levels. Greigite was detected for the duration of the experiments at all the run temperatures. Though greigite was present, mackinawite was the most abundant phase throughout all the reactions.

One experimental complication arose as formaldehyde reacts with ammonium (from the ferrous ammonium sulfate used as a source of $\mathrm{Fe}^{2+}$ ) to form a sticky, resinous material enclosing the iron sulfide starting material. Replacement of ferrous ammonium sulfate with ferrous sulfate in the subsequent experiments eliminated the formation of the undesired resin.

\section{Visual Analysis - SEM}

SEM Images collected of experiments without organics revealed bladed and tabular crystals (figure 4.4). These bladed and tabular crystals formed at 240 minutes at $50^{\circ} \mathrm{C}$; cubic minerals also observed at 240 minutes (figure 4.5). Crystal growth of acicular or possibly filamentous grains with a central core also occurred (figure 4.6). As a sheet mineral, mackinawite could form a chrysotile-like structure, filamentous rolls of wound up mineral. Later visual images show the growth of similar textures and forms continuing only as larger grains. The crystals with a bladed nature are either twinning or an isometric mineral growing from all three axes (figure 4.7). Sparse amounts of orthorhombic grains occurred as well 
(figure 4.8), possibly grains of marcasite. Bladed and acicular crystals clustered around iron sulfates that formed from the starting solution (Mohr's salt) at 23 and $50^{\circ} \mathrm{C}$. With continued ripening, the number of iron sulfide crystals around the starting material increased. These crystal clusters took on a framboid-like structure (figure 4.9). These clusters exhibit a bladed or acicular structure radiating from a central core. With ripening, sparse amounts of cubes accompanied these clusters of bladed and acicular crystals (figure 4.10).

Images of samples taken during experiments doped with formaldehyde exhibit amorphous behavior for much of the reactions (figure 4.11) at all temperatures experimented. After 260 minutes small balls of cubes can be observed in randomly across the amorphous material (figure 4.12 ) in $23^{\circ} \mathrm{C}$ experiments. 

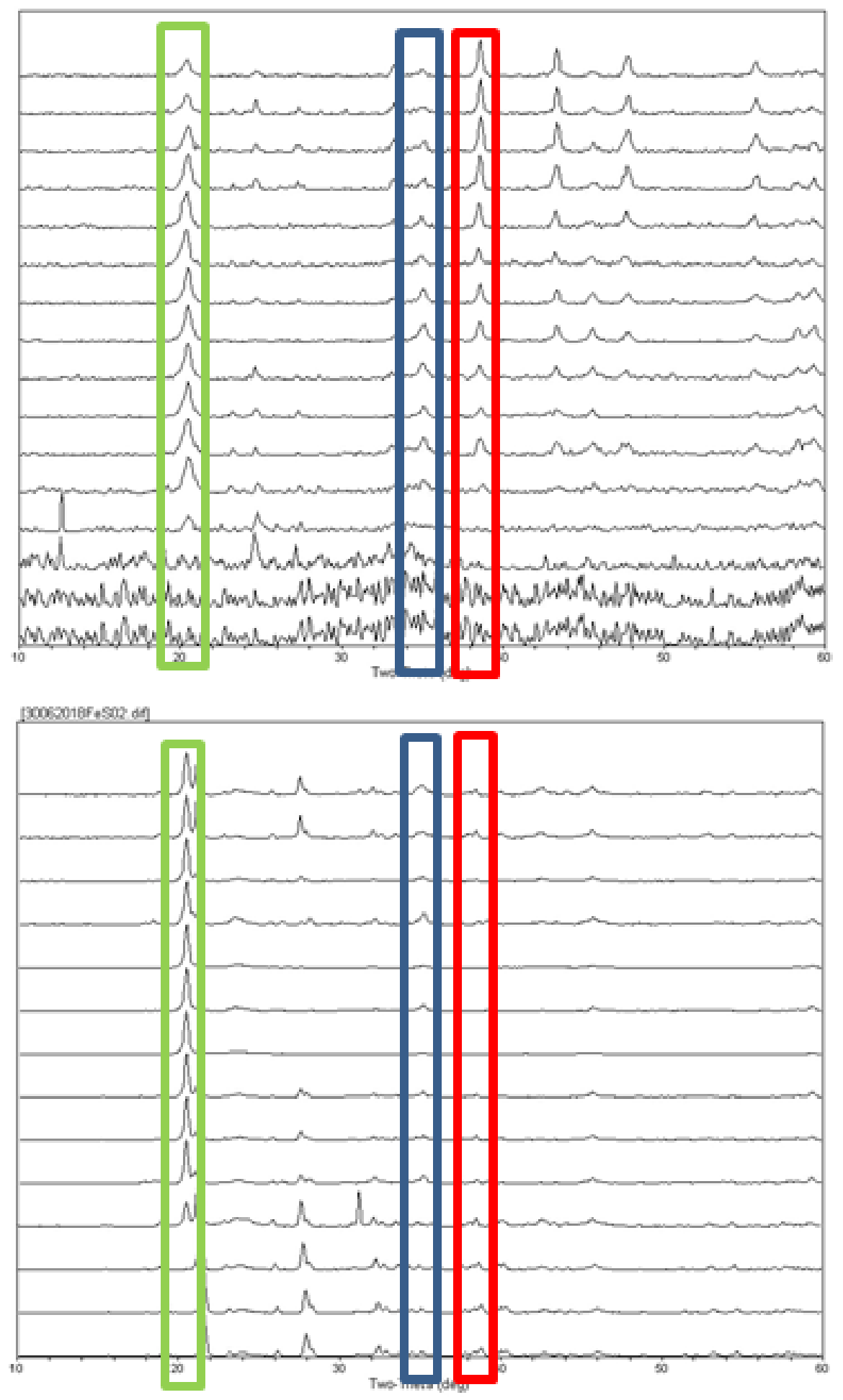

Figure 4.1: Stacked XRD patterns of $50^{\circ} \mathrm{C}$; (top) without organics added; (bottom) with organics. Time increases from 60 minutes to 3360 minutes; bottom to top respectively. Mackinawite main peak on fair left (green) decreases with time, while pyrite main peak (red) increases. Greigite (blue) abundances increase and decrease throughout both experiments. 
Table 4.1: Table of iterations of experiments. Organic-doped runs received $4.8 \mathrm{~mL}$ of formalin (37.5\% formaldehyde). 2 iron atoms per $\mathrm{CHOH}$ molecule was found to be ideal ratio for greigite stability and pyrite inhibiting (Rickard et al., 2001).

\begin{tabular}{|l|l|l|l|l|l|}
\hline Run ID & $\begin{array}{l}\text { Temp Formalin Time Ended Mols of } \\
\left({ }^{\circ} \text { C) }\right.\end{array}$ & Added & $($ min) & Starting Fe & Fe:CHOH \\
\hline 09042018 & 50 & No & 5519 & 0.103 & N/A \\
\hline 17042018 & 23 & No & 1902 & 0.102 & N/A \\
\hline 25042018 & 23 & Yes & 120 & 0.101 & 1.38 \\
\hline 08062018 & 50 & Yes & 60 & 0.102 & 1.39 \\
\hline 20062018 & 50 & Yes & 10 & 0.101 & 1.37 \\
\hline 22062018 & 70 & Yes & 480 & 0.103 & 1.40 \\
\hline 30062018 & 50 & Yes & 5569 & 0.138 & 1.88 \\
\hline 07072018 & 23 & Yes & 4110 & 0.131 & 1.78 \\
\hline 12072018 & 90 & No & 960 & 0.075 & N/A \\
\hline 18072018 & 70 & No & 2805 & 0.075 & N/A \\
\hline 24072018 & 70 & Yes & 473 & 0.088 & 1.19 \\
\hline 18092018 & 90 & No & 520 & 0.075 & N/A \\
\hline 20092018 & 70 & No & 1805 & 0.074 & N/A \\
\hline 29092018 & 70 & Yes & 480 & 0.108 & 1.47 \\
\hline
\end{tabular}




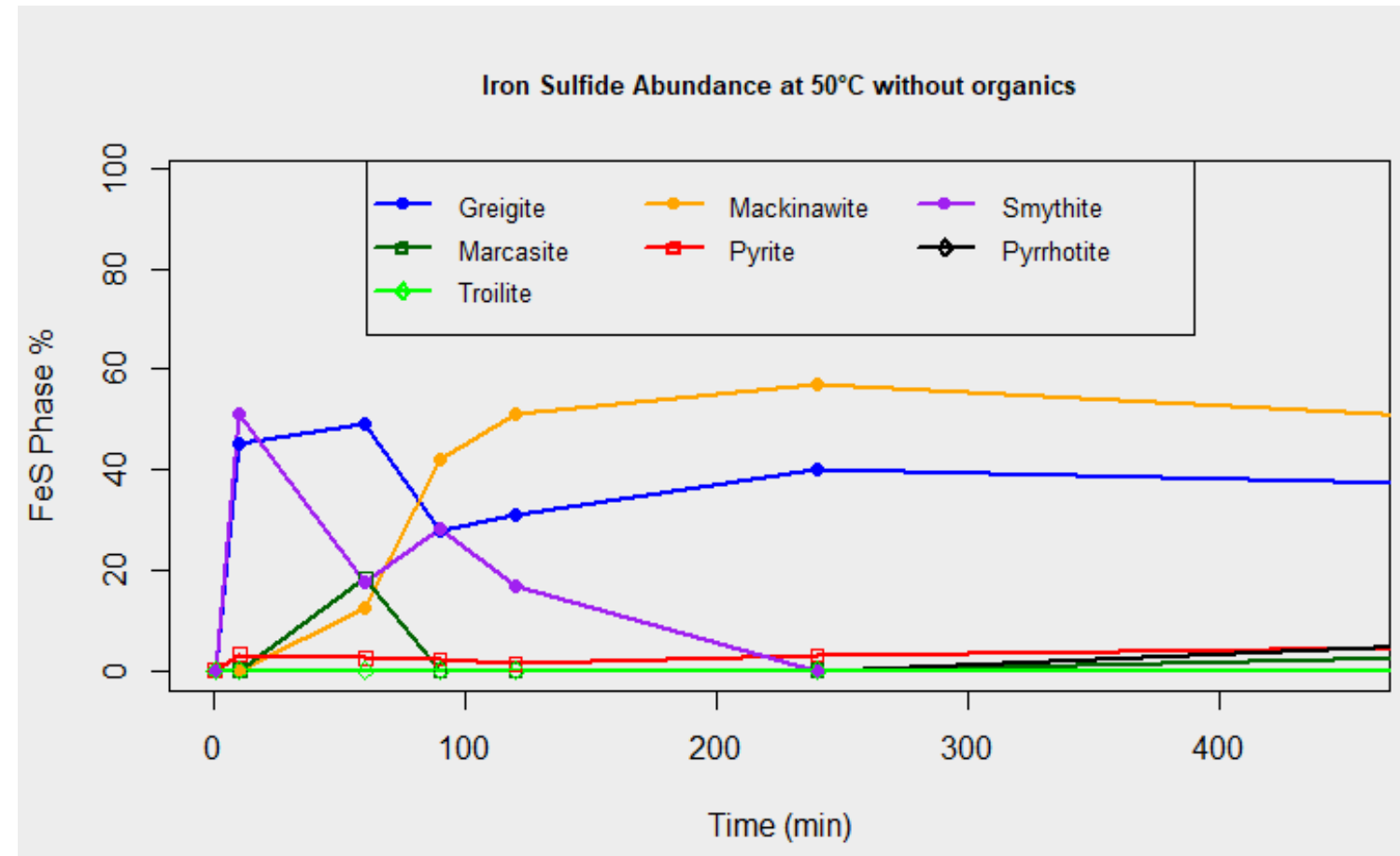

Figure 4.2: Iron sulfide phase percentage at $50^{\circ} \mathrm{C}$ without organics added. Charts display percentage of each phase versus time. Metastable phases immediately develop. Smythite immediately develops which is replaced with greigite. X-axis shortened to 480 minutes in order to emphasize early experiment iron sulfide phase abundance 


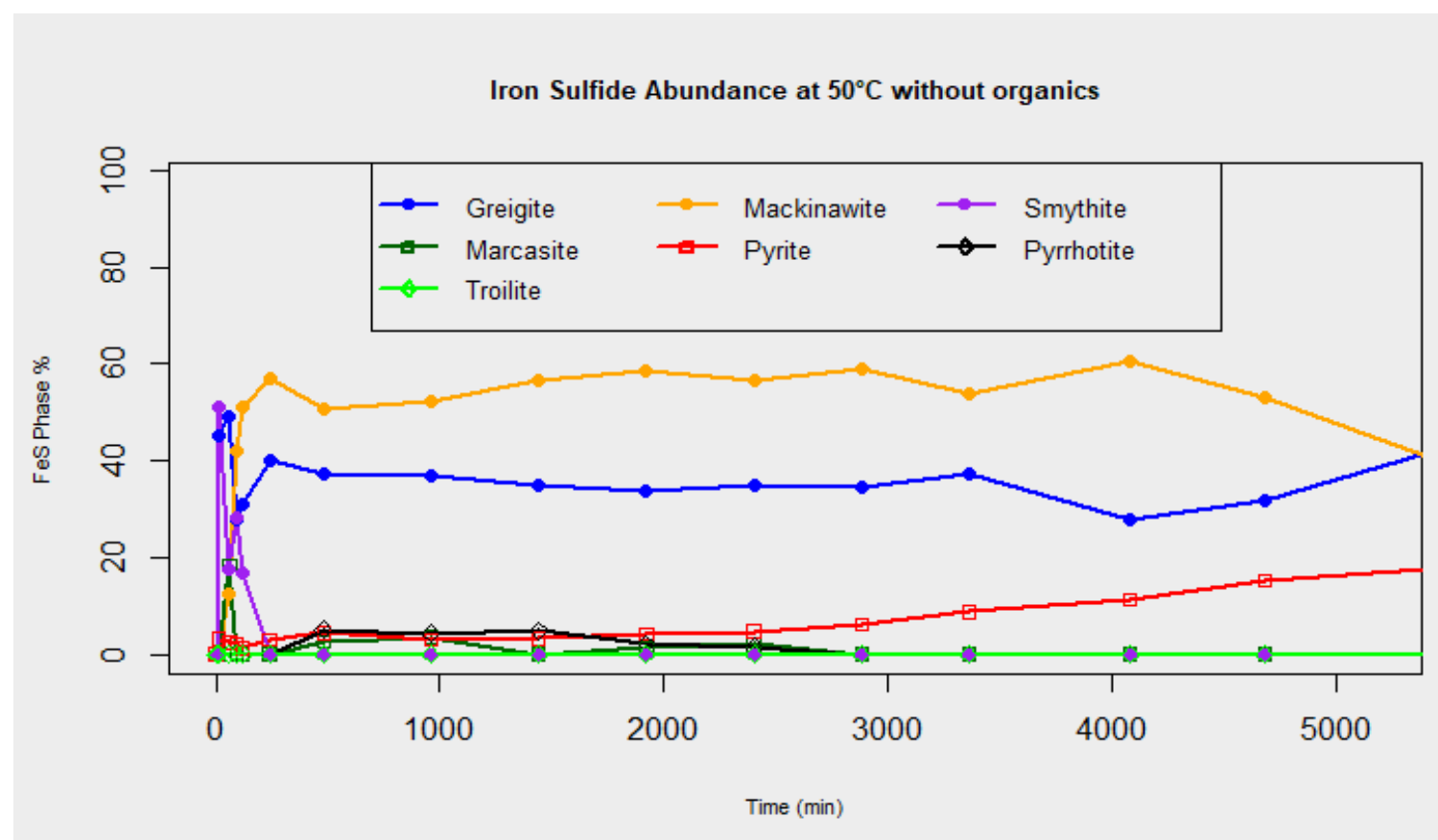

Figure 4.3: Iron sulfide phase percentage at $50^{\circ} \mathrm{C}$ without organics added. Charts display percentage of each phase versus time. Greigite and mackinawite formation appear in unison, when greigite increases, mackinawite decreases. With ripening, mackinawite phase abundances begins to drop while pyrite peak increases at 4000 minutes. 


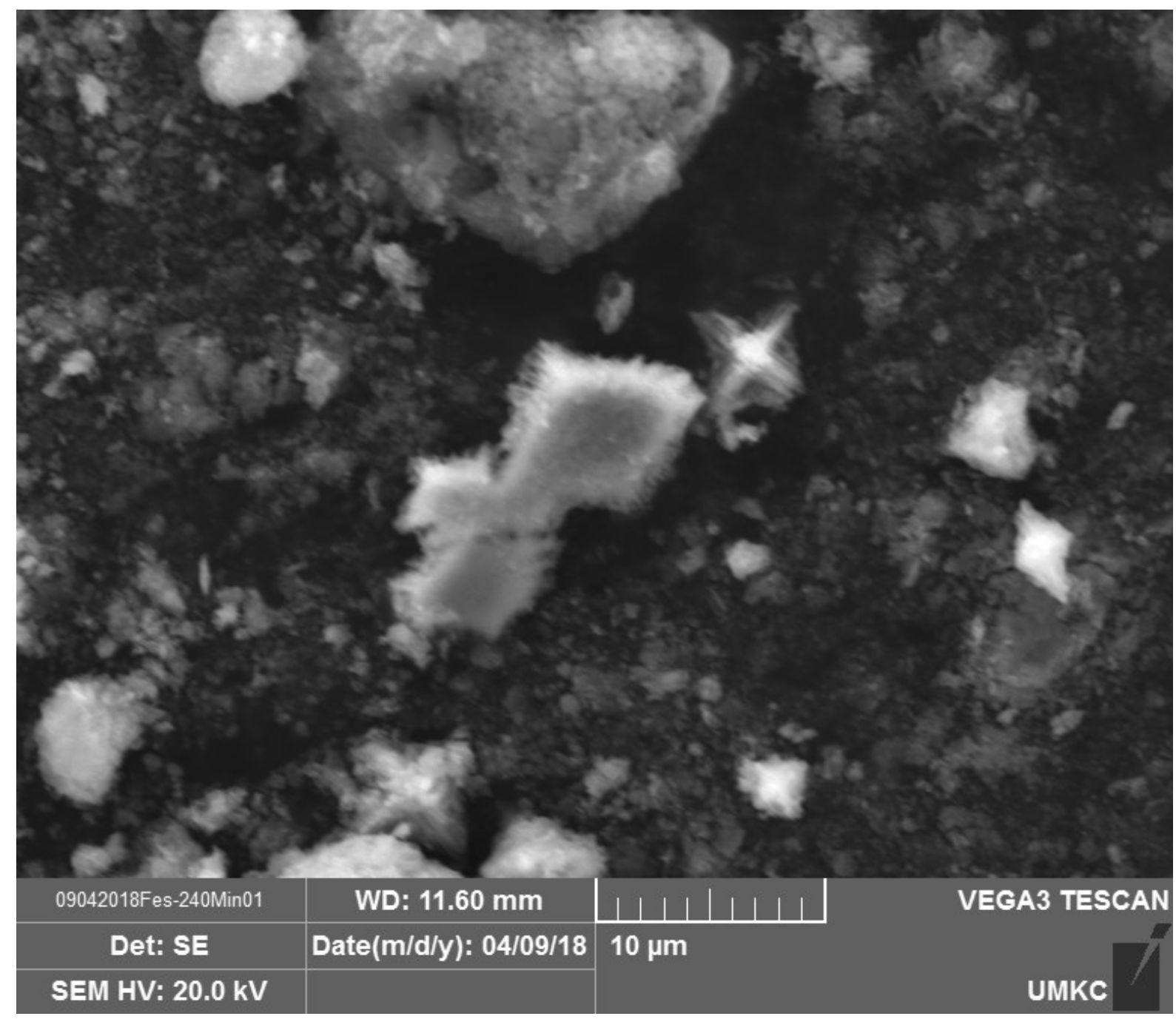

Figure 4.4: SEM Images collected of experiments without organics revealed bladed and tabular crystals. The bladed and tabular crystals formed at 240 minutes at $50^{\circ} \mathrm{C}$. 


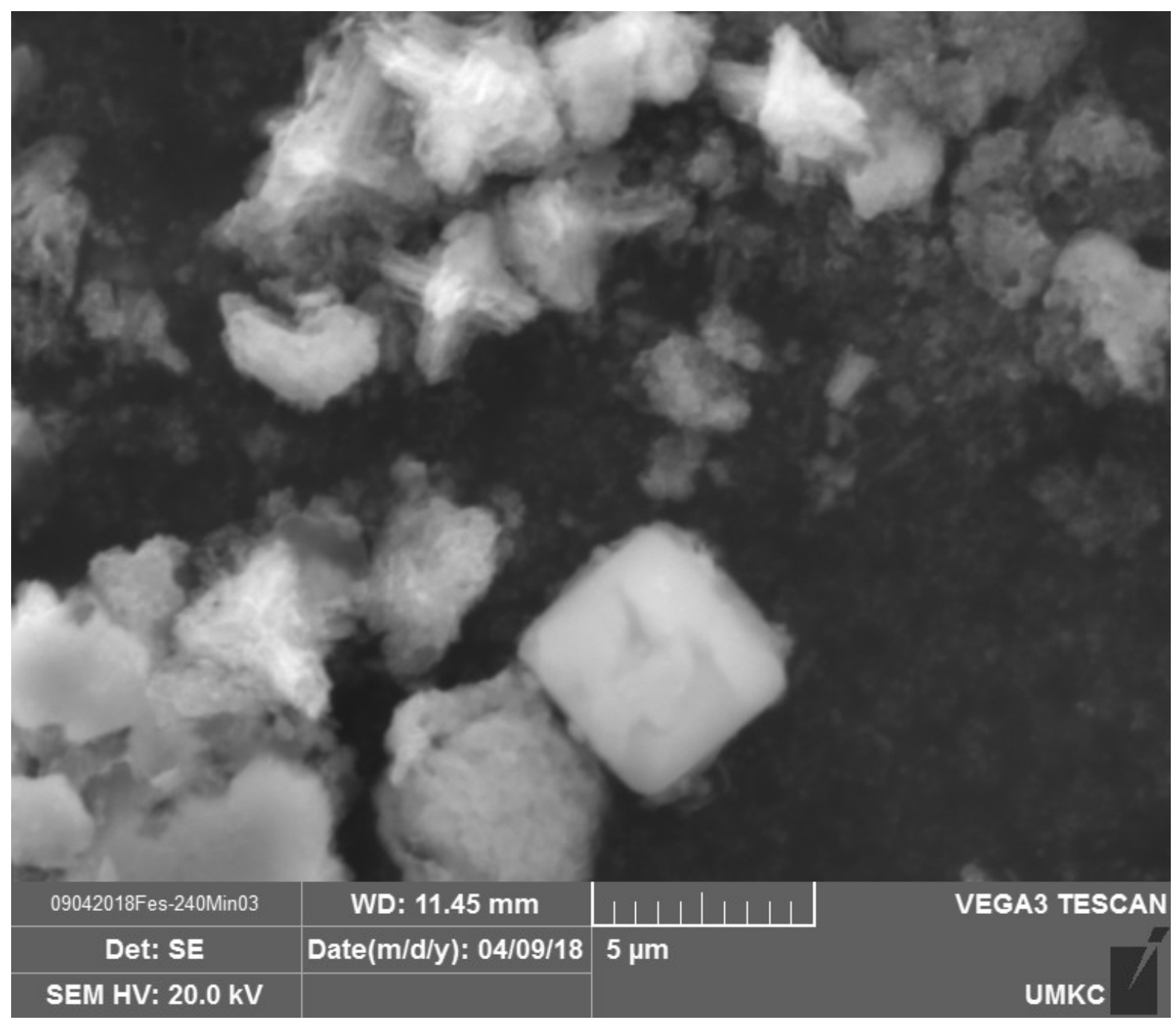

Figure 4.5: SEM Images collected of experiments without organics revealed bladed skeletal octahedra (probably greigite) and cubic crystals (probably pyrite). The bladed and cubic crystals formed at 240 minutes at $50^{\circ} \mathrm{C}$. 


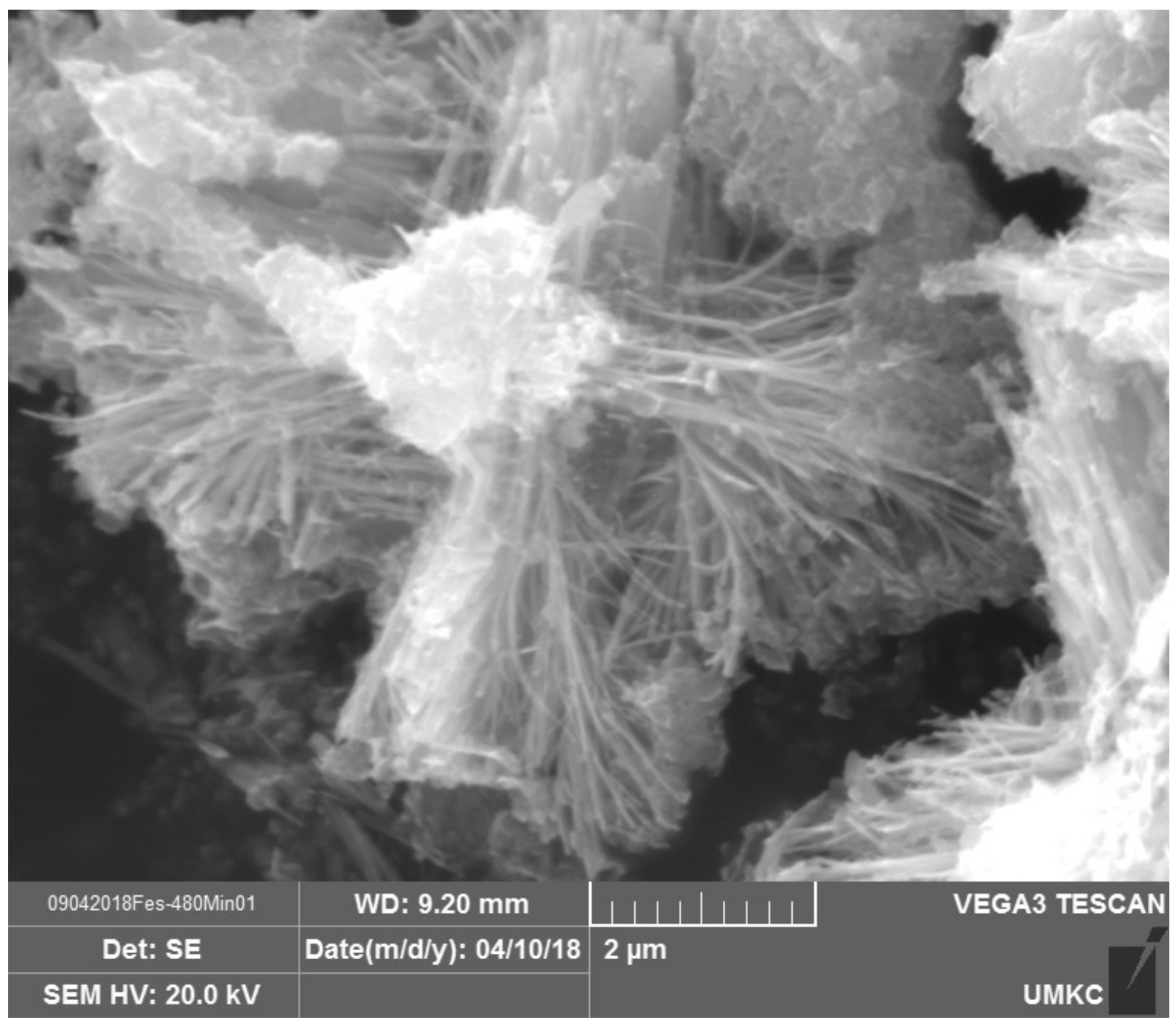

Figure 4.6: SEM Images collected of experiments without organics revealed crystal growth of skeletal octahedra grains with a central core also occurred around 480 minutes at $50^{\circ} \mathrm{C}$. This texture is possibly a result of screw dislocation growth into a brush-like arrangement. The large available surface area of the grain provides lot of area for pyrite conversion. 


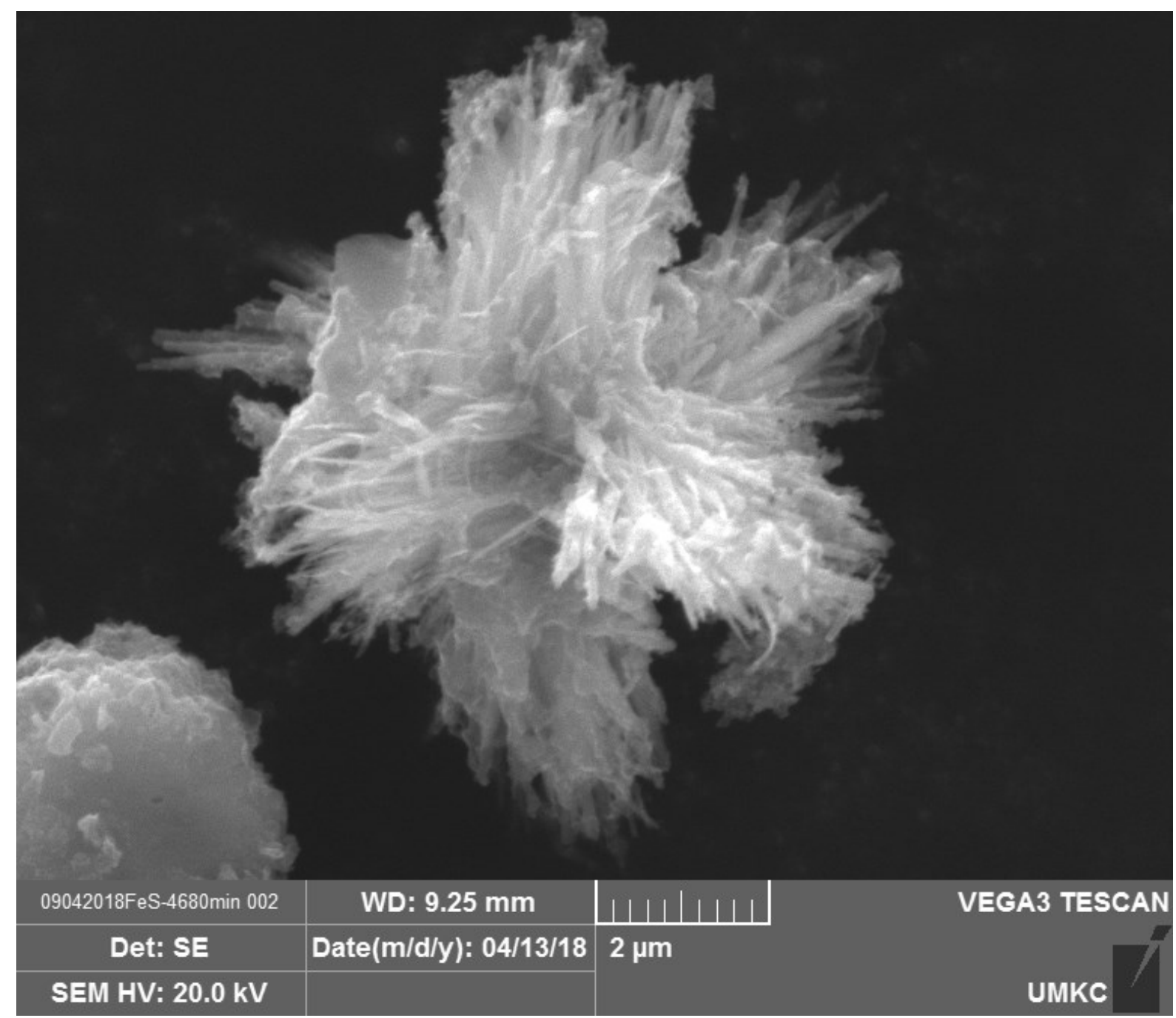

Figure 4.7: SEM Images collected of experiments without organics revealed crystal growth with a bladed nature are either twinning or an isometric mineral growing from all three axes. This growth is probably a more mature version of filamentous skeletal octahedra previously seen. Image taken after 4680 minutes of ripening at $50^{\circ} \mathrm{C}$. 


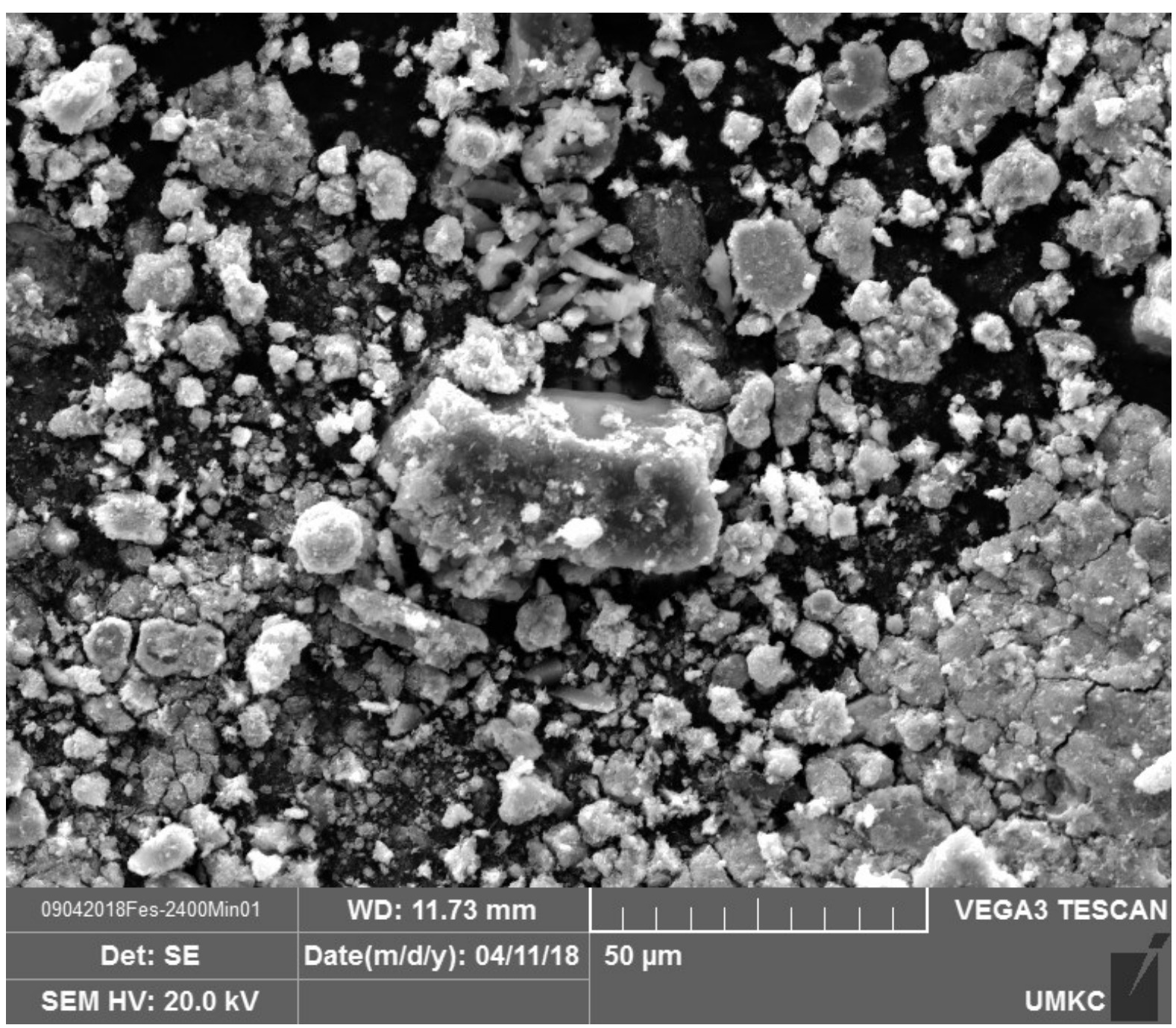

Figure 4.8: SEM Images collected of experiments without organics revealed crystal growth Sparse amounts of orthorhombic grains occurred as well. Image taken after 2400 minutes of ripening at $50^{\circ} \mathrm{C}$. 


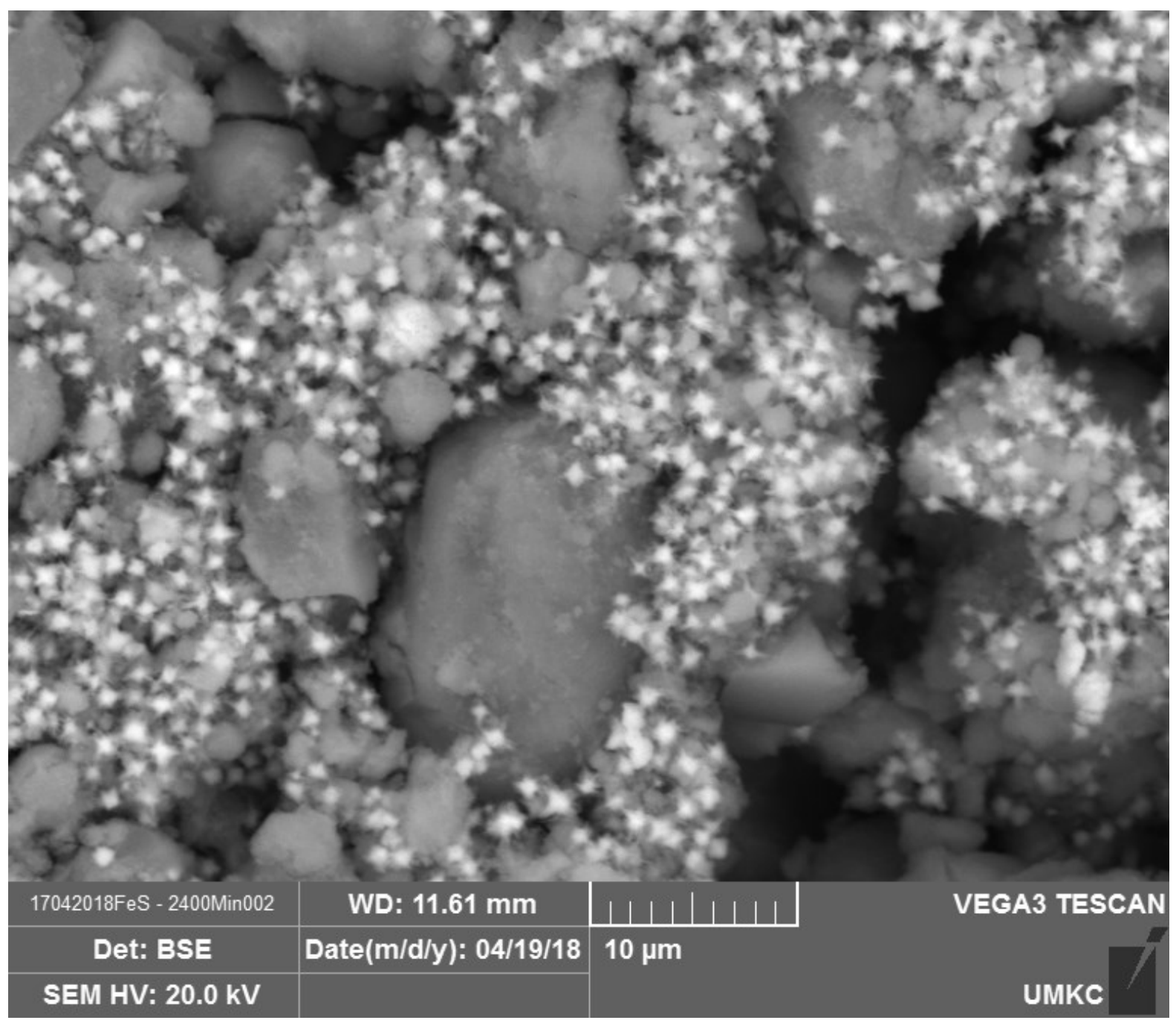

Figure 4.9: Crystals clustered around iron sulfates that formed from the starting solution (Mohr's salt). Around these iron sulfate crystals large numbers of crystals formed, similarly to a framboid. These clusters exhibit a bladed or acicular structure radiating from a central core; probably skeletal octahedra of greigite. 


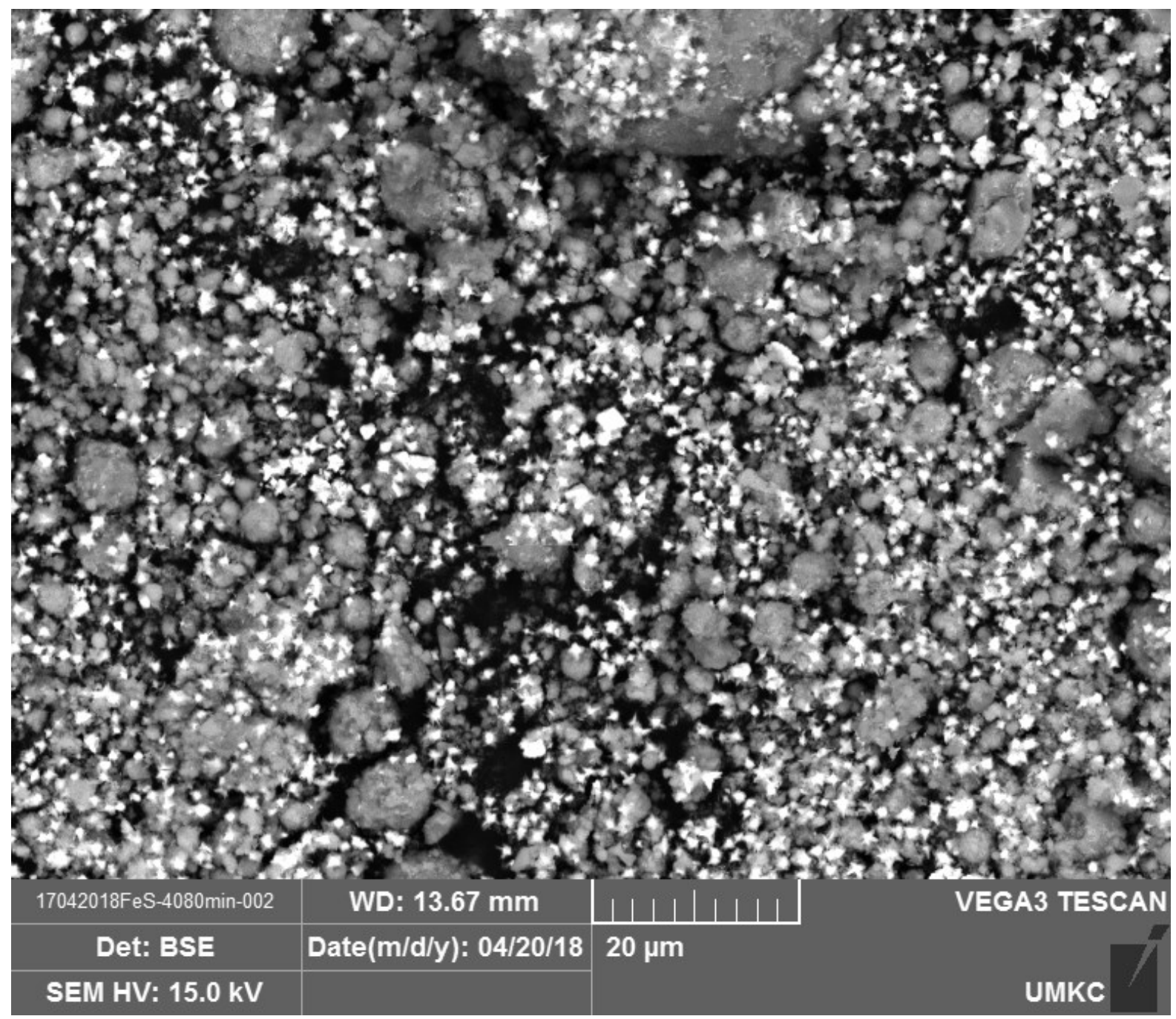

Figure 4.10: Crystals clustered around iron sulfates that formed from the starting solution (Mohr's salt). Around these iron sulfate crystals large numbers of crystals formed, similarly to a framboid. These clusters exhibit a bladed or acicular structure radiating from a central core; probably skeletal octahedra of greigite. With ripening, sparse amounts of cubes accompanied these clusters of blades. 


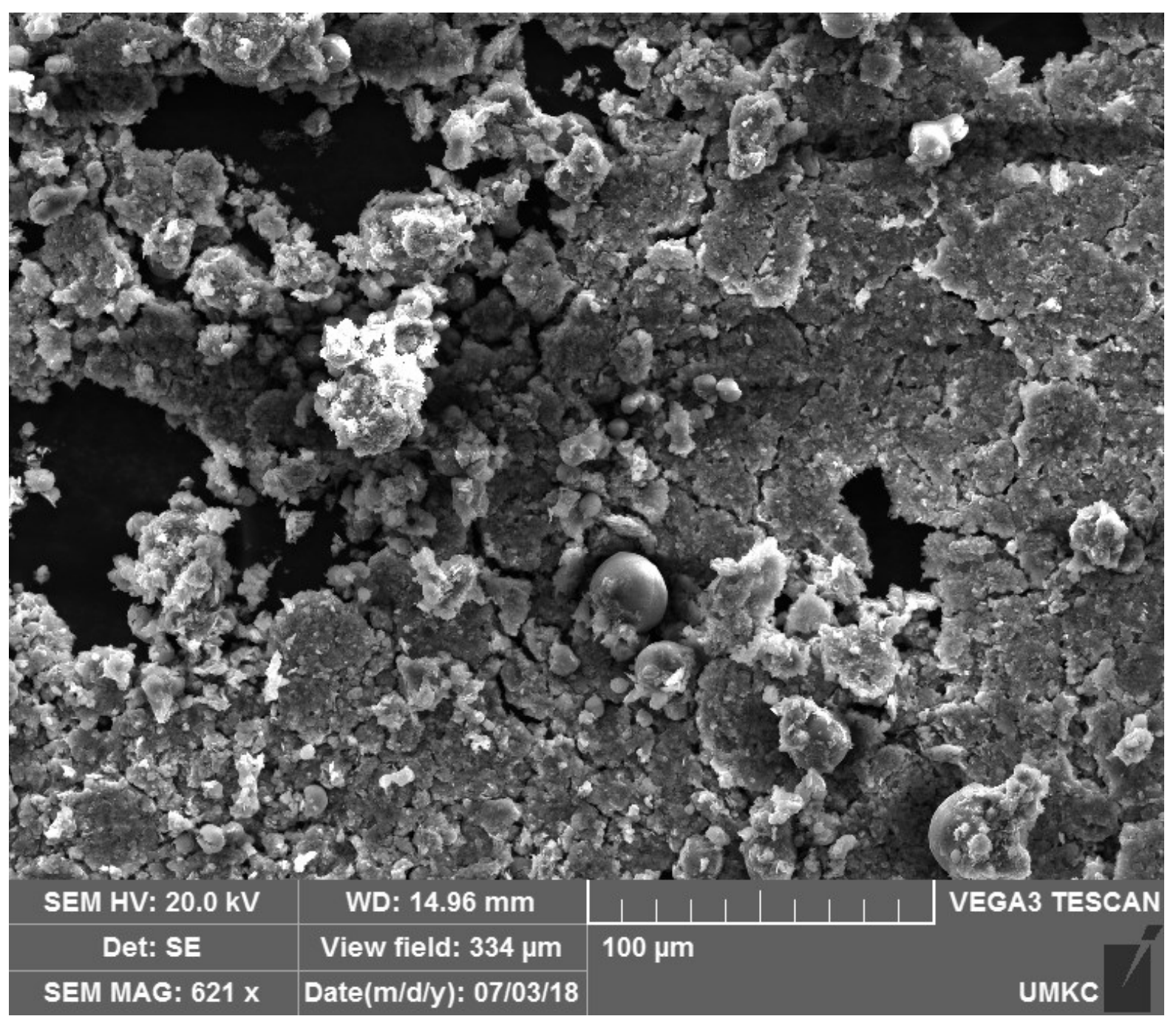

Figure 4.11: Images of samples taken during experiments doped with formaldehyde exhibit amorphous behavior for much of the reactions. Image taken after 4070 minutes of ripening at $50^{\circ} \mathrm{C}$. Crystal maturity is not as progressed as runs without formaldehyde. 


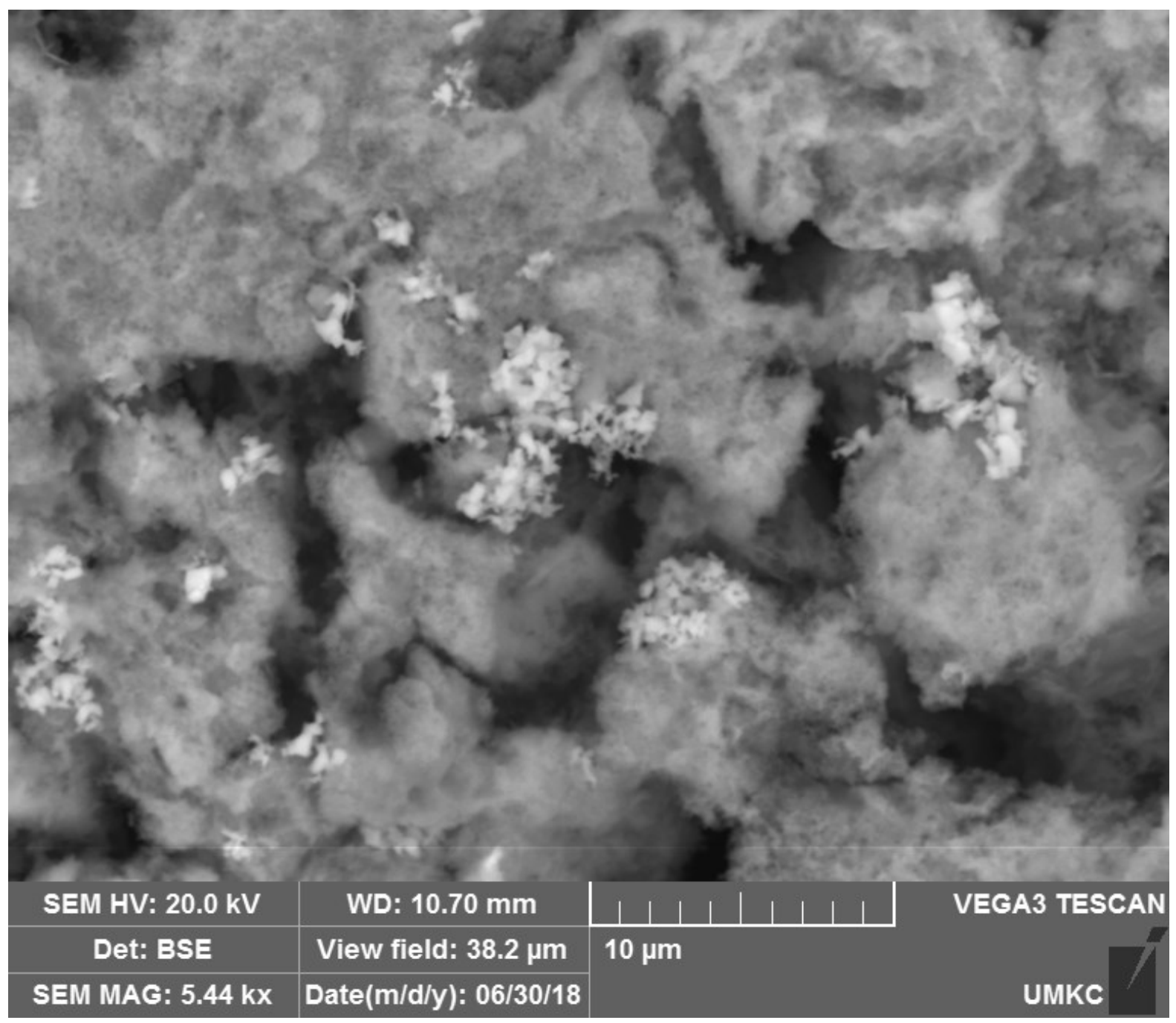

Figure 4.12: After 260 minutes of ripening at $23^{\circ} \mathrm{C}$ in the presence of aldehydes, small balls of cubes can be observed in randomly across the amorphous material. 


\section{CHAPTER 5}

\section{DISCUSSION}

\section{JMAK Equation Transformation Kinetics}

Kolmogorov originally derived the Johnson-Mehl-Avarmi-Kolmogorov equation, though through a series of popular articles released by Avarmi this equation to date is known as the Avarmi equation. The equation is applied for solid-state transformations in each a parent phase is converted fully to a daughter phase (Rimstidt, 2013) (Eq 1).

$$
X(t)=1-\exp [-\kappa(T \Delta G)] \cdot t^{n}
$$

Before the Johnson-Mehl-Avarmi-Kolmogorov (JMAK) equation can be applied three assumptions must be made: 1. The solid-state transformation occurs through random and homogeneous nucleation such that the nucleation sites are filled randomly, however, the sites are evenly distributed amongst the surface or edge of growth. 2. The nucleation rate is constant, this infers that once the product has begun to ripen the rate at which it grows maintains as a linear function. 3. The nucleation rate is constant in all directions; nucleation occurring on multiple surfaces of the parent material is not being done so at different rates. Since assumptions must be made there is still some debate on whether the JMAK can accurately predict solid-state transformations. However, from previous works using the JMAK equation there does seem to be a correlation between the results of the equation the nucleation geometry during the solid-state transformation (Rimstidt, 2013).

Application of experimental data is in the form of $\alpha$, such that $X(t)$ is the experimental volume of parent material transformed as both a function of time and temperature, volume of parent material $(\mathrm{V})$ divided by the total volume of material $\left(\mathrm{V}_{\mathrm{t}}\right)(\mathrm{Eq} 2)$.

$$
\mathrm{X}(\mathrm{t})=\frac{\mathrm{V}}{\mathrm{V}_{\mathrm{t}}}=\alpha
$$


After applying the general assumptions of the equation, the JMAK equation must be converted into a linear function to find the value of ' $n$ ' and $\kappa(E q 3)$. The exponent ' $n$ ' correlates to the nature of the nucleation throughout the solid state transformation; smaller values of 1 and 2 indicate one-dimensional growth indicative of surface growth on two parallel planes, e.g. growth on the (001) plane of sheet mineral. While, an 'n' value of 3 a more twodimensional growth, surface, and edge growth; and an ' $n$ ' value of 4 indicates a threedimensional growth. The variable $\kappa$ is the rate of nucleation, assumed to be controlled by a thermally activated process.

$$
\ln (-\ln (1-\alpha))=\ln (\kappa)+\operatorname{nln}(t)
$$

Plotting equation 3 as the natural log of the time elapsed during transformation ( $\mathrm{x}$-axis) versus $\ln (-\ln (1-\alpha))(y-a x i s)$ produces a linear fit to the experimental data. The trend of the data gives the values of $\kappa$ and $n$ in the form of the $y=m x+b$; such that slope of the line is ' $n$ ' and $b$ is the $\ln (\kappa)$ (figure 5.1). These values can be unique for each temperature thus requiring the equation to be calculated at all temperatures.

Once the all variables have been solved for, implementing the JMAK equation is done through substitution of variables and $\alpha$ from start to finish of the reaction; $\alpha=1$ and $t=0$ through $\alpha=0$. The application of the equation creates a sigmodal plot (figure 5.2). This start and stop of the reactions display an asymptotic nature as the reaction begins and as the reaction slows at decreased activities and limited sites for nucleation.

Experiments without the presence of formaldehyde do produce the expected outcome from the JMAK linear equations (figure 5.3). Experiments from $23-50^{\circ} \mathrm{C}$ resulted in an ' $\mathrm{n}$ ' value of 1; correlating to a one-dimensional surface growth nucleation possibly on the (001) 
plane of mackinawite. At $70^{\circ} \mathrm{C}$, the slope of the JMAK plot moved to 2, indicating the growth was still mostly a surface growth but some edge growth was now involved producing a twodimensional growth. This change could be explained due to smythite no longer being stable above $65^{\circ} \mathrm{C}$ (Krupp, 1994). While the $90^{\circ} \mathrm{C}$ run shows ' $\mathrm{n}$ ' value of 3 indicating a more 3 dimensional growth (figure 5.3). This change in growth may be a product of rapid nucleation resulting in disorders or defects in the structure causing new growth to change from 2dimensional, strictly from (001) planes of mackinawite outwards, to a 3-dimensional growth, growth on (001) plane of mackinawite serves as sites of the rapid growth of pyrite.

However, the $23^{\circ} \mathrm{C}$ experiment exhibited faster ripening kinetics than at $50^{\circ} \mathrm{C}$. This result could be an issue with the application of the JMAK equation in an iron sulfide system. Remembering the three assumptions required to apply the JMAK equation, specifically the assumption that homogeneous nucleation from a parent to a daughter phase, is simply not satisfied. During iron sulfide ripening, multiple pathways can occur at the same time; all those pathways do not end in pyrite. Any material inverted to pyrrhotite would change the volumes converted from starting material. Krupp (1994) suggested that the sulfur lattice of the metastable phases, mackinawite, greigite, and smythite, share the same structure. Irons diffuse with the ripening process, therefore may not be a true solid-state transformation; the sulfur lattice is not broken and/or contorted into a new structure: like in an alpha-beta quartz conversion, or diamond-graphite metastable transformation.

Formaldehyde-doped runs did not exhibit the same transformation kinetics as the experiments without organics. The experimental data did not fit for linear derivation JMAK equation (figure 5.4). The lack of precision may be due to the metastable nature of greigite the relative abundances of greigite increase and decrease throughout the experiment's runtime. Or 
one of the three assumptions required for the JMAK equation to work is not being satisfied; it is likely that the formaldehyde's selective oxidation (Wang et al., 2015) occurs randomly thus interrupting the homogenous and random nucleation on the (001) plane of mackinawite (figure 5.5); two random processes interfering with each other. As stated previously, JMAK equation simply may not be the best approach for iron sulfide ripening kinetics.

\section{Arrhenius Equation}

The Arrhenius calculations for these experiments were based on the ripening of mackinawite to pyrite. Applying the Arrhenius Equation (Eq 4) provides calculations on the energy needed to progress a reaction, known as the activation energy. Activation energy is minimum energy reactant molecules in a reaction must be capable of before a reaction can move towards the products. The Arrhenius equation relates rate constants to the dependency of temperature (Laidler, 1984). Much like the JMAK equation, to determine the unknown variables requires derivation of a linear form of the Arrhenius equation (Eq 5).

$$
\begin{aligned}
& \mathrm{k}=\mathrm{Ae}^{-\mathrm{Ea} / \mathrm{RT}} \\
& \ln \mathrm{k}=\ln \mathrm{A}+\frac{-\mathrm{Ea}}{\mathrm{R}} \cdot \frac{1}{\mathrm{~T}} \\
& \mathrm{k}=\text { rate constant } \\
& \mathrm{R}=\text { gas constant }(8.314 \mathrm{~J} /(\mathrm{mol} \mathrm{K})) \\
& \mathrm{T}=\text { temperature in Kelvin } \\
& \mathrm{A}=\text { collision rate } \\
& \mathrm{Ea}=\text { Activation Energy }
\end{aligned}
$$

Rate constant is the speed in which a reaction occurs, represented in mols/sec. Collision rate numerically represents the changes of two molecules colliding during a reaction in order for 
the reaction to progress. Both the collision rate and rate constant are temperature dependent (Laidler, 1984). Plotting of the linear form of the Arrhenius equation provides a trendline to the experimental data (figure 5.6); the trendline takes of the form of the standard slope equation $y=m x+b$. The slope of the line equals the negative activation energy related to the gas constant $(-\mathrm{Ea} / \mathrm{R})$, and the $\mathrm{y}$-intercept equals $\ln (\mathrm{A})$. Once all variables are accounted for, the exponential form of the equation is then applied to show the change in the rate constant as a product of temperature at a set activation energy (figure 5.7).

Experiments in this study produced rate constants of $1.47 \cdot 10^{-07}, 2.50 \cdot 10^{-06}$, and $2.62 \cdot 10^{-06}(\mathrm{mols} / \mathrm{sec})$ at 50,70 , and $90^{\circ} \mathrm{C}$ respectively; omission of the $23^{\circ} \mathrm{C}$ occurred due to lack of confidence in the data set. Application of the data calculated an activation energy of $63.50( \pm 5.08) \mathrm{kJ} / \mathrm{mol}$. Typically solid state reactions produce an activation energy of 80-320 $\mathrm{kJ} / \mathrm{mol}$ (Hunger and Benning, 2007). However, this activation energy is similar to the ripening of mackinawite to greigite calculated by Hunger and Benning (2007) of $67.5( \pm 10.6)$ $\mathrm{kJ} / \mathrm{mol}$. This low activation energy reaffirms that ripening of iron sulfides may not be a true solid state transformation but rather the diffusion of iron molecules across a sulfur lattice (Krupp, 1994). Despite the low activation energy, the rate constant of the ripening of mackinawite to pyrite increases 22 -fold from $50-100^{\circ} \mathrm{C}$. 


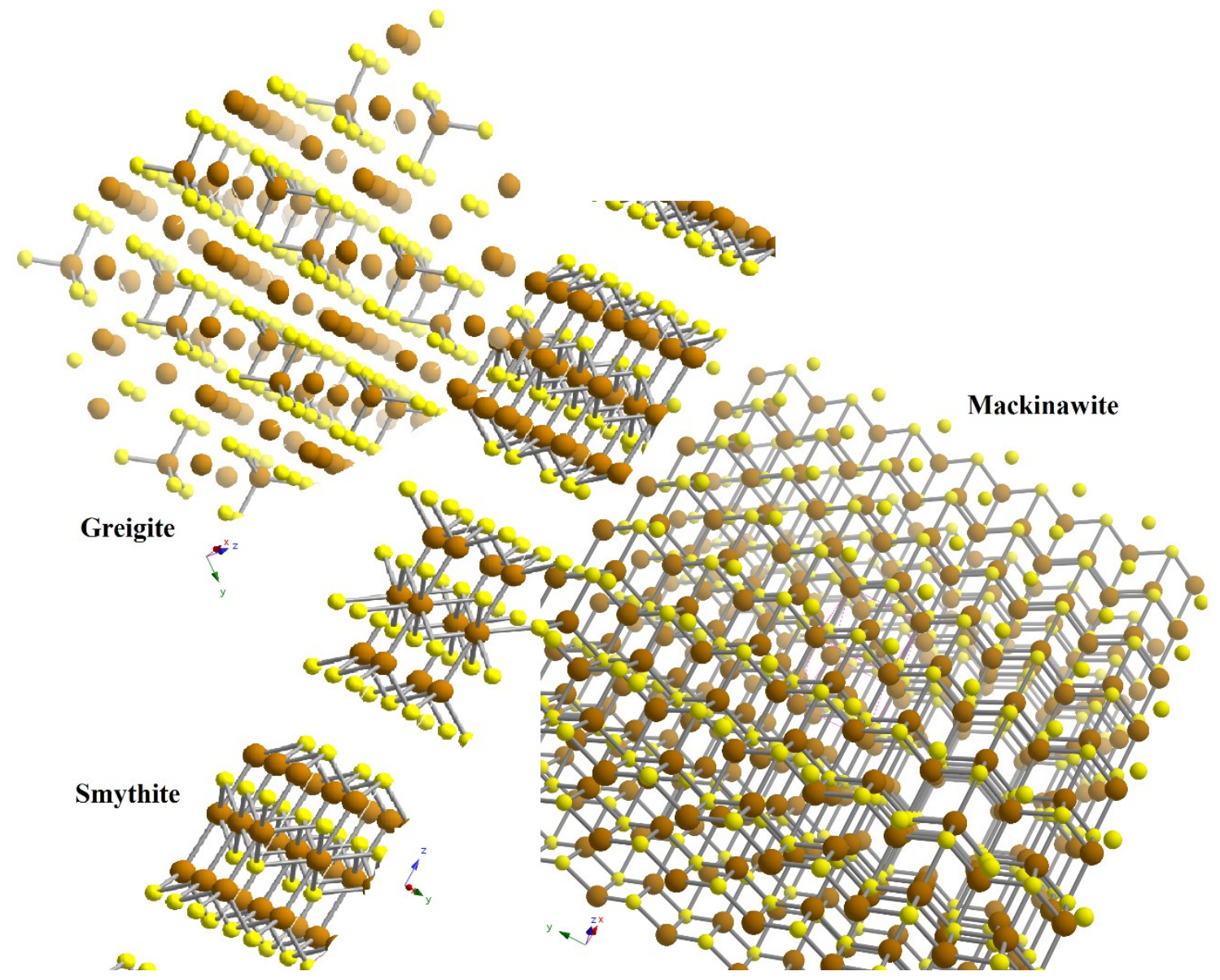

Figure 5.1: Diagram of close packed sulfur arrangement. The smythite, greigite, and mackinawite close packing of sulfurs align to form uniform planes across greigite and mackinawite's (111) plane and smythite's (001) plane. Iron molecules move among the sulfur lattice to form three metastable iron sulfides. Picture modified from Krupp (1994). 

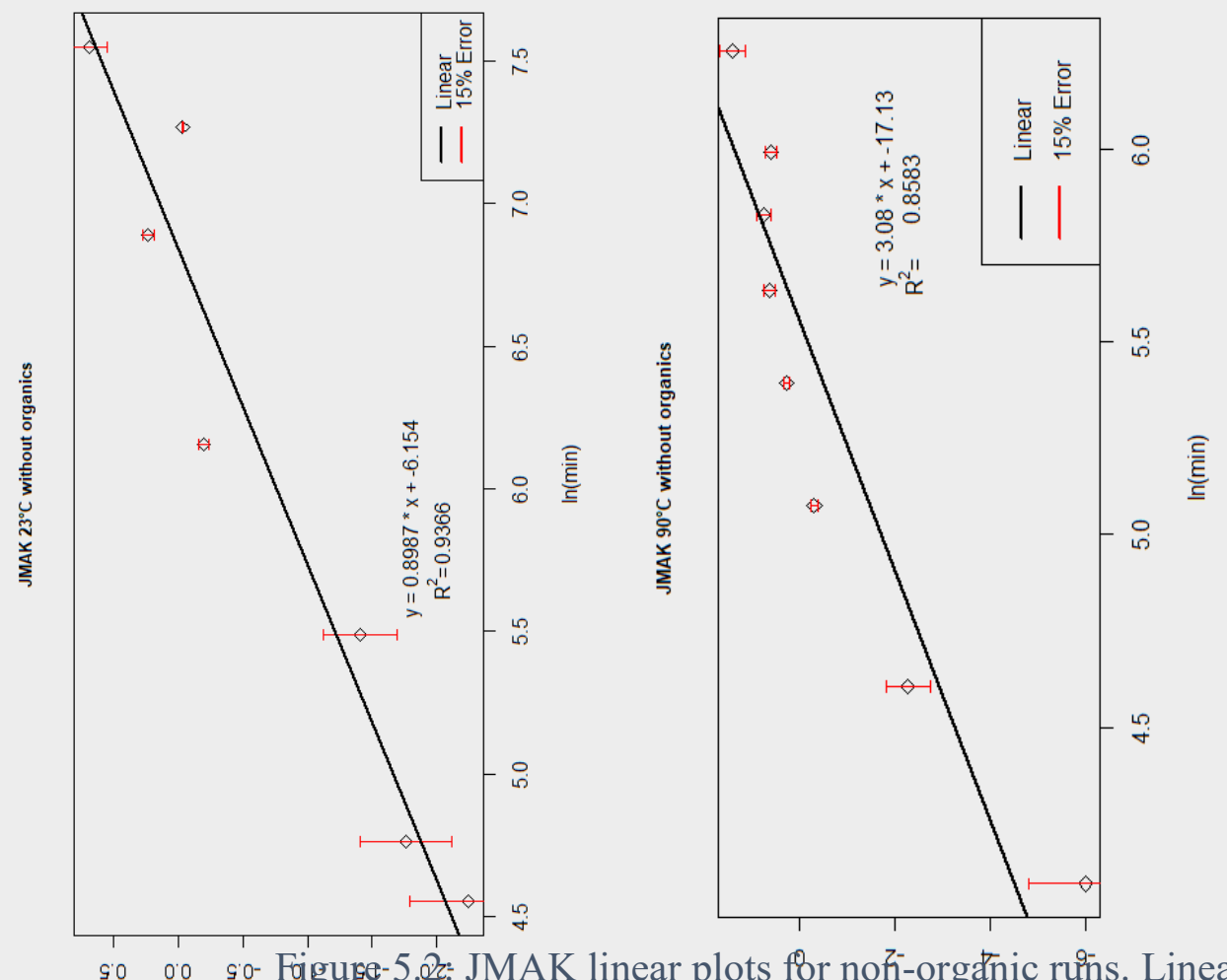

so to so- Faigube-5.2z: JMAK linear plots for nofi-orgănic rưns. Linear plots exhibit a good fit. Linear (erderliseuin full equation.
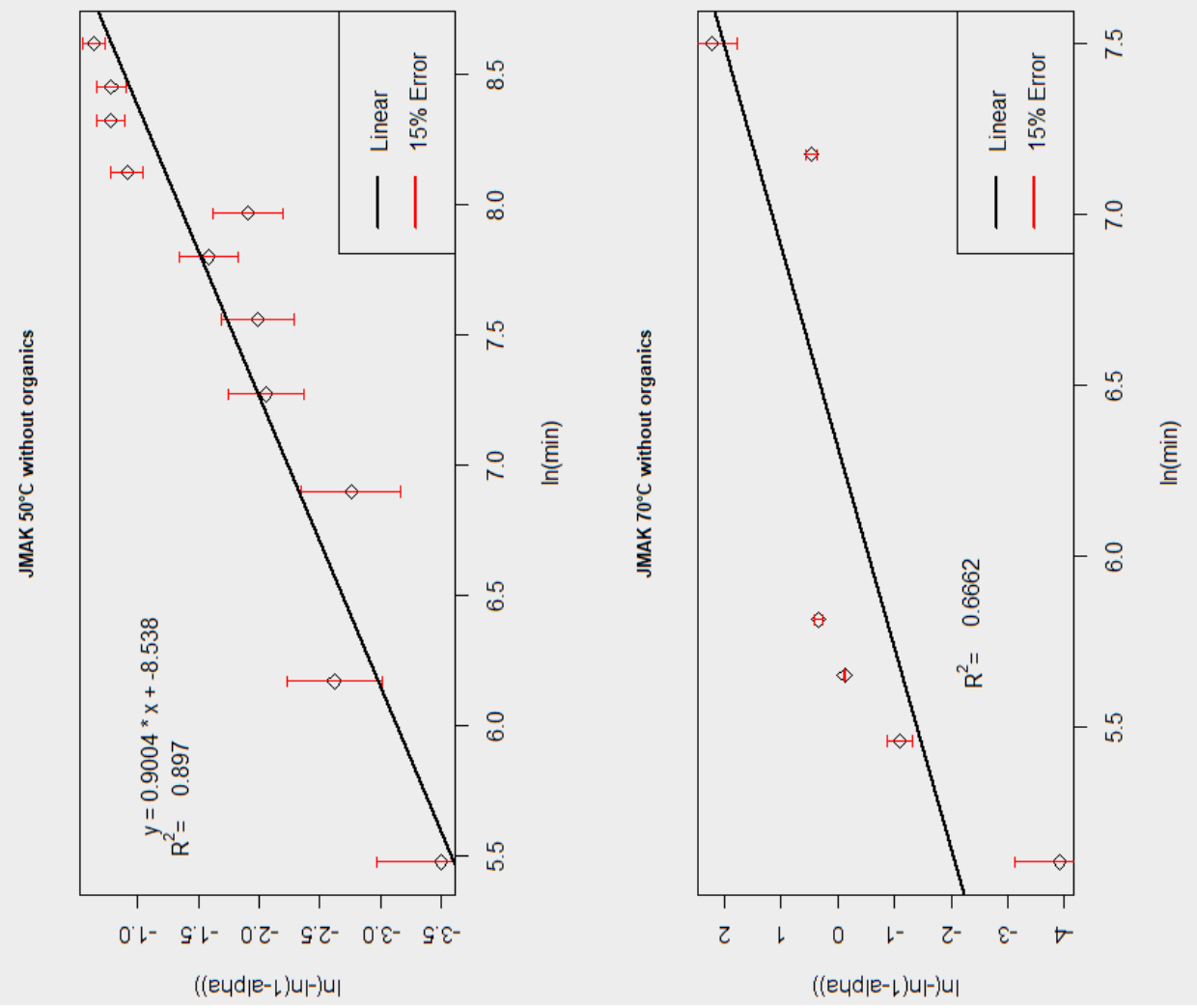


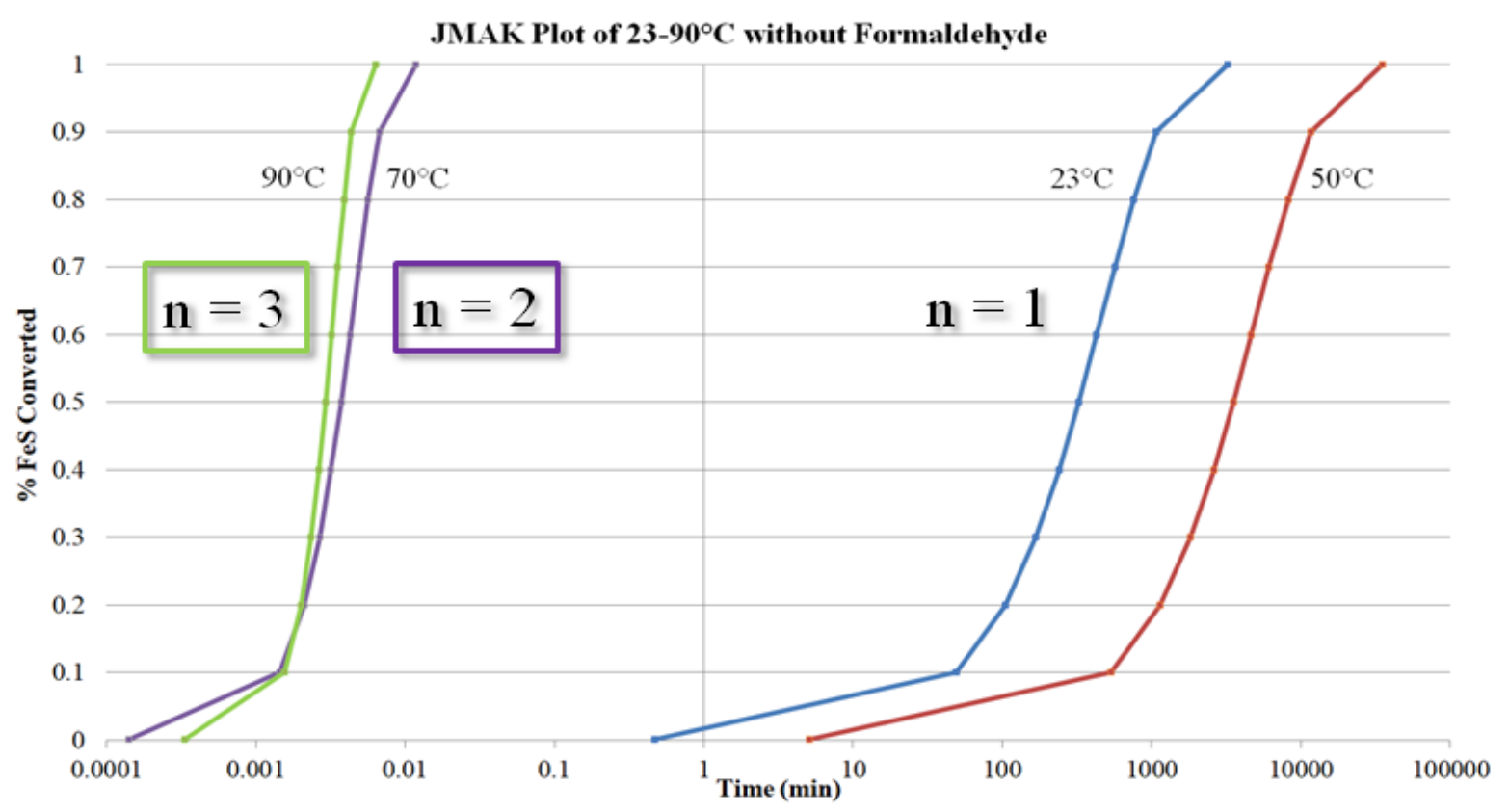

Figure 5.3: JMAK plot of transformation kinetics. 23 and $53^{\circ} \mathrm{C}$ exhibit same $n$ value of 1 indicating a surface growth. $70^{\circ} \mathrm{C}$ has a slope of 2 indicating a surface growth with some edge growth. While at $90^{\circ} \mathrm{C}$ the slope becomes 3 indicating a more spherical growth. 


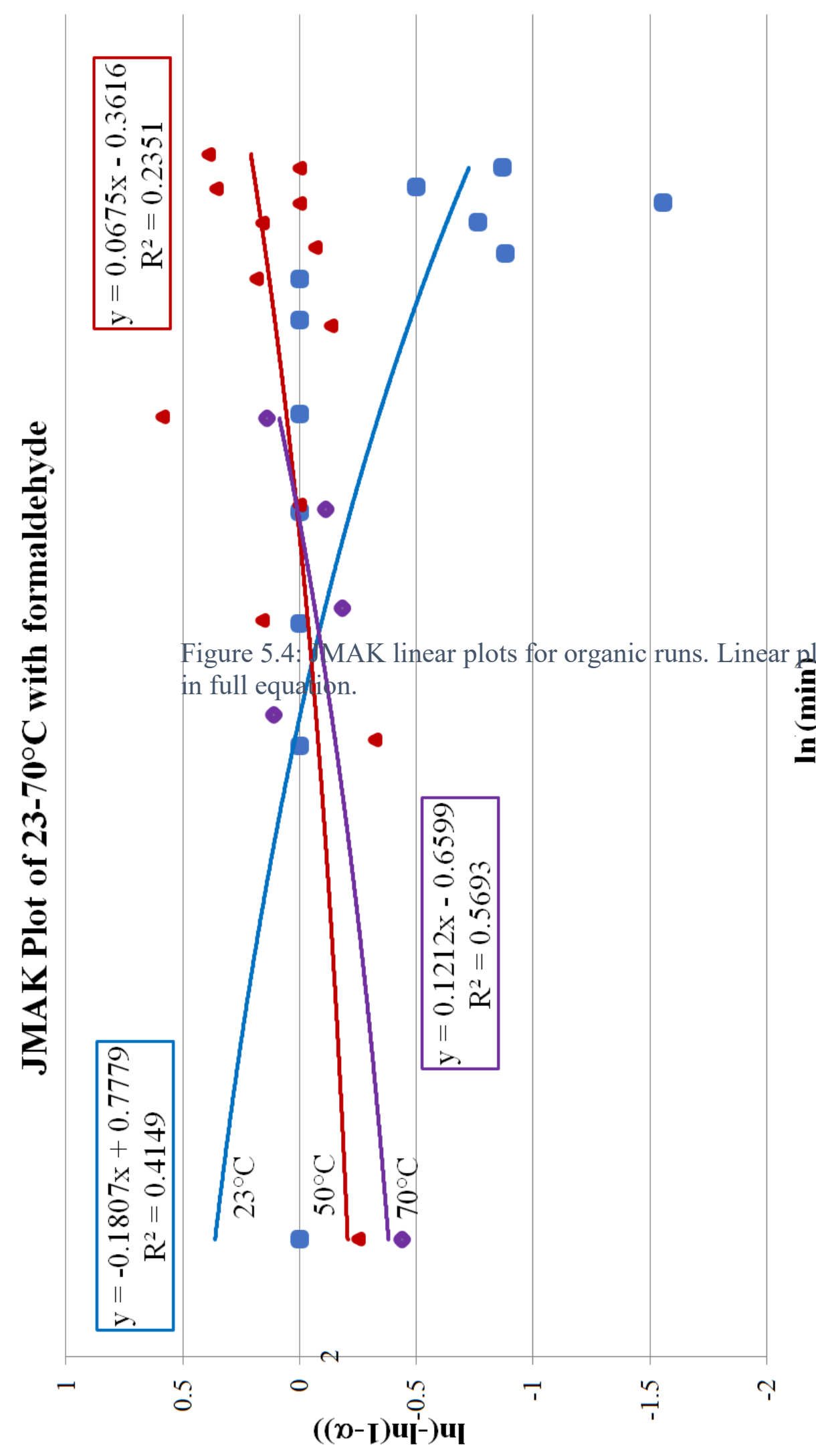




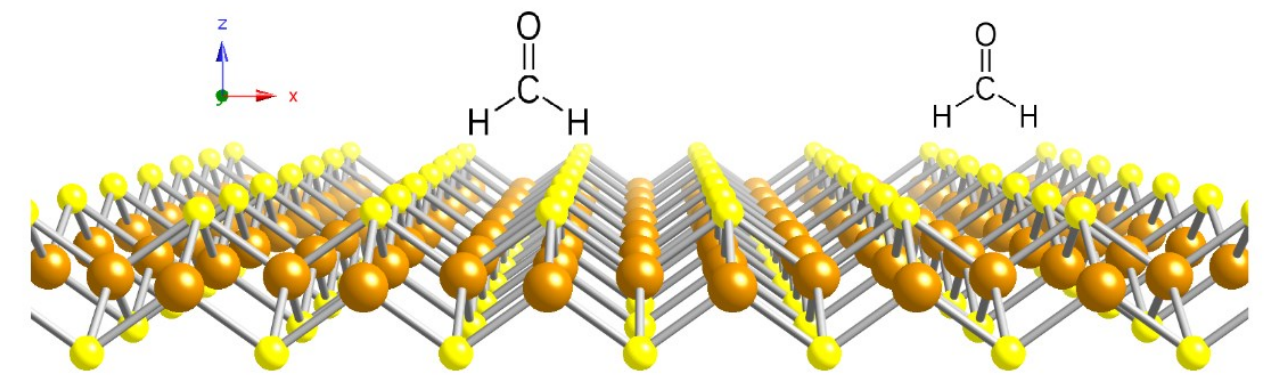

Figure 5.5: Ball and stick model of aldehyde selective oxidization on the mackinawite (001) surface. This selective oxidization suppresses pyrite formation while promoting greigite stability. Picture modified from Wang et al. (2015). 


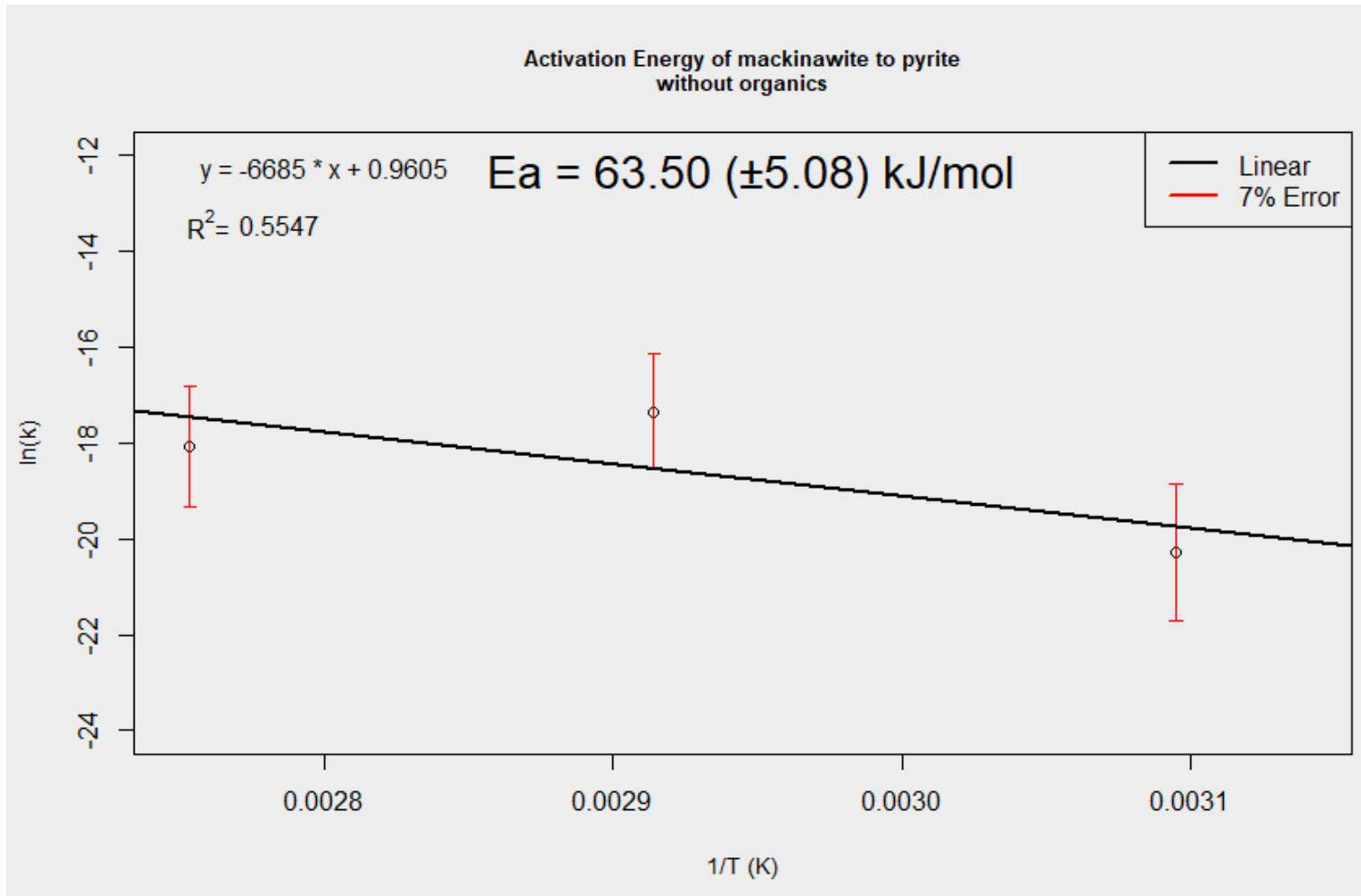

Figure 5.6: Plotting of the linear form of the Arrhenius equation provides a trendline to the experimental data; the trendline takes of the form of the standard slope equation $y=m x+b$. The slope of the line equals the negative activation energy related to the gas constant $(-\mathrm{Ea} / \mathrm{R})$, and the y-intercept equals $\ln (\mathrm{A})$. The Arrhenius calculations for these experiments were based on the ripening of mackinawite to pyrite. Experiments in this study produced rate constants of $1.47 \cdot 10^{-07}, 2.50 \cdot 10^{-06}$, and $2.62 \cdot 10^{-06}(\mathrm{mols} / \mathrm{sec})$ at 50,70 , and $90^{\circ} \mathrm{C}$ respectively. Application of the data calculated an activation energy of $63.50( \pm 5.08) \mathrm{kJ} / \mathrm{mol}$. Typically, solid state reactions produce an activation energy of 80-320 kJ/mol (Hunger and Benning, 2007). However, this activation energy is similar to the ripening of mackinawite to greigite calculated by Hunger and Benning (2007) of $67.5( \pm 10.6) \mathrm{kJ} / \mathrm{mol}$. 


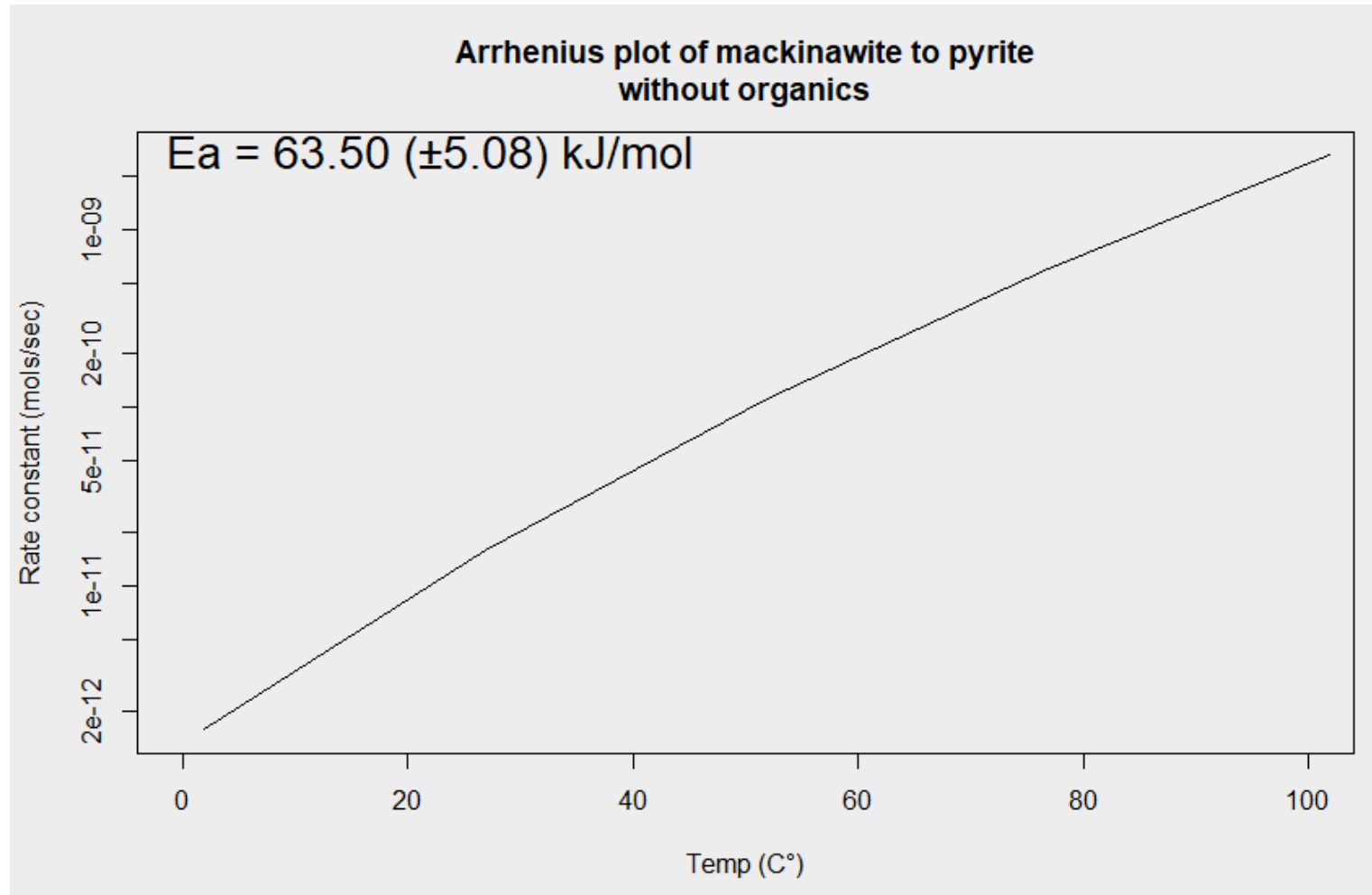

Figure 5.7: The Arrhenius calculations for these experiments were based on the ripening of mackinawite to pyrite. Experiments in this study produced rate constants of $1.47 \cdot 10^{-07}, 2.50 \cdot 10^{-}$ ${ }^{06}$, and $2.62 \cdot 10^{-06}(\mathrm{mols} / \mathrm{sec})$ at 50,70 , and $90^{\circ} \mathrm{C}$, respectively. Application of the data calculated an activation energy of $63.50( \pm 5.08) \mathrm{kJ} / \mathrm{mol}$. Typically, solid state reactions produce an activation energy of $80-320 \mathrm{~kJ} / \mathrm{mol}$ (Hunger and Benning, 2007). However, this activation energy is similar to the ripening of mackinawite to greigite calculated by Hunger and Benning (2007) of $67.5( \pm 10.6) \mathrm{kJ} / \mathrm{mol}$. Despite the low activation energy, the rate constant of the ripening of mackinawite to pyrite increases 22 -fold from $50-100^{\circ} \mathrm{C}$. 


\section{CHAPTER 6}

\section{CONCLUSIONS}

Experiments in this investigation did offer additional confirmation of Rickard's organic switch. Without formaldehyde, pyrite formation occurred as expected, and greigite was a metastable intermediate phase found as part of the iron sulfide ripening pathways. Since greigite forms in the aldehydes and the oceans are a large reservoir for aldehydes, a question arises why there is a lack of greigite in marine environments. Pyrite framboids are possibly pseudomorphs after greigite as a result of aldehyde selective oxidation.

In order to calibrate greigite weight percent in an iron sulfide deposit into an organic paleoenvironmental indicator, a large amount of background work must be completed. Firstly, aldehyde input into aqueous environments is variable and on-going. Aldehyde abundances through geological time would need calculating; similarly, to carbon-14 dating or dendrochronology. Individual major increases in aldehyde release must be accounted for as well. Events such as large forest fires, major volcanic eruptions, and mass extinction events would all create spikes in aldehyde relative abundance.

Due to the volatile nature of aldehydes, these calculations are currently not possible since there is no current way to determine paleo-aldehyde quantities in lacustrine and marine sediments, or in the rock record. Due to these complexities, the use of greigite as a paleoorganic indicator may not be viable for the foreseeable future. 


\section{APPENDIX}

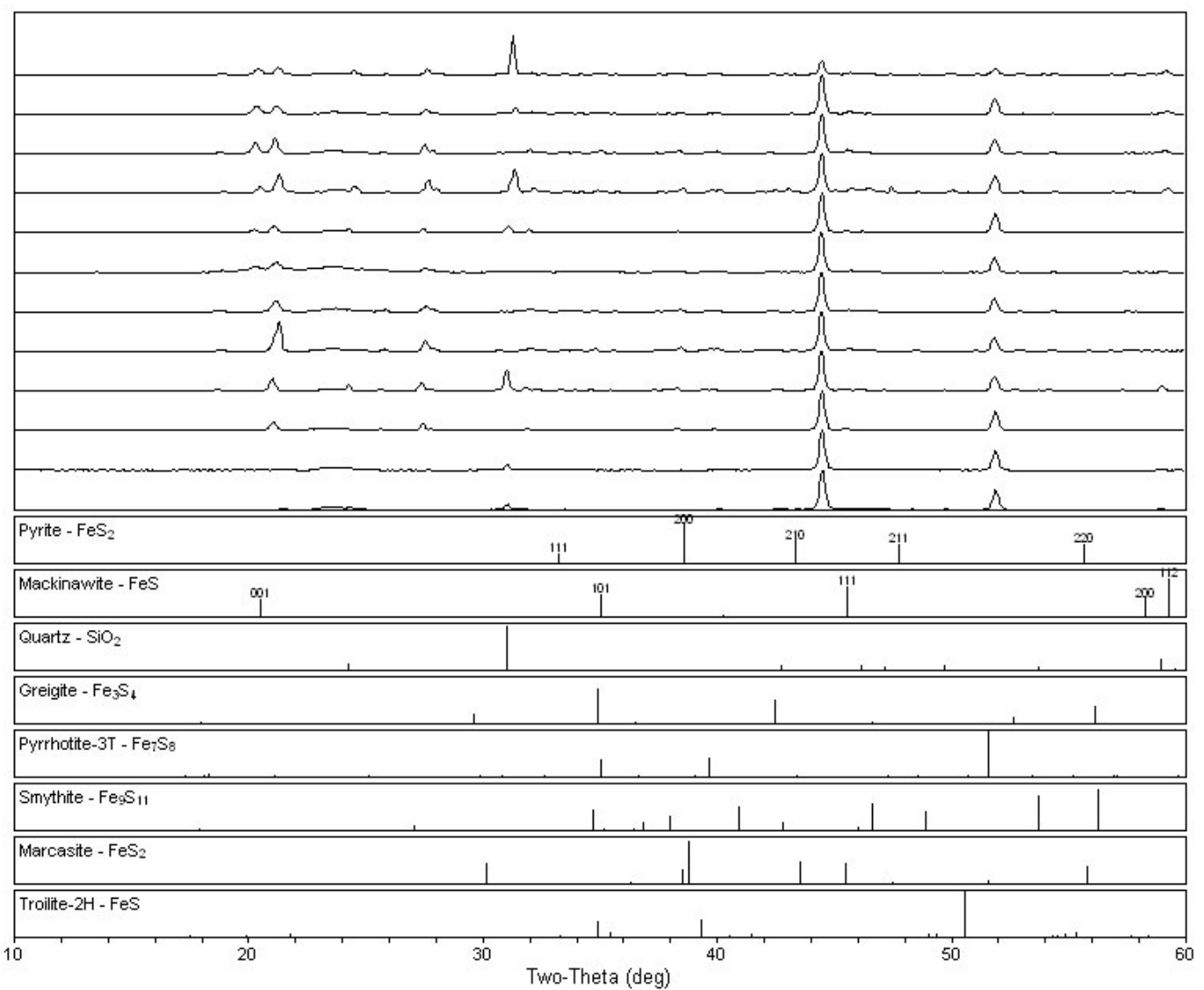

Stacked XRD pattern 07072018. Experiment run at $23^{\circ} \mathrm{C}$ with formalin. Time increasing up y-axis from 10-4110 minutes. 


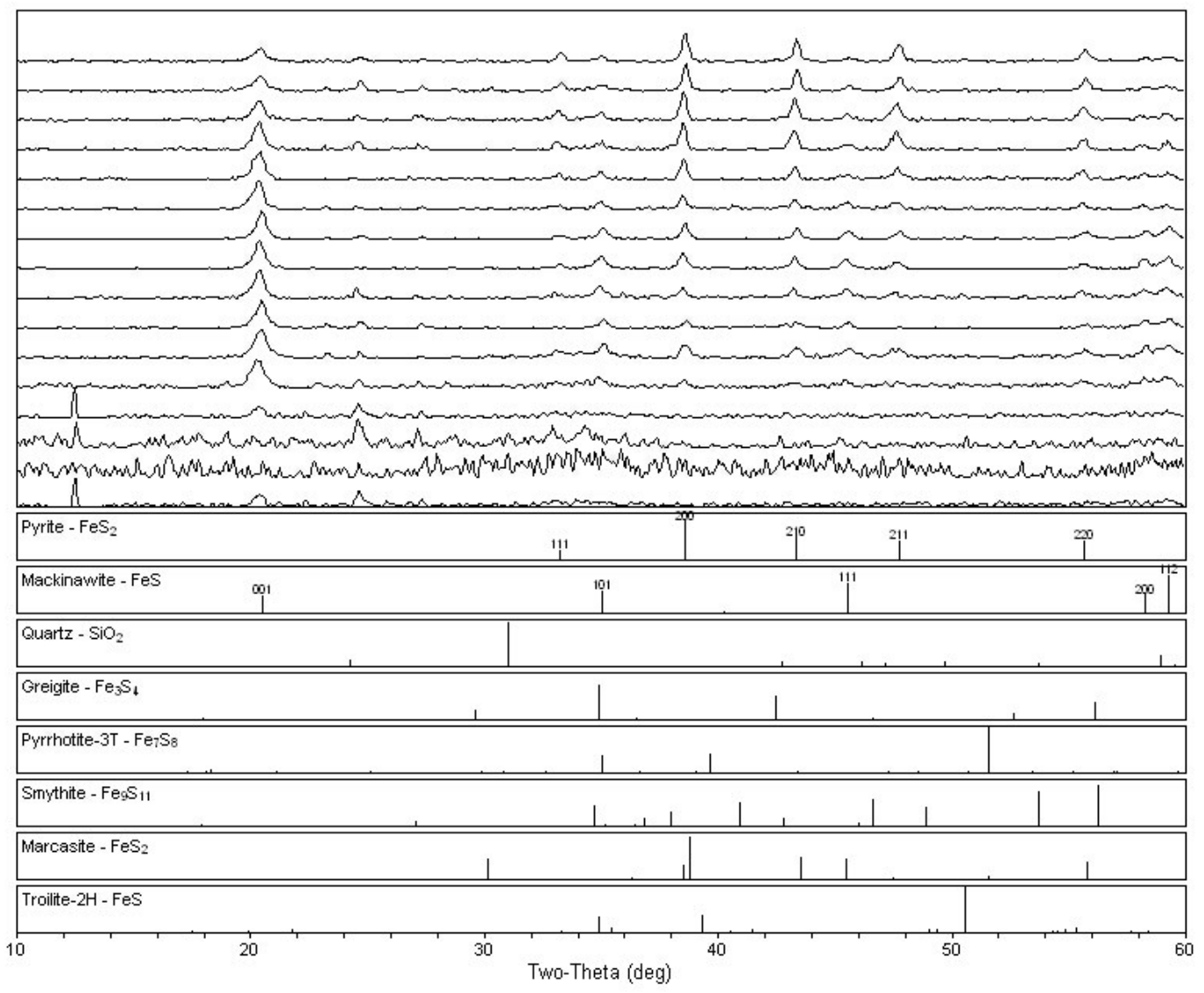

Stacked XRD pattern 09042018 . Experiment run at $50^{\circ} \mathrm{C}$ without formalin. Time increasing up $\mathrm{y}$-axis from 10-5520 minutes. 


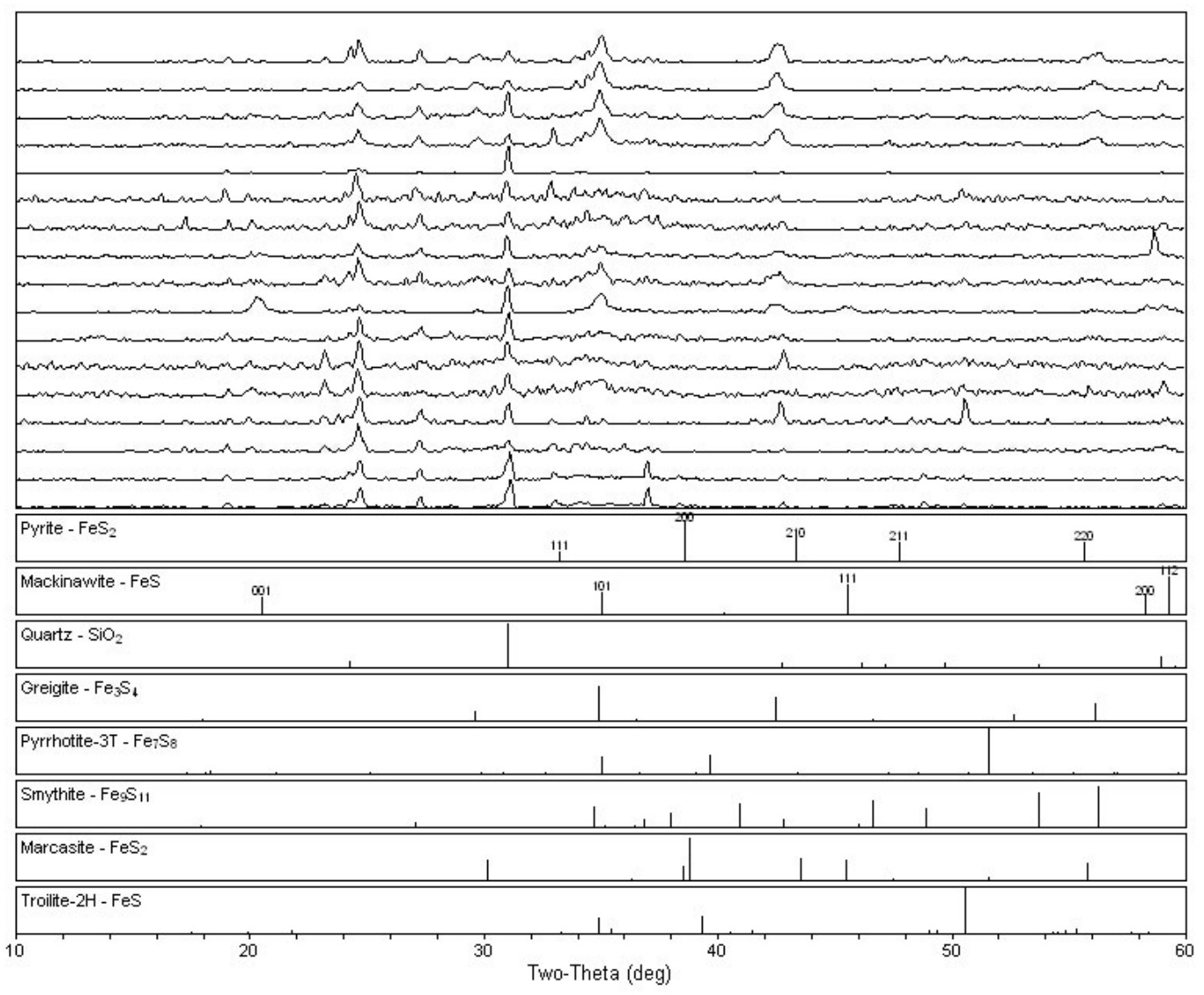

Stacked XRD pattern 09202018 . Experiment run at $70^{\circ} \mathrm{C}$ without formalin. Time increasing up y-axis from 10-1805 minutes. 


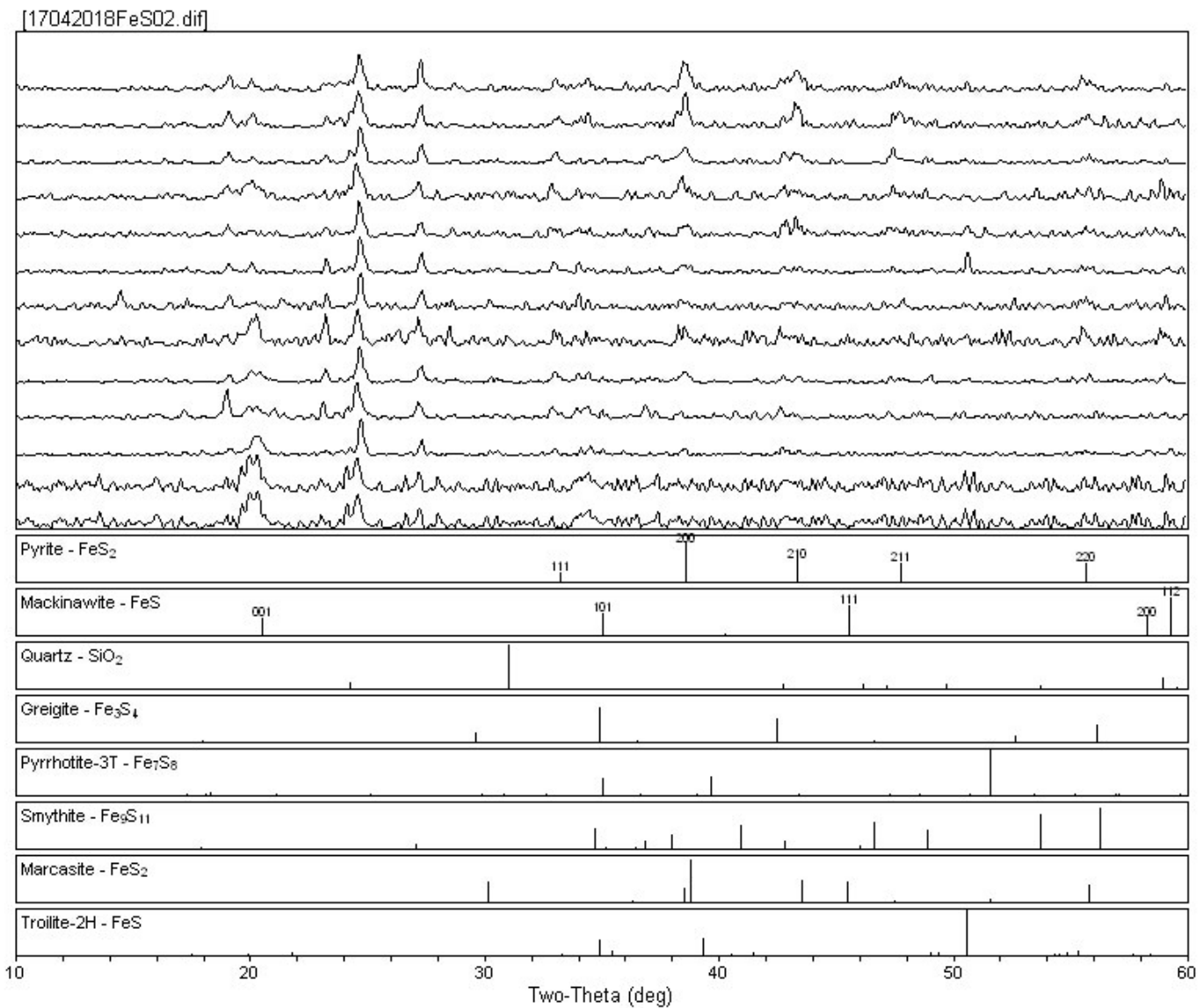

Stacked XRD pattern 17042018 . Experiment run at $23^{\circ} \mathrm{C}$ without formalin. Time increasing up y-axis from 10-1902 minutes. 


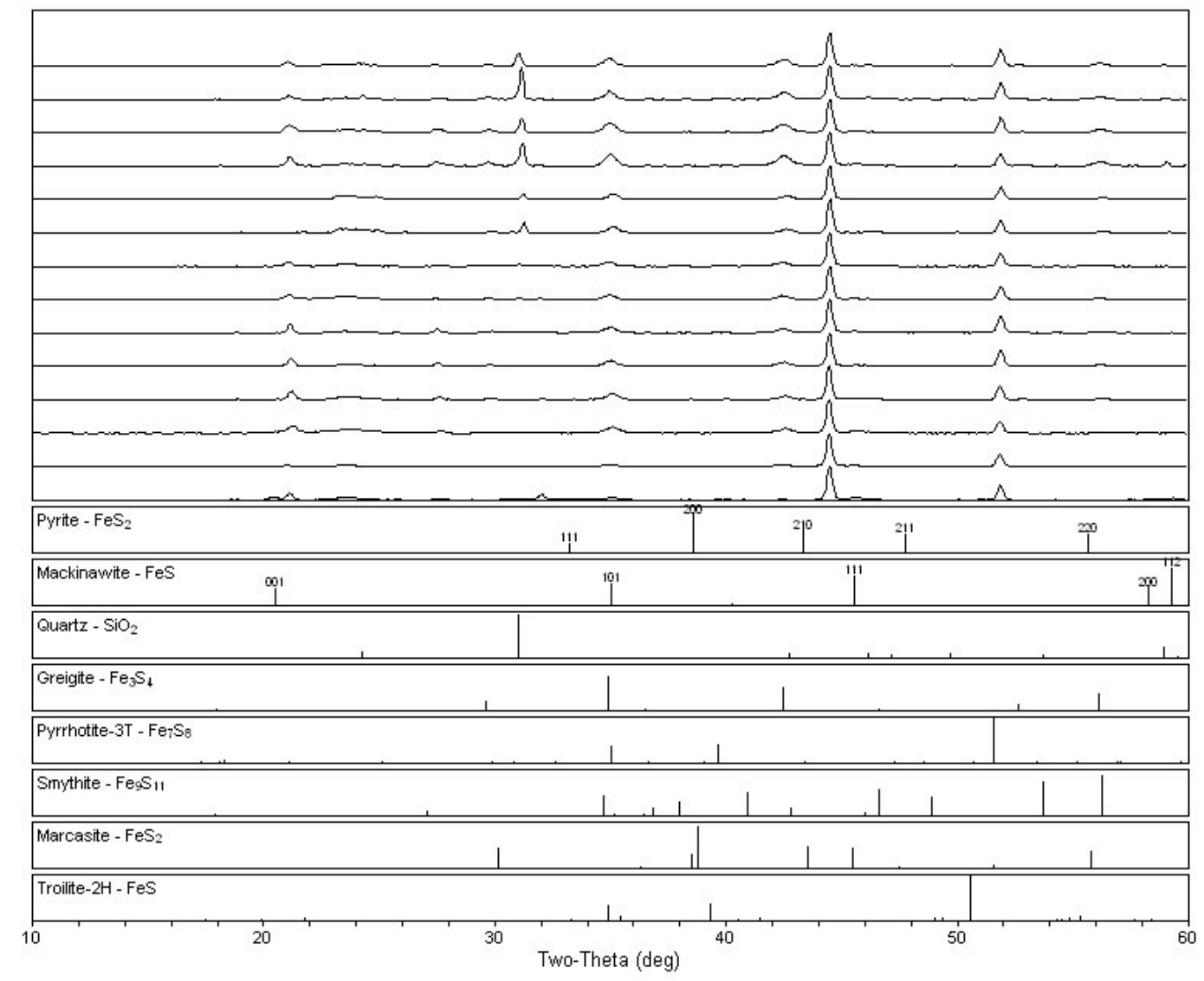

Stacked XRD pattern 07072018 . Experiment run at $70^{\circ} \mathrm{C}$ without formalin. Time increasing up $\mathrm{y}$-axis from 10-1800 minutes. 


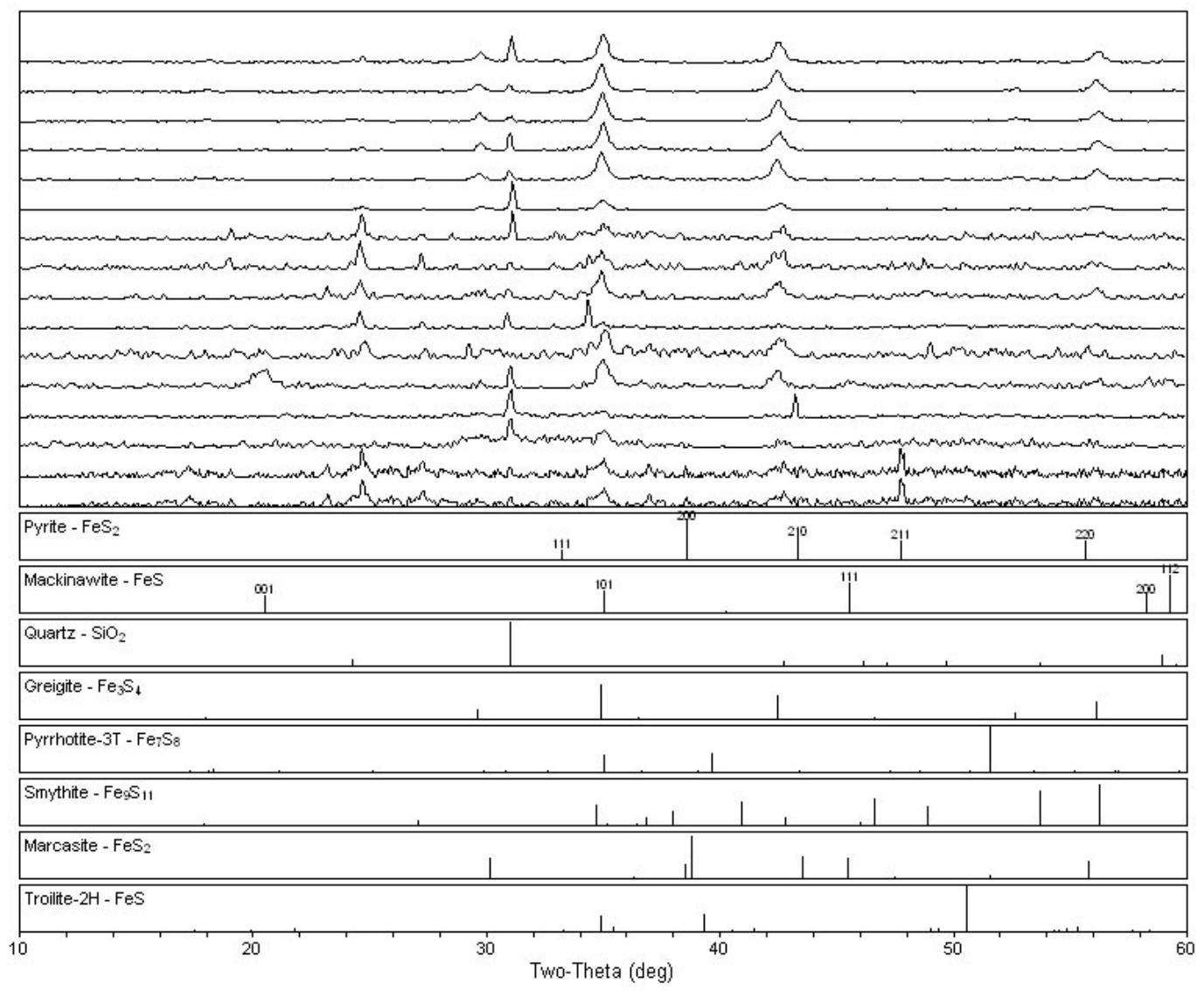

Stacked XRD pattern 09182018. Experiment run at $90^{\circ} \mathrm{C}$ without formalin. Time increasing up y-axis from 10-520 minutes. 


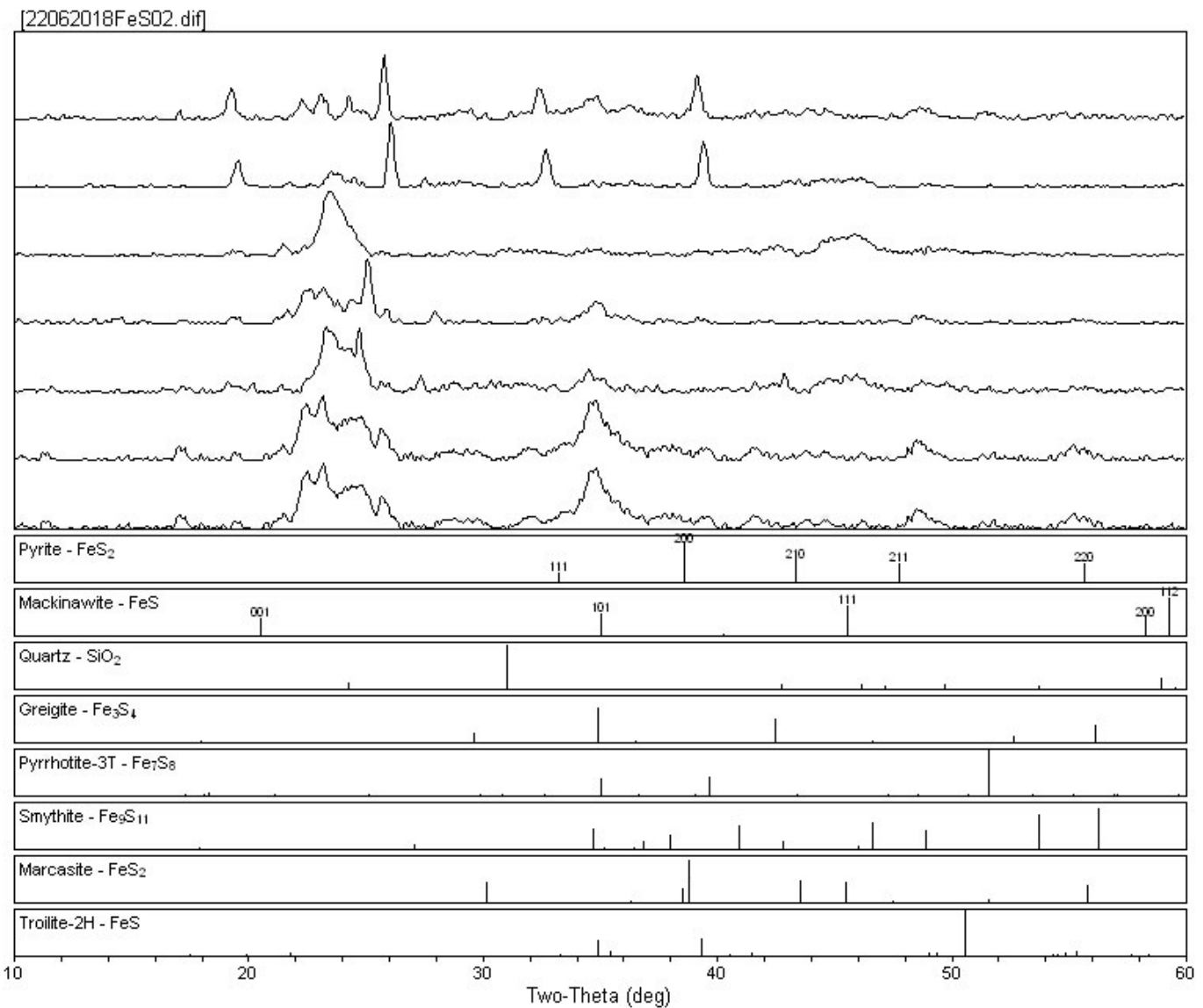

Stacked XRD pattern 22062018. Experiment run at $23^{\circ} \mathrm{C}$ with formalin. Time increasing up y-axis from 10- minutes. Run failed before completion 


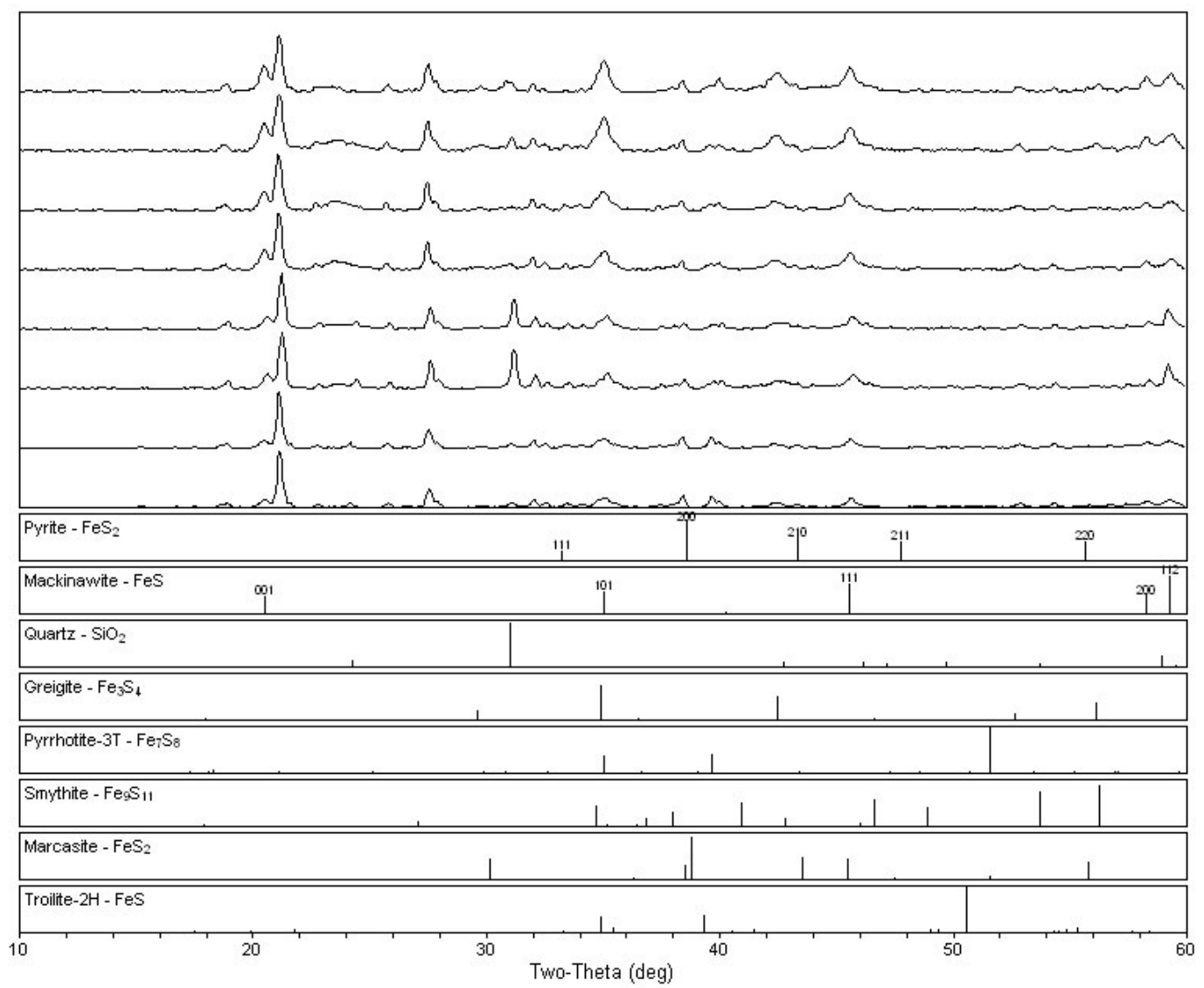

Stacked XRD pattern 24072018 . Experiment run at $70^{\circ} \mathrm{C}$ with formalin. Time increasing up y-axis from 10-473 minutes. 


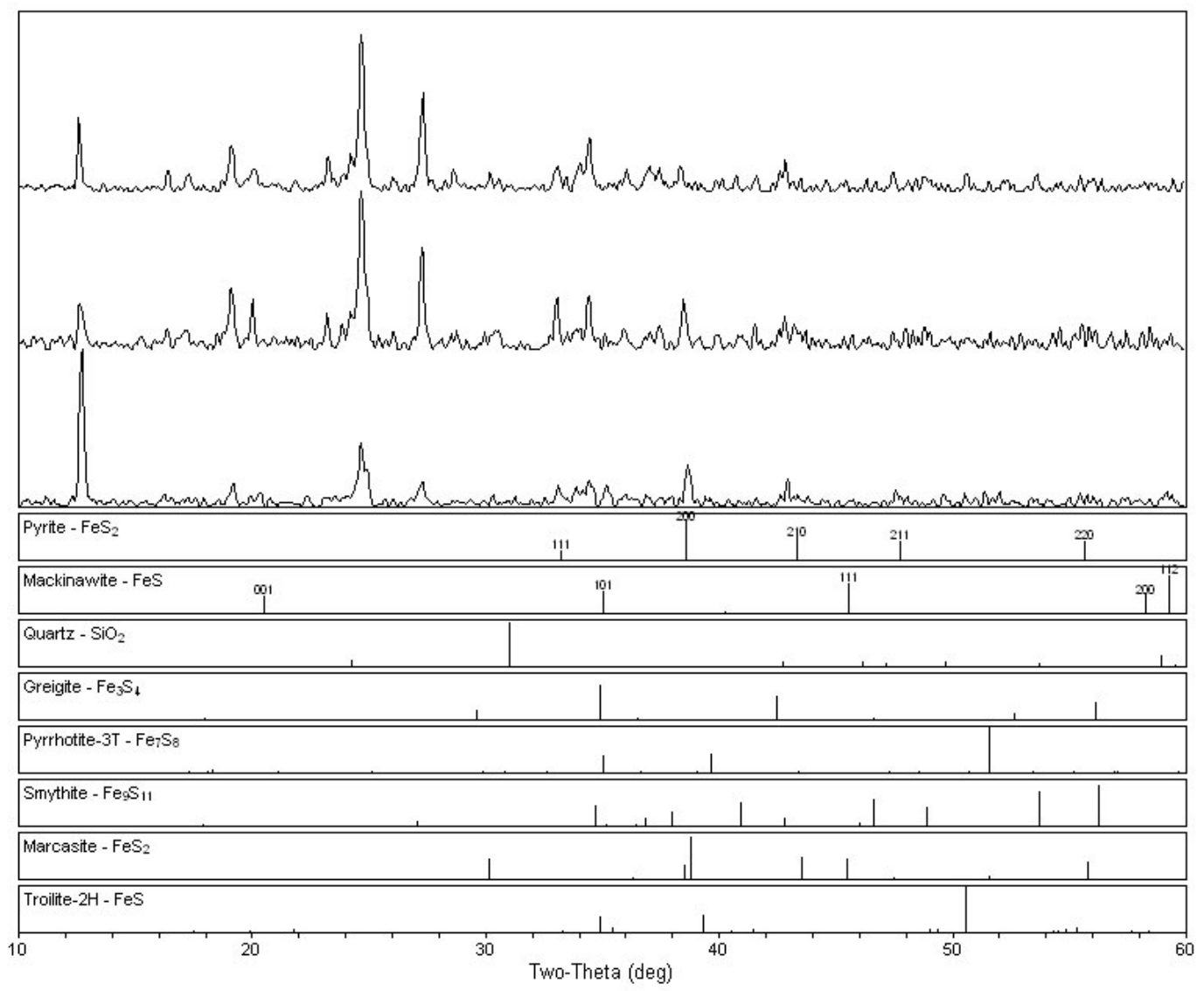

Stacked XRD pattern 25042018. Experiment run at $23^{\circ} \mathrm{C}$ with formalin. Time increasing up y-axis from 10-4110 minutes. 


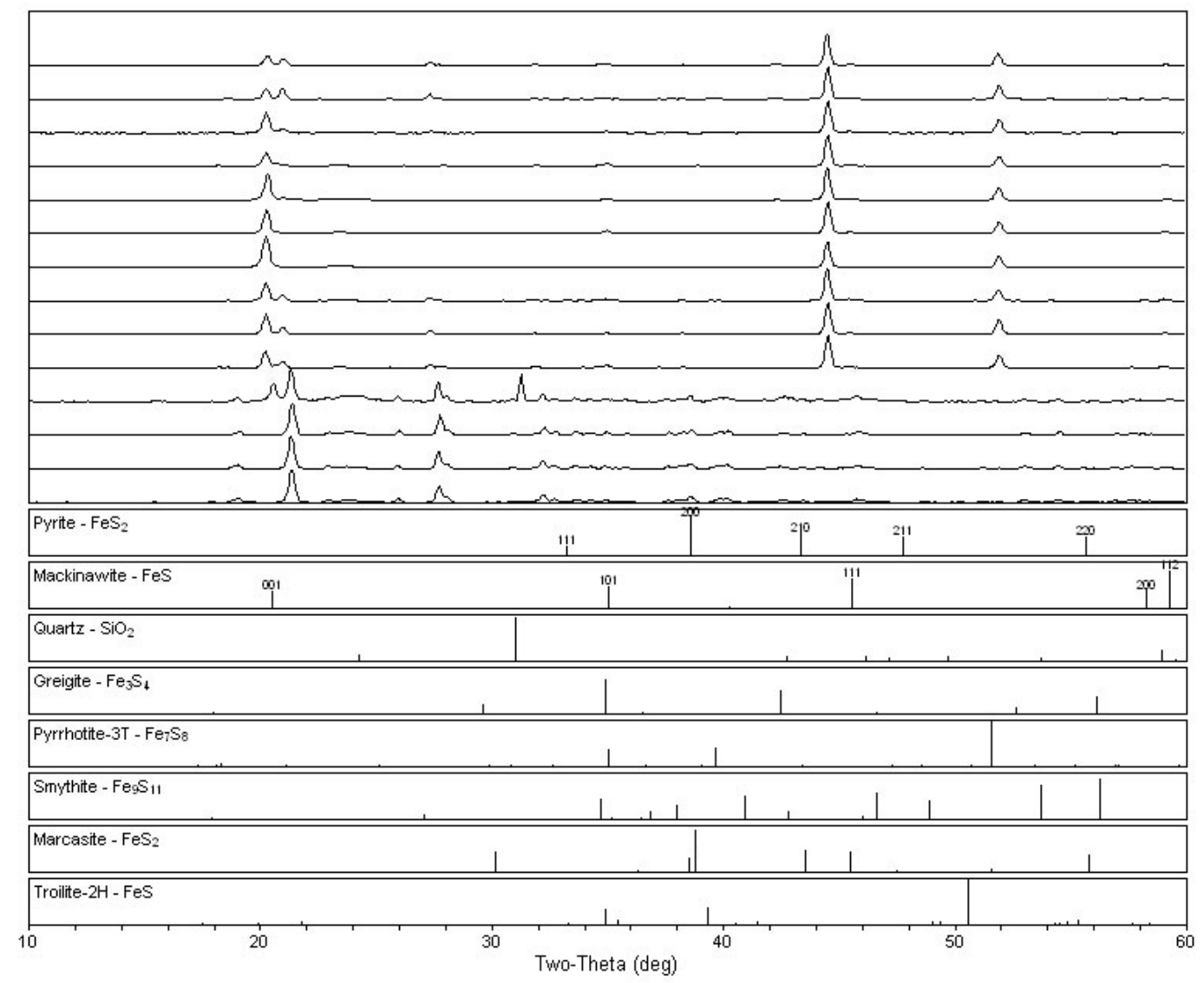

Stacked XRD pattern 30062018 . Experiment run at $50^{\circ} \mathrm{C}$ with formalin. Time increasing up y-axis from 10-5569 minutes. 


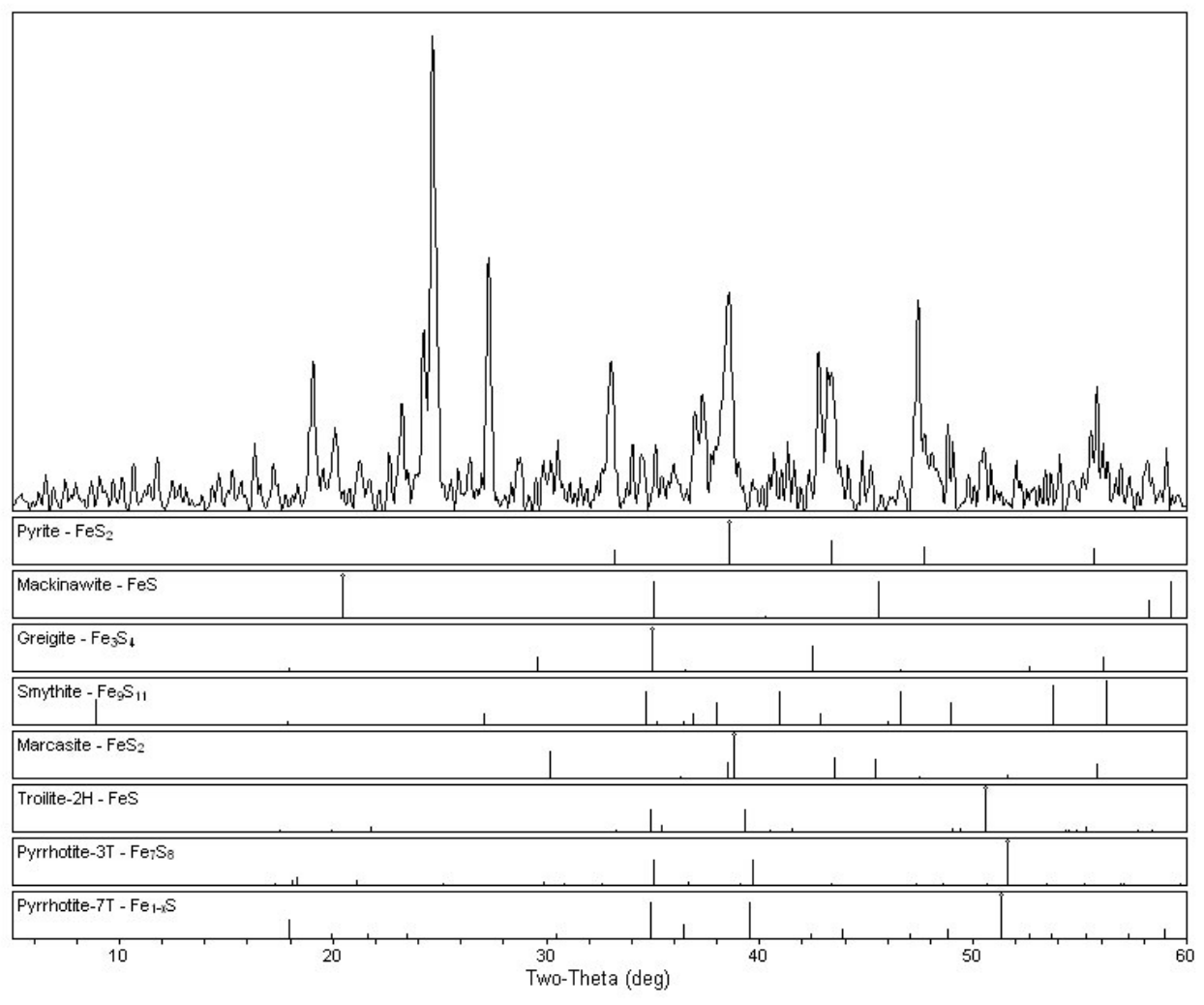

XRD pattern with background deleted of Run ID 17042018 - 2880-minute extraction. $23^{\circ} \mathrm{C}$ without organics. 


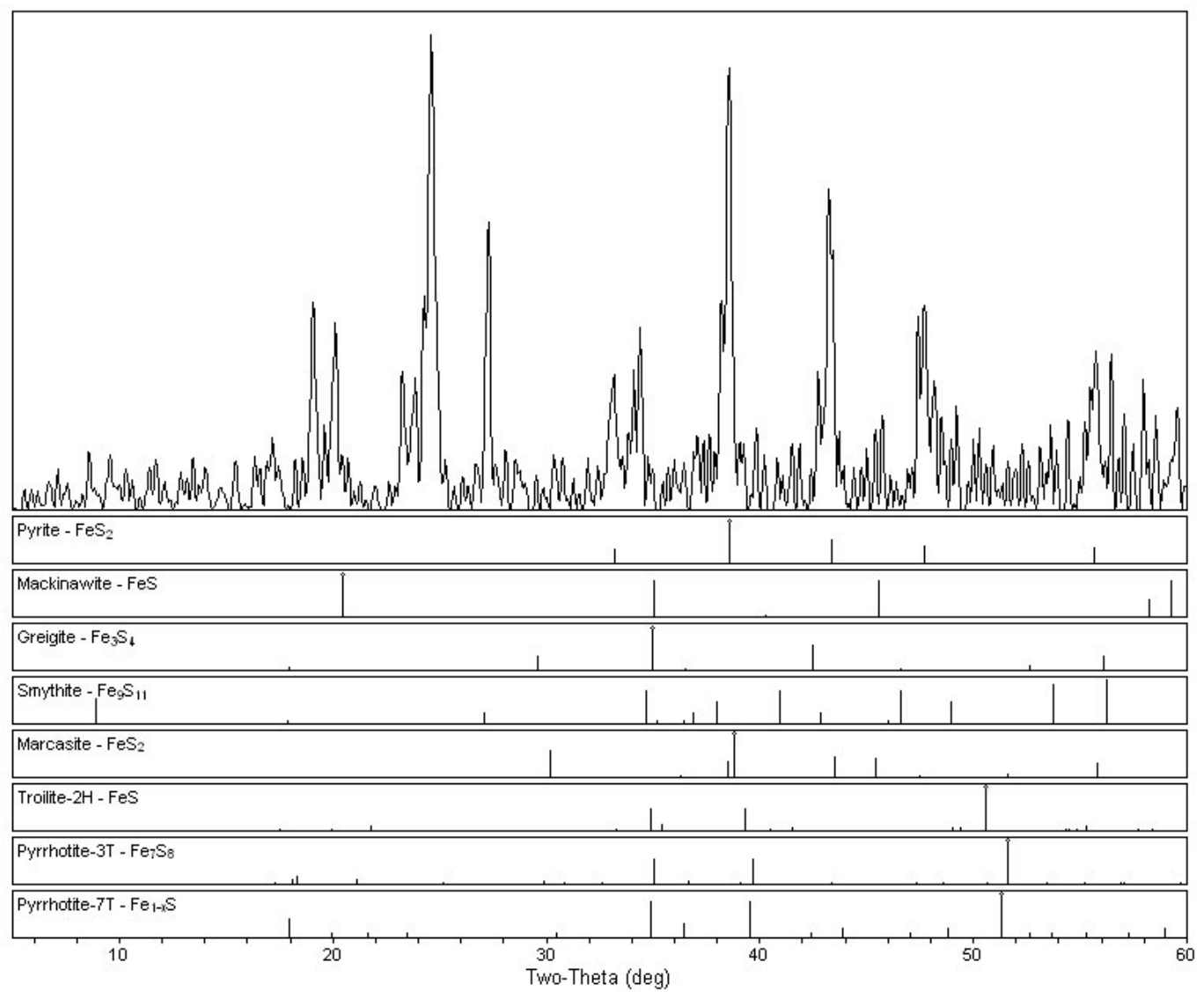

XRD pattern with background deleted of Run ID 17042018 - 3360-minute extraction. $23^{\circ} \mathrm{C}$ without organics. 


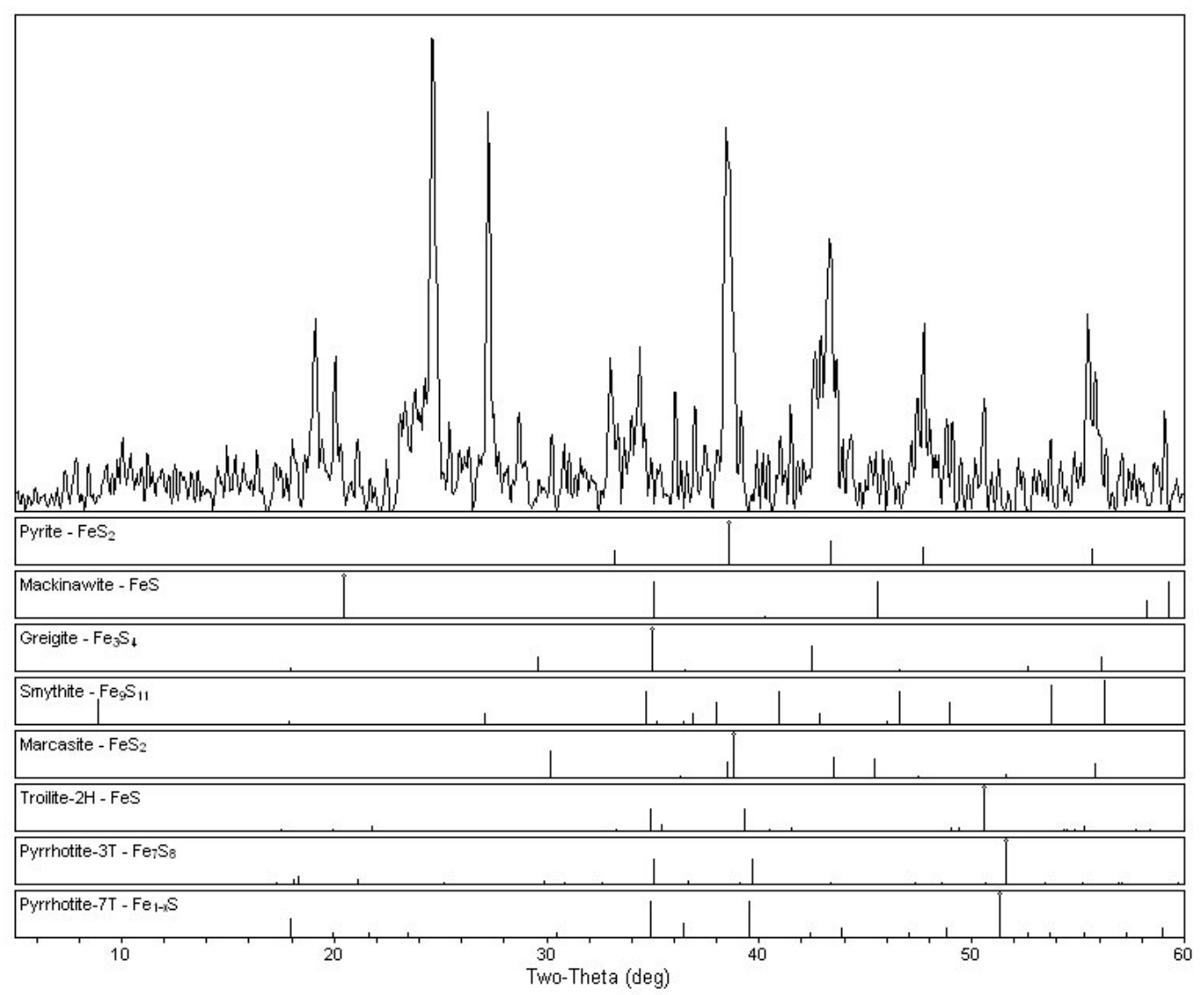

XRD pattern with background deleted of Run ID 17042018 - 4080-minute extraction. $23^{\circ} \mathrm{C}$ without organics. Image produced in Jade by Joseph A. Nolan. 


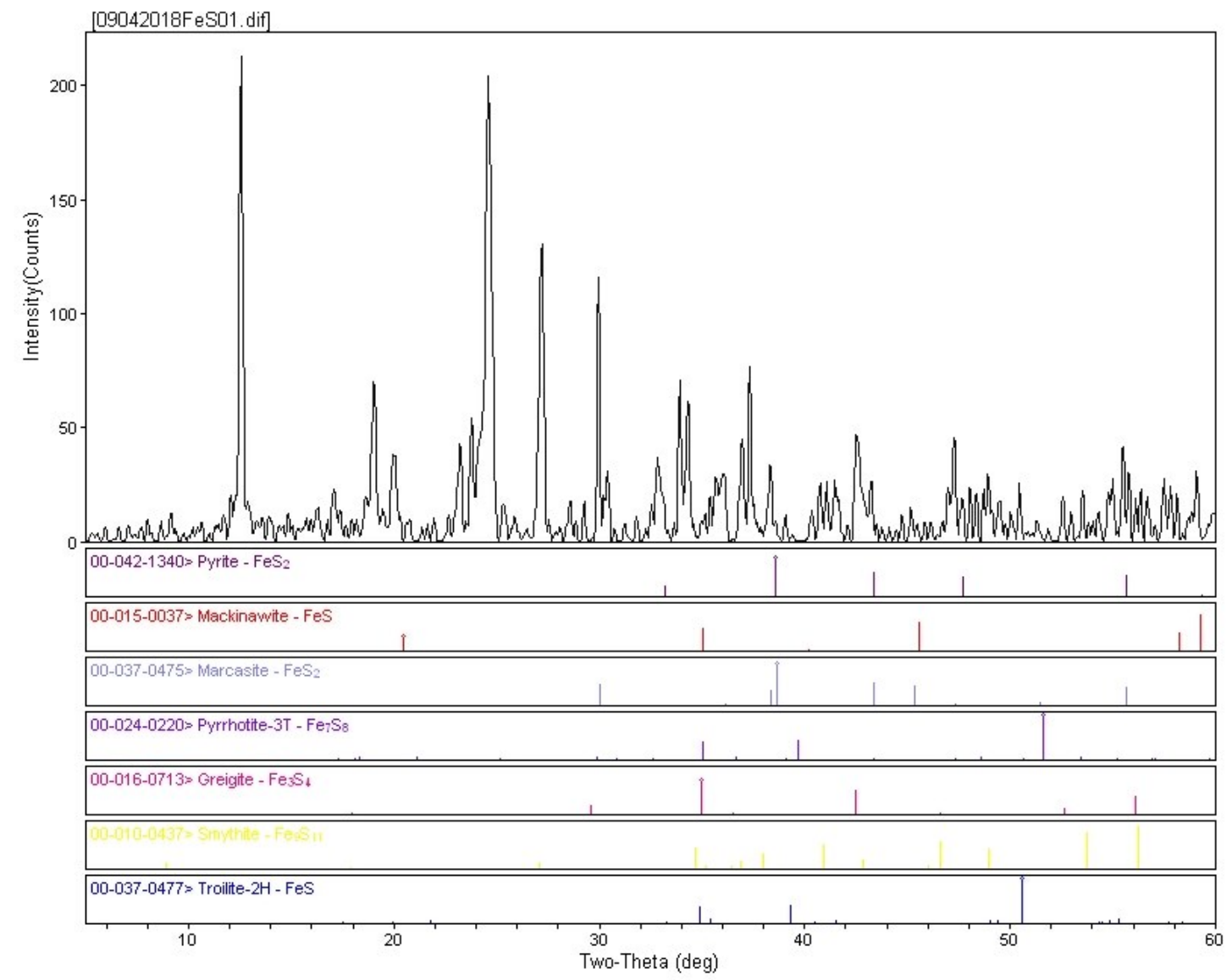

XRD pattern with background deleted of Run ID 09042018 - 10-minute extraction. $50^{\circ} \mathrm{C}$ without organics. 


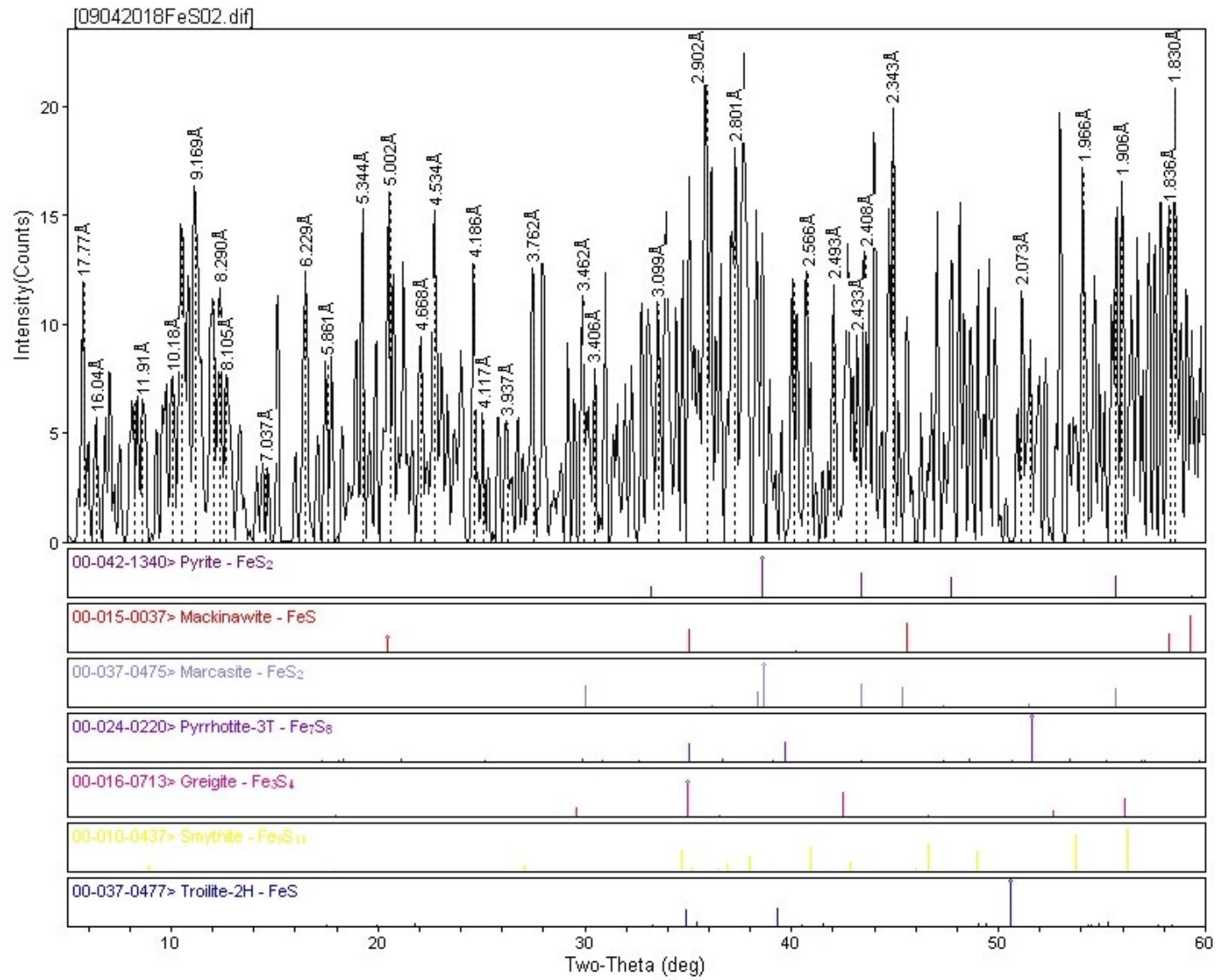

XRD pattern with background deleted of Run ID 09042018 - 60-minute extraction. $50^{\circ} \mathrm{C}$ without organics. Image produced in Jade by Joseph A. Nolan. 


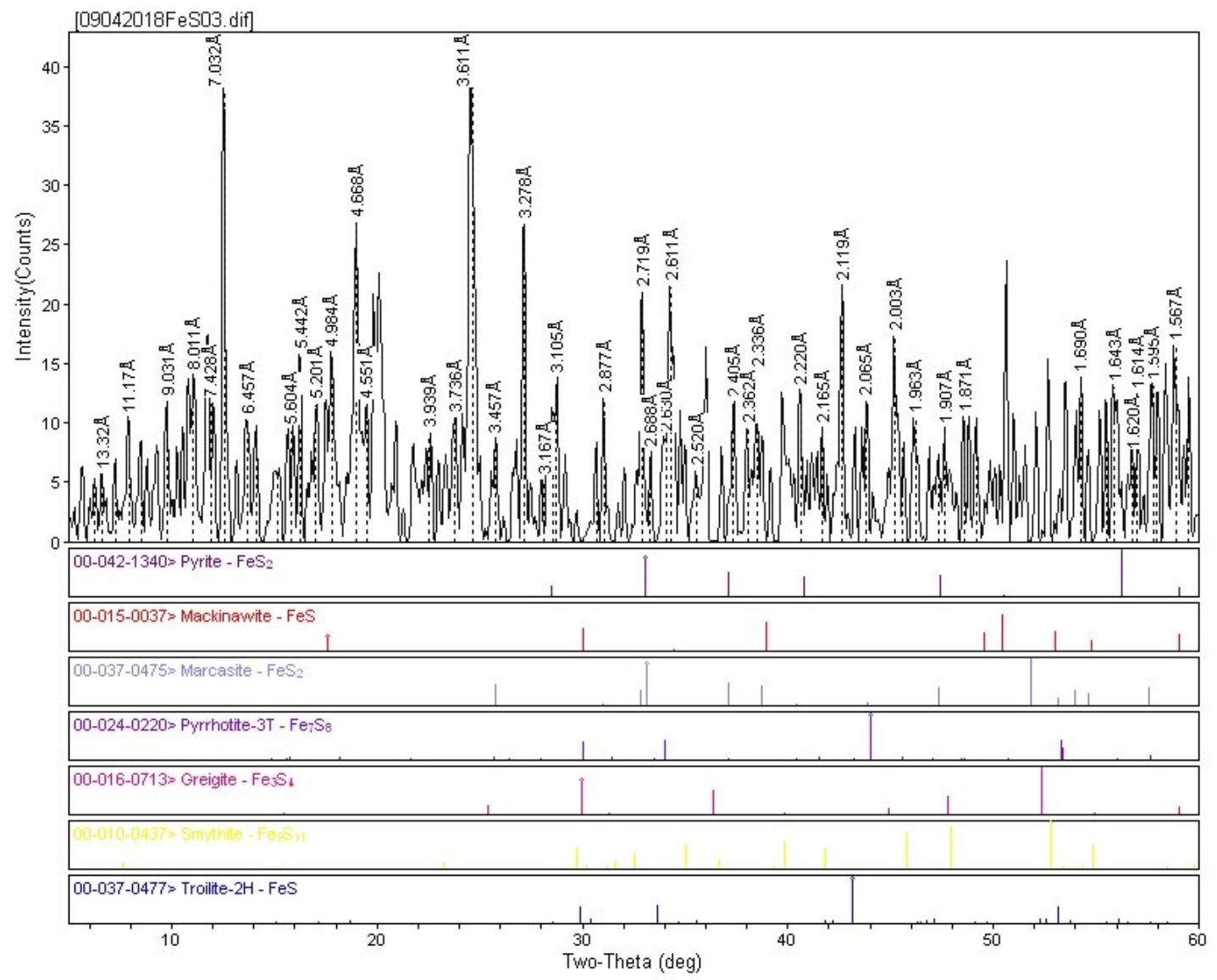

XRD pattern with background deleted of Run ID 09042018 - 90-minute extraction. $50^{\circ} \mathrm{C}$ without organics. 


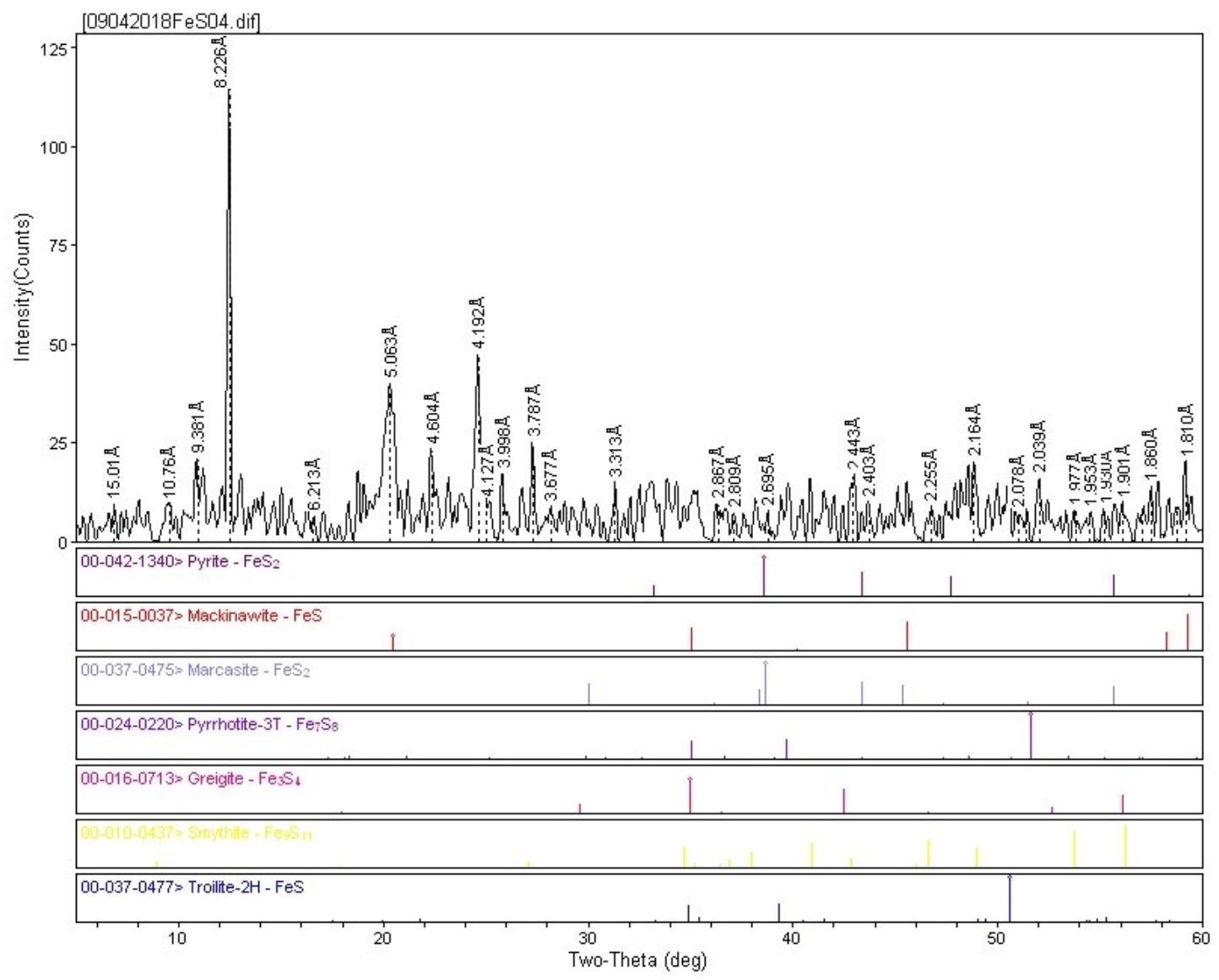

XRD pattern with background deleted of Run ID 09042018 - 120 -minute extraction. $50^{\circ} \mathrm{C}$ without organics. 


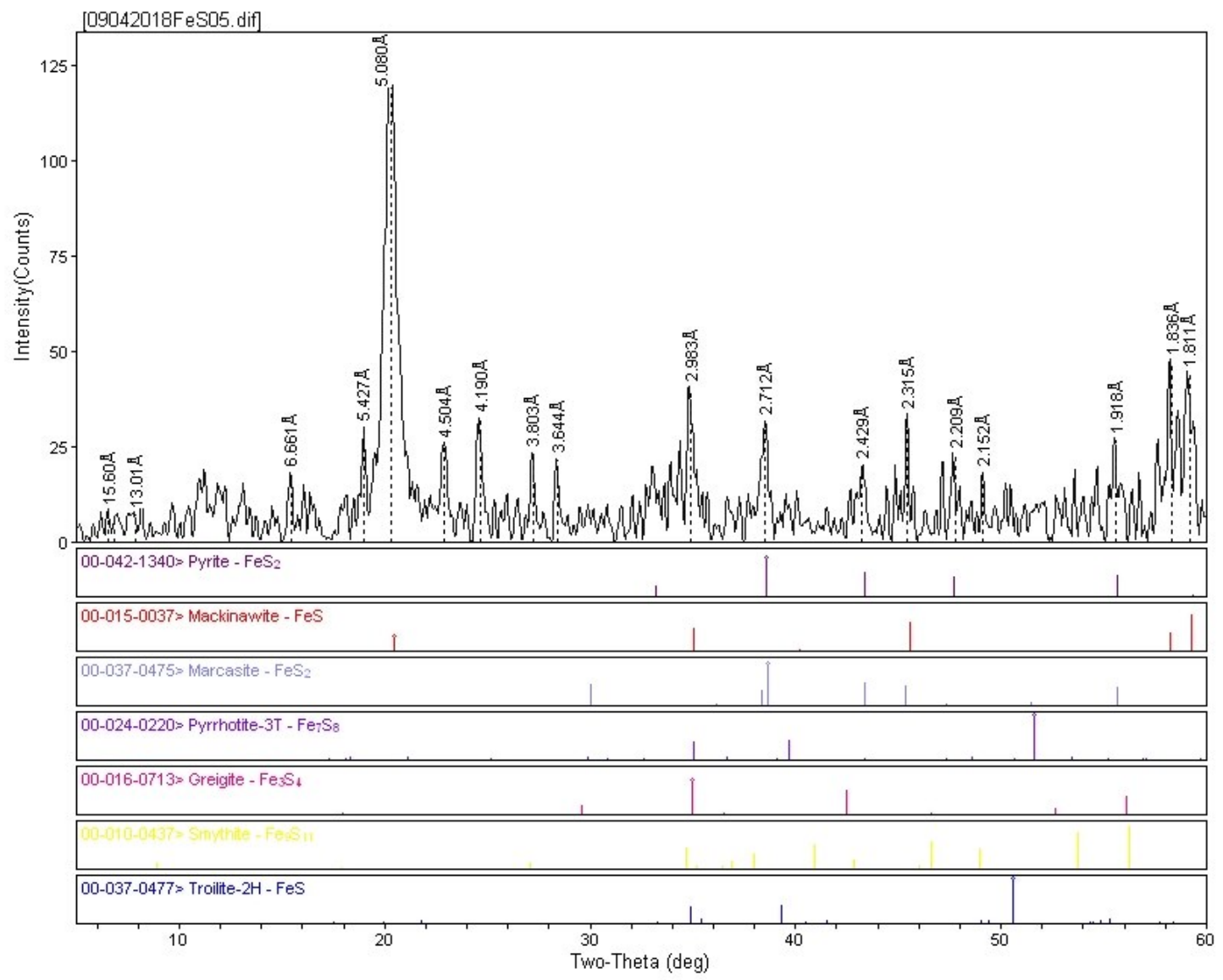

XRD pattern with background deleted of Run ID 09042018 - 240-minute extraction. $50^{\circ} \mathrm{C}$ without organics. 


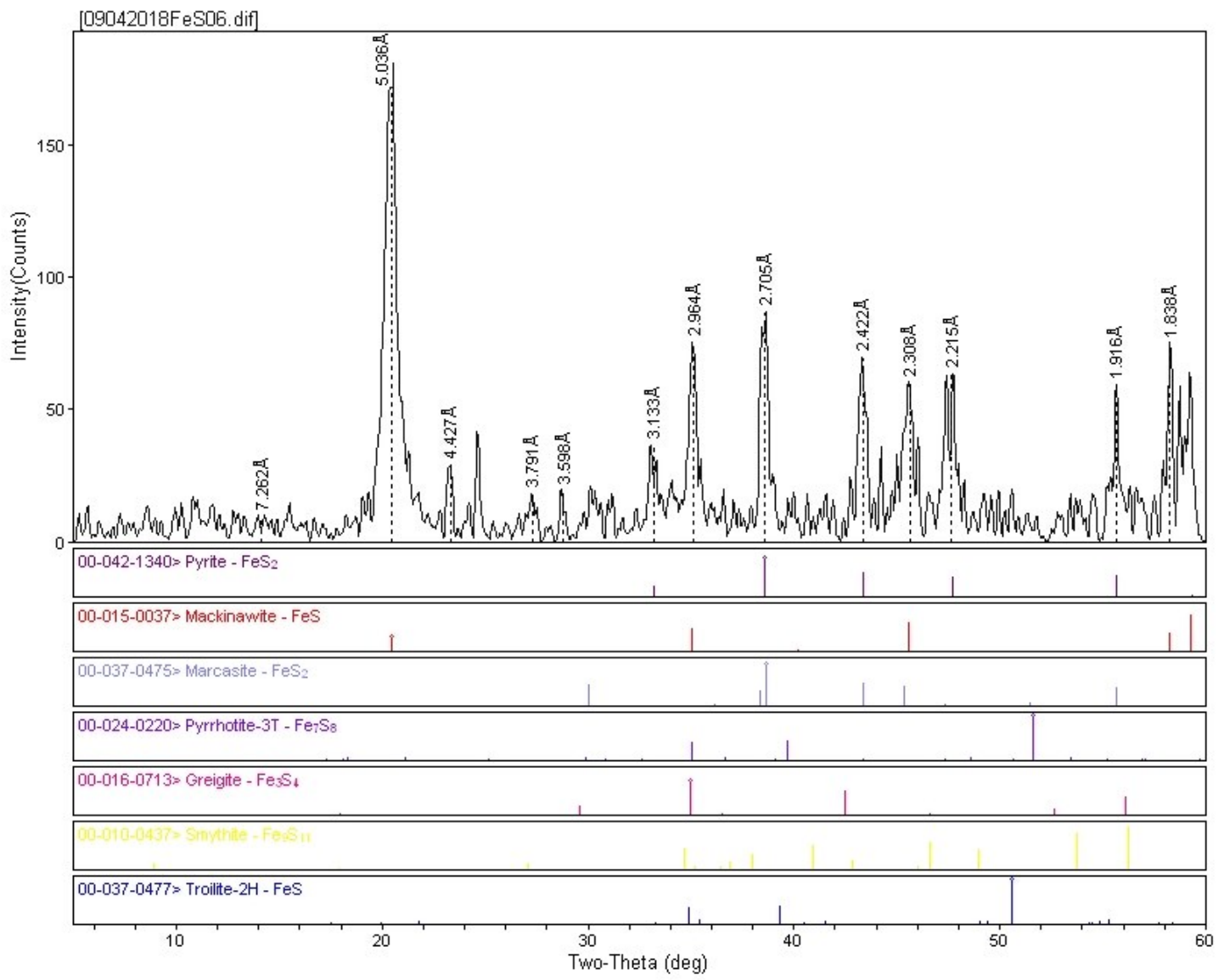

XRD pattern with background deleted of Run ID 09042018 - 480-minute extraction. $50^{\circ} \mathrm{C}$ without organics. 


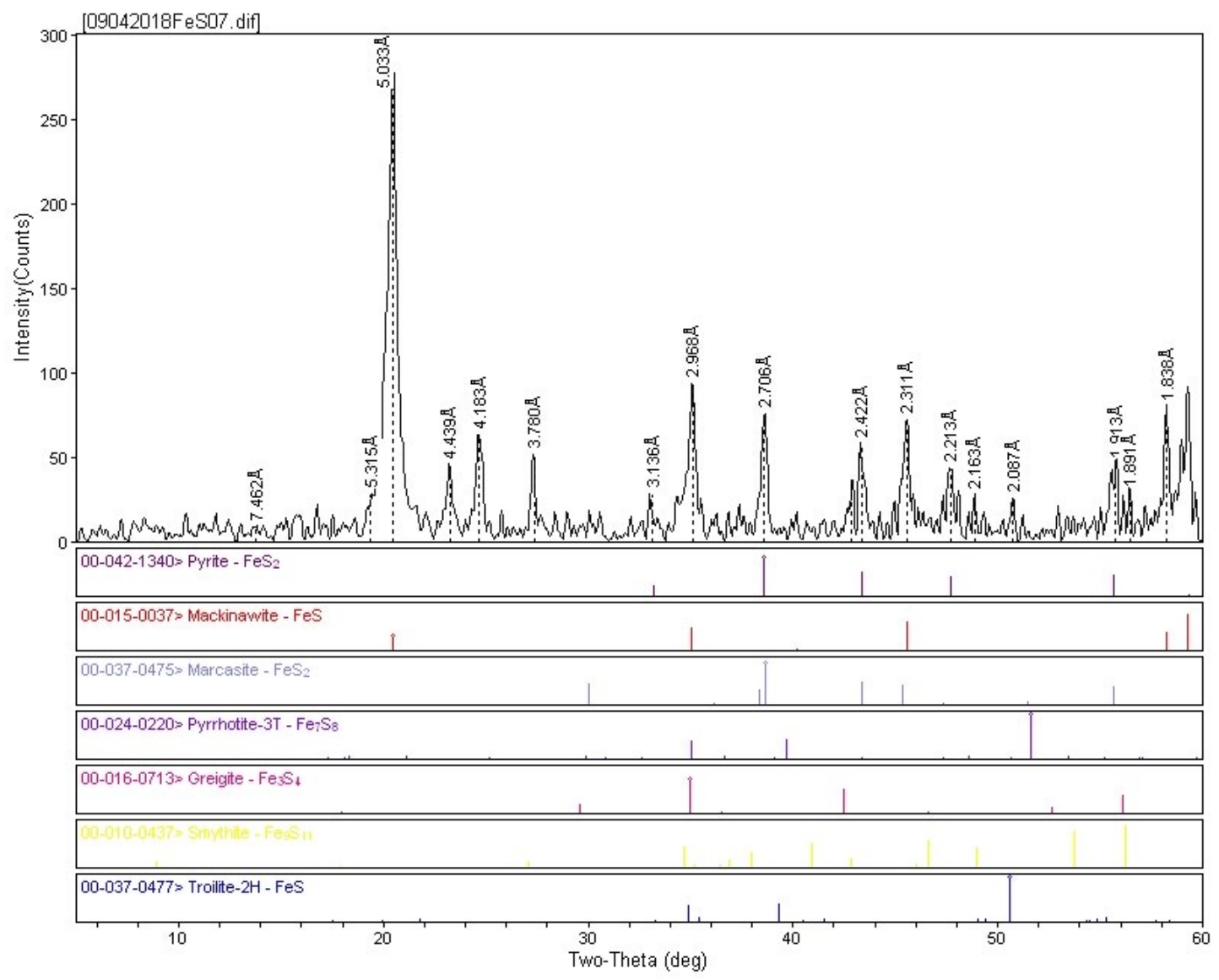

XRD pattern with background deleted of Run ID 09042018 - 960-minute extraction. $50^{\circ} \mathrm{C}$ without organics. 


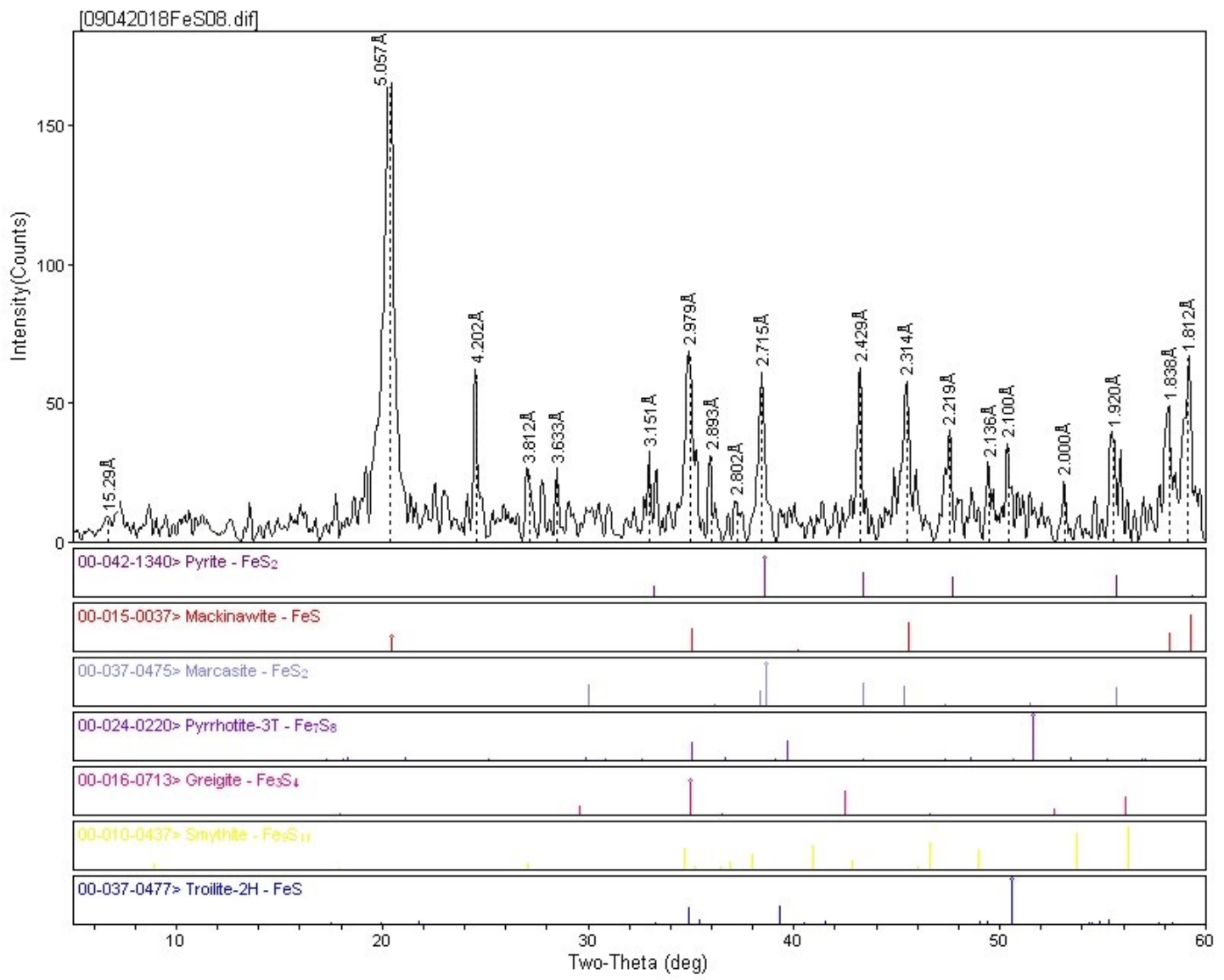

XRD pattern with background deleted of Run ID 09042018 - 1440 -minute extraction. $50^{\circ} \mathrm{C}$ without organics. 


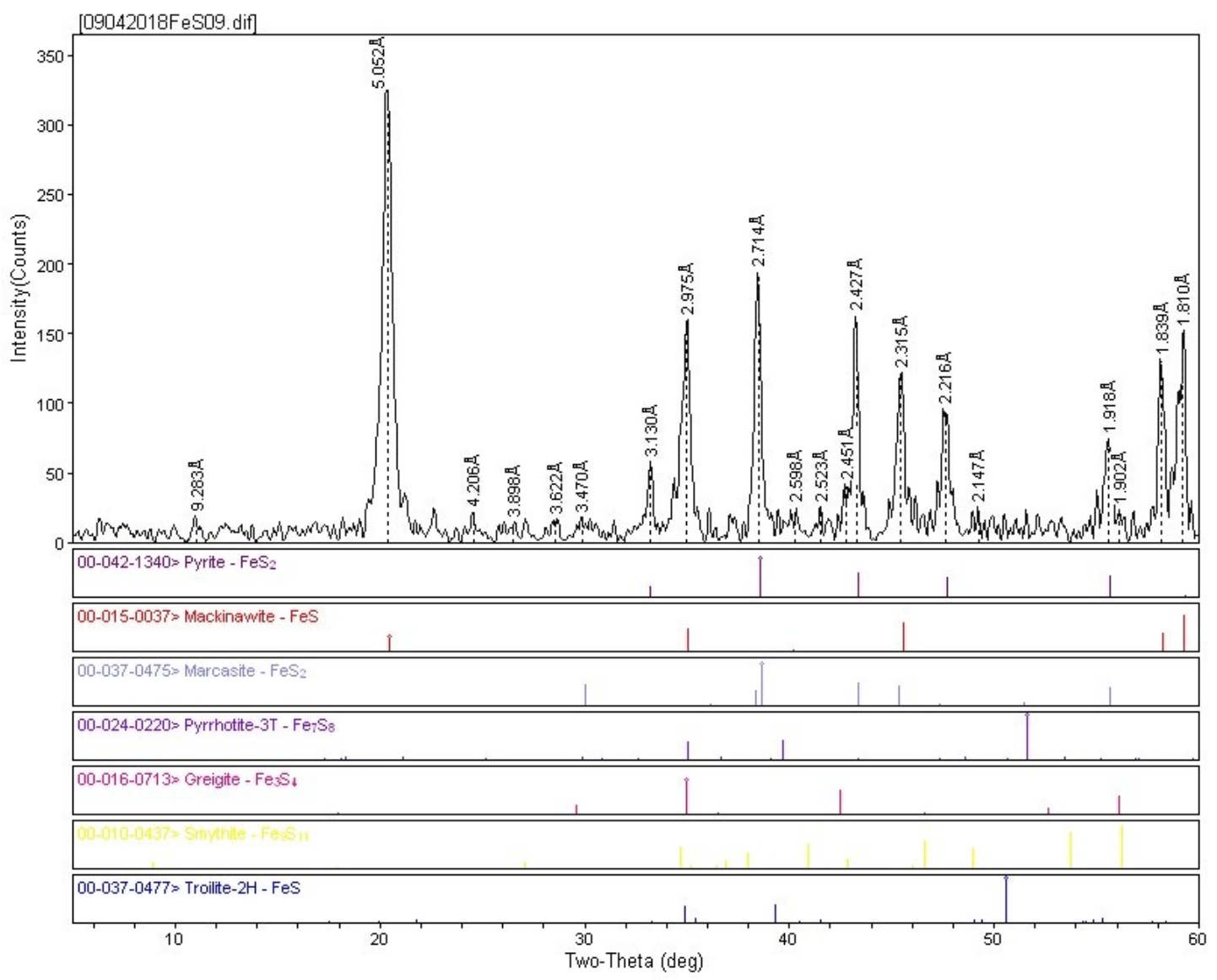

XRD pattern with background deleted of Run ID 09042018 - 1920-minute extraction. $50^{\circ} \mathrm{C}$ without organics. 


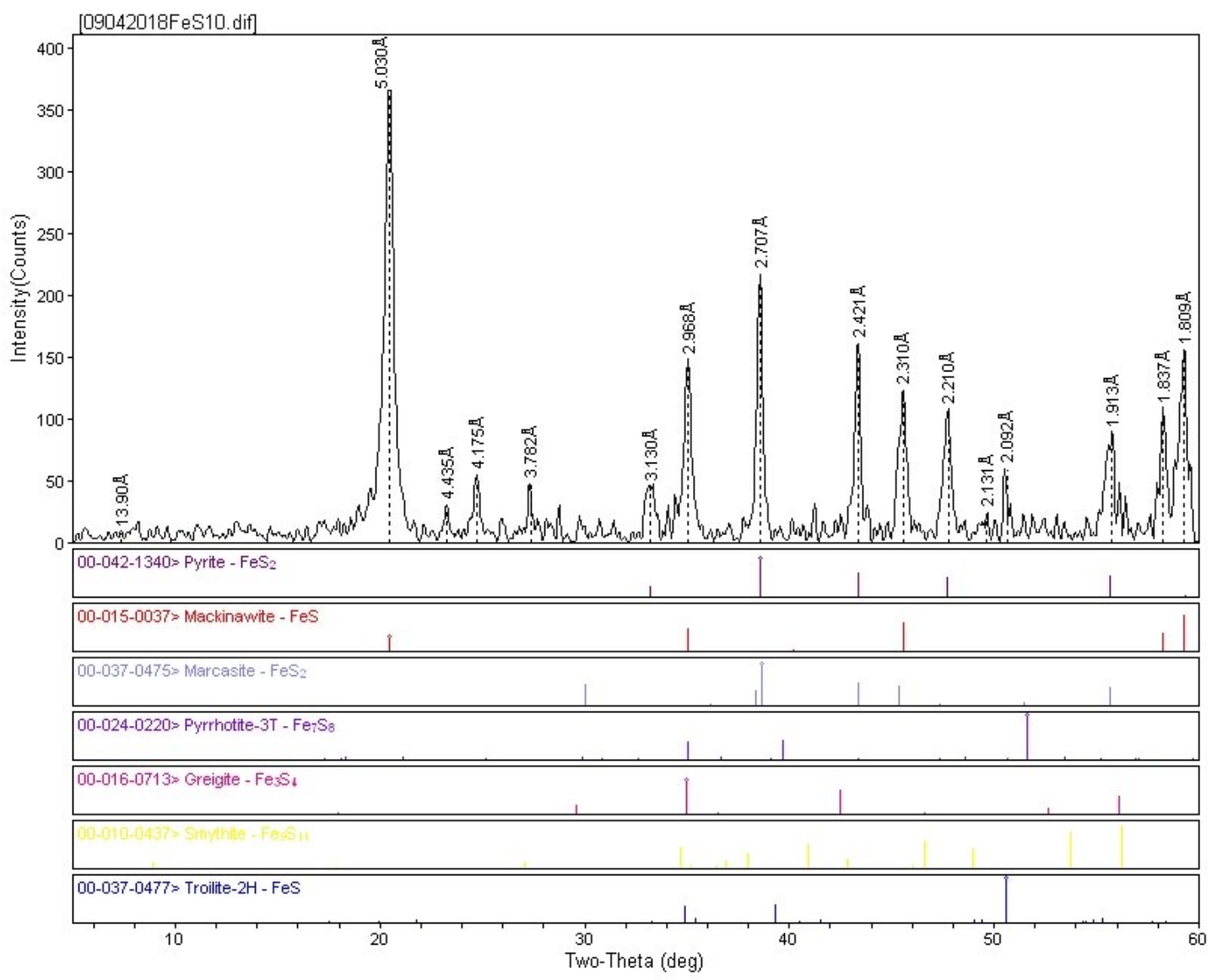

XRD pattern with background deleted of Run ID 09042018 - 2400-minute extraction. $50^{\circ} \mathrm{C}$ without organics. 


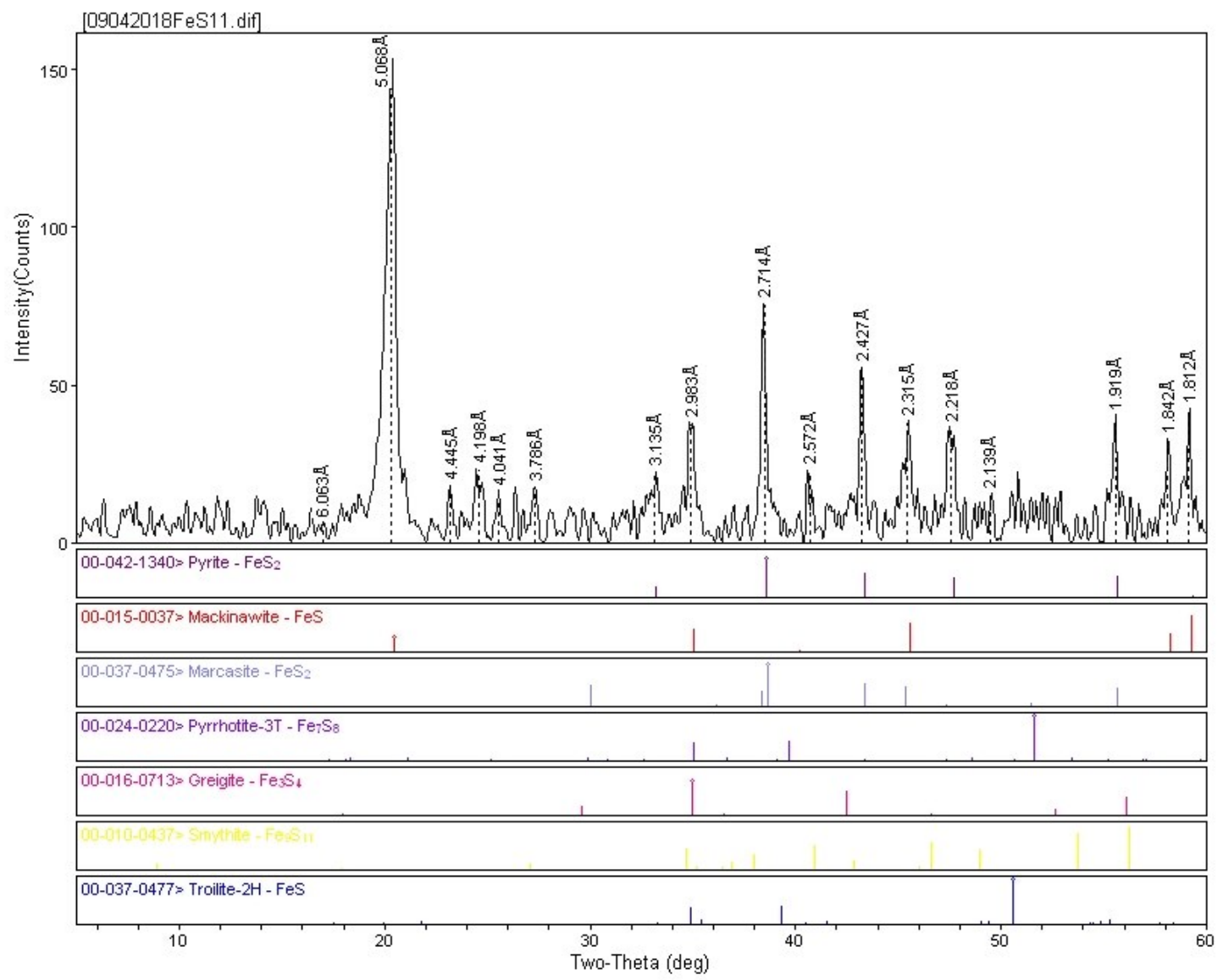

XRD pattern with background deleted of Run ID 09042018 - 2880-minute extraction. $50^{\circ} \mathrm{C}$ without organics. 


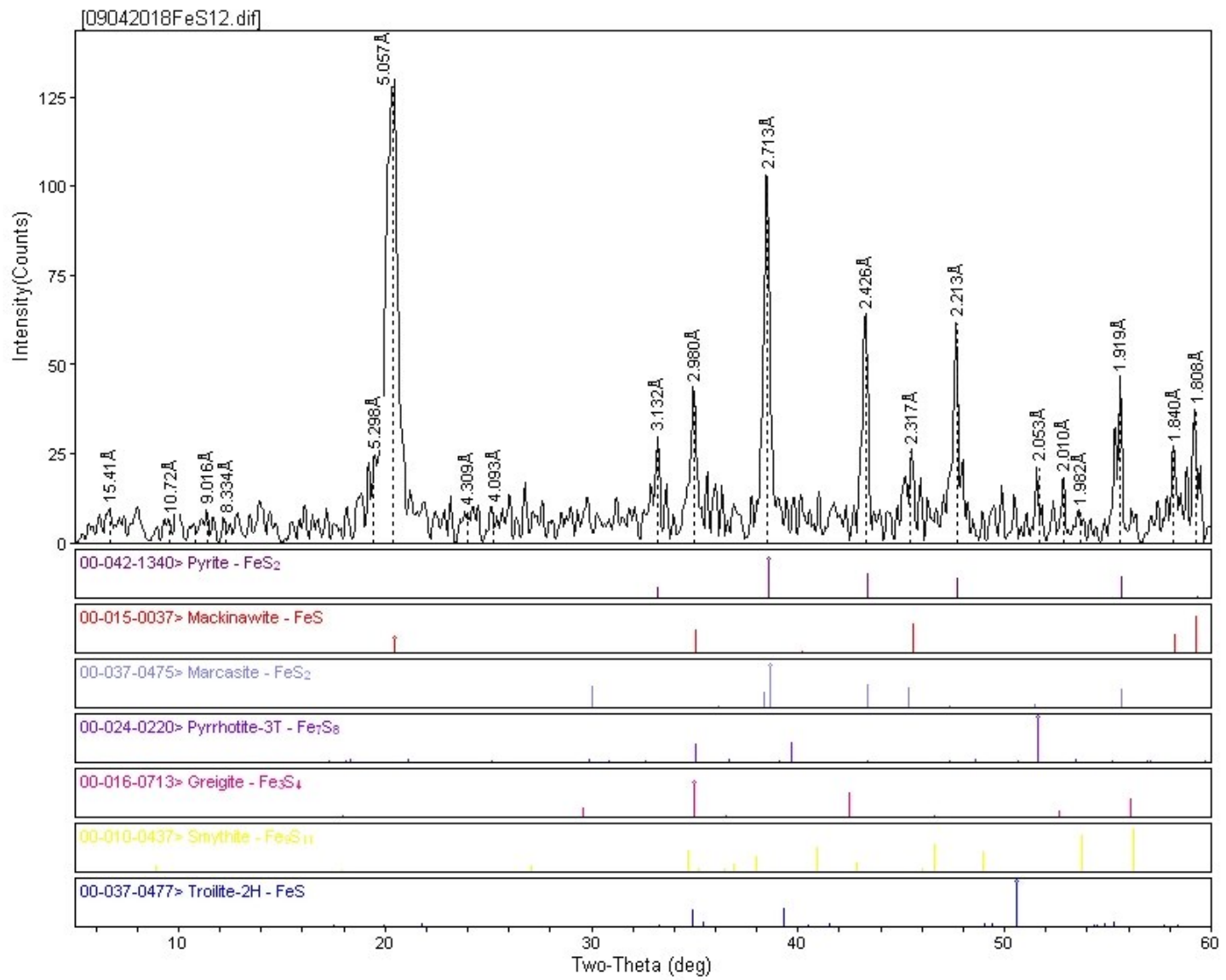

XRD pattern with background deleted of Run ID 09042018 - 3360-minute extraction. $50^{\circ} \mathrm{C}$ without organics. 


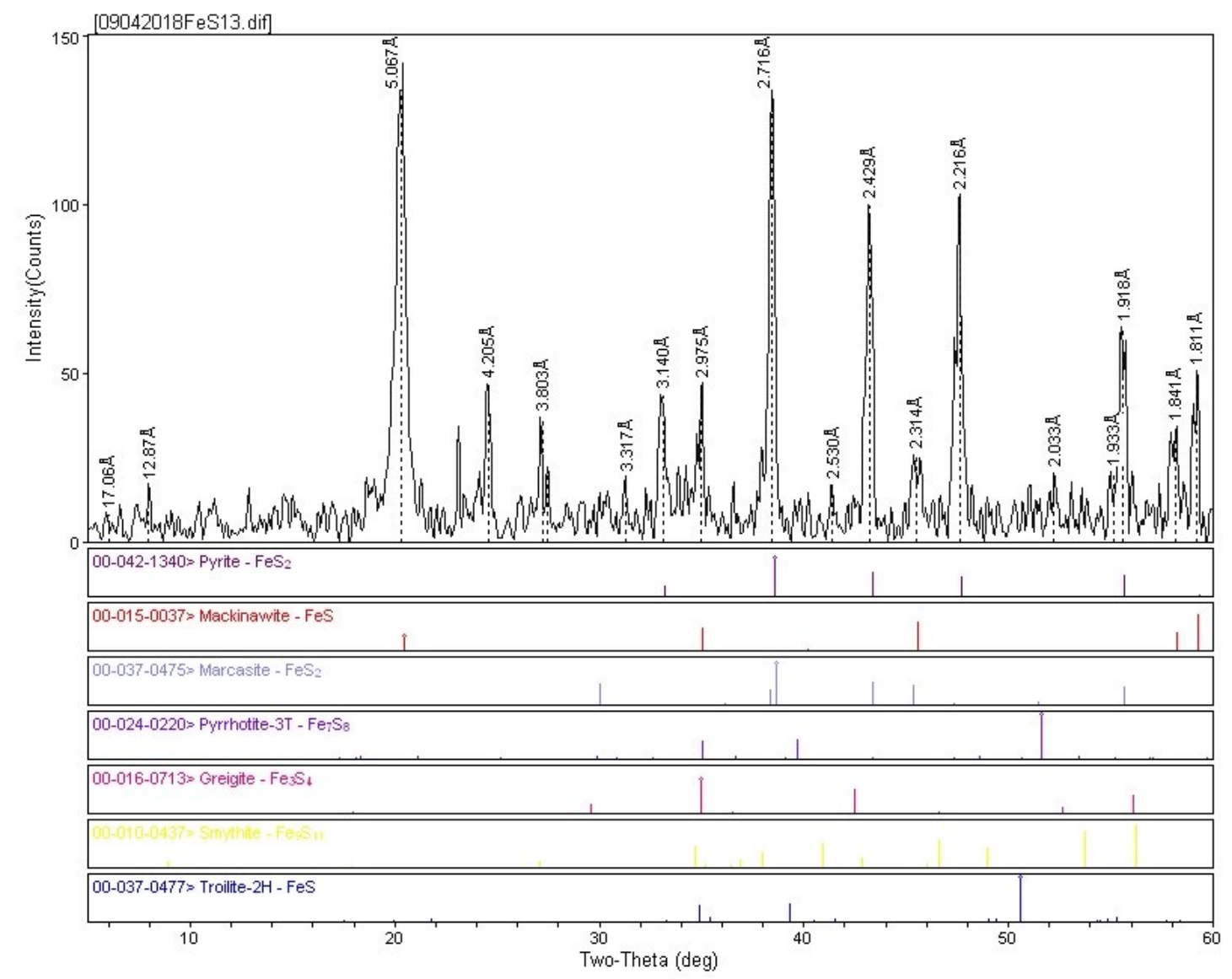

XRD pattern with background deleted of Run ID 09042018 - 4080-minute extraction. $50^{\circ} \mathrm{C}$ without organics. Image produced in Jade by Joseph A. Nolan. 


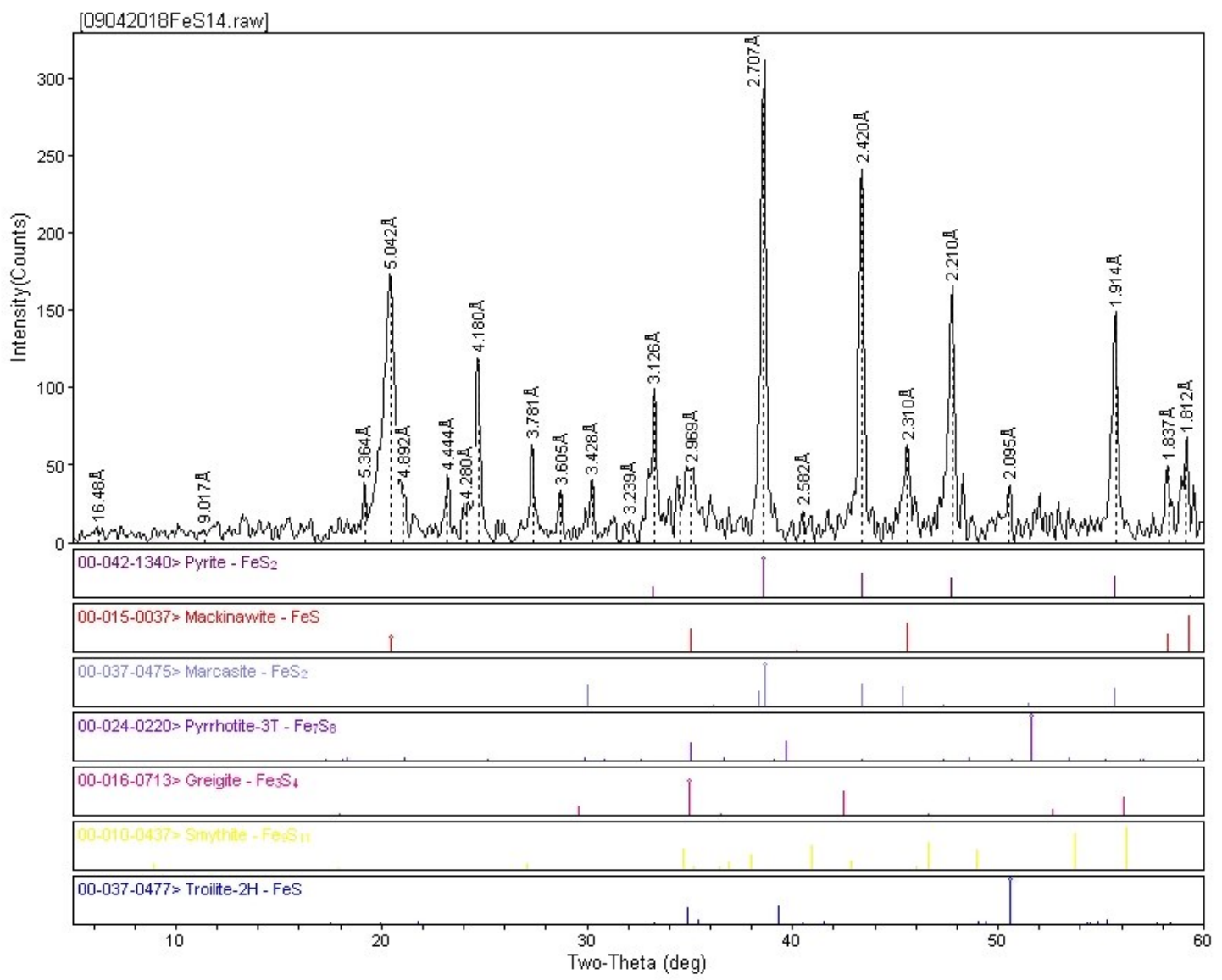

XRD pattern with background deleted of Run ID 09042018 - 4680-minute extraction. $50^{\circ} \mathrm{C}$ without organics. 


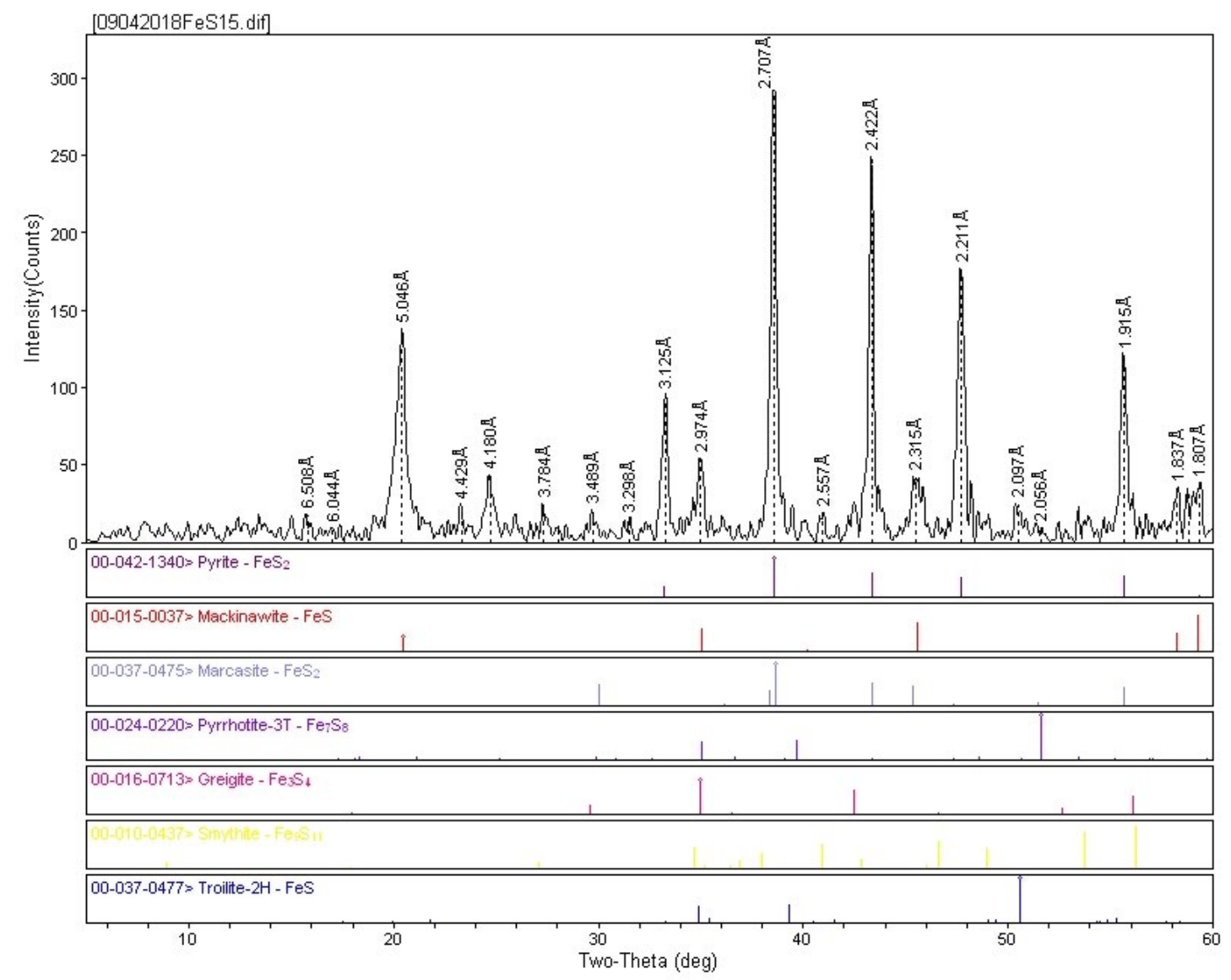

XRD pattern with background deleted of Run ID 09042018 - 5520-minute extraction. 


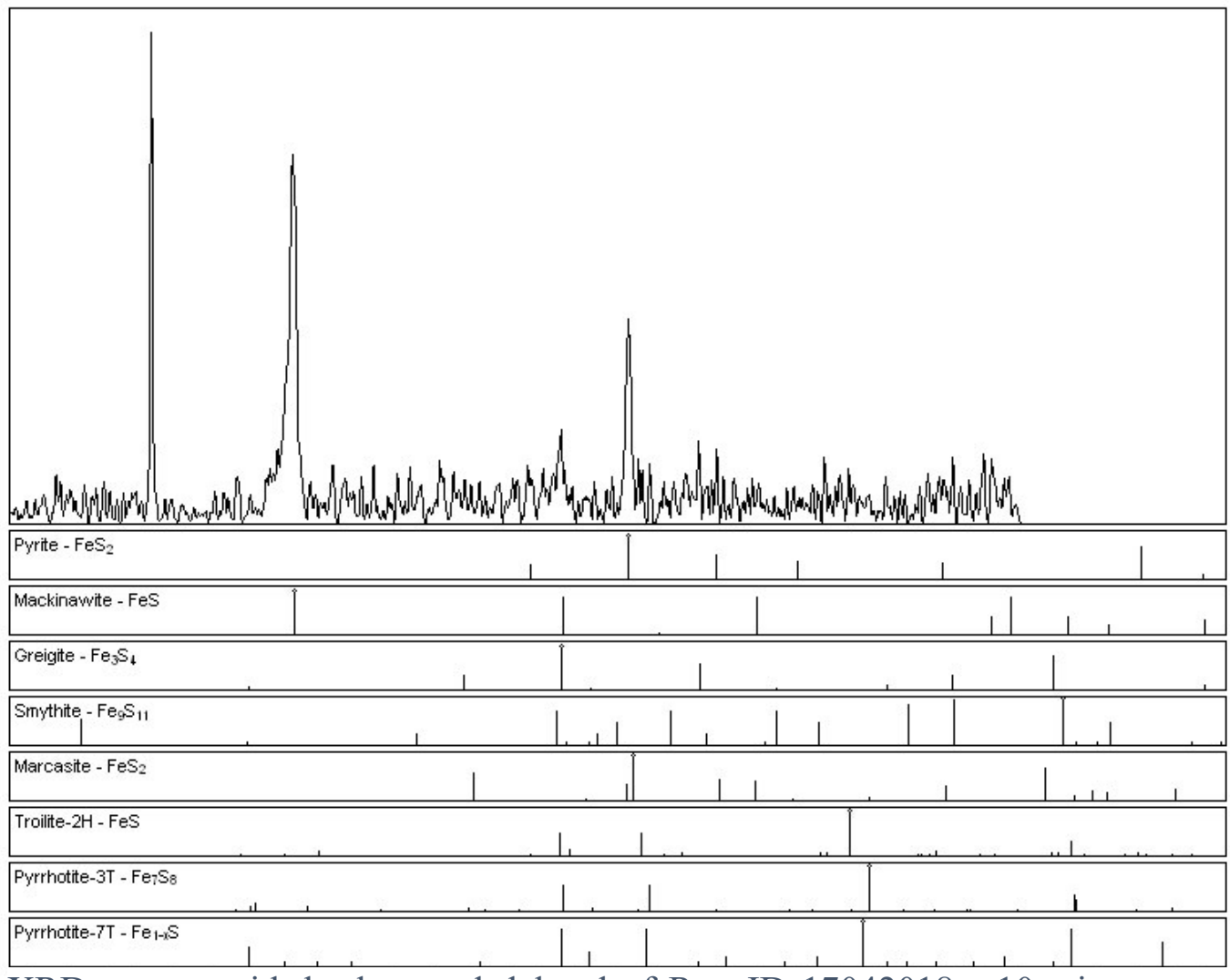

XRD pattern with background deleted of Run ID 17042018 - 10-minute extraction. $20^{\circ} \mathrm{C}$ without organics. 


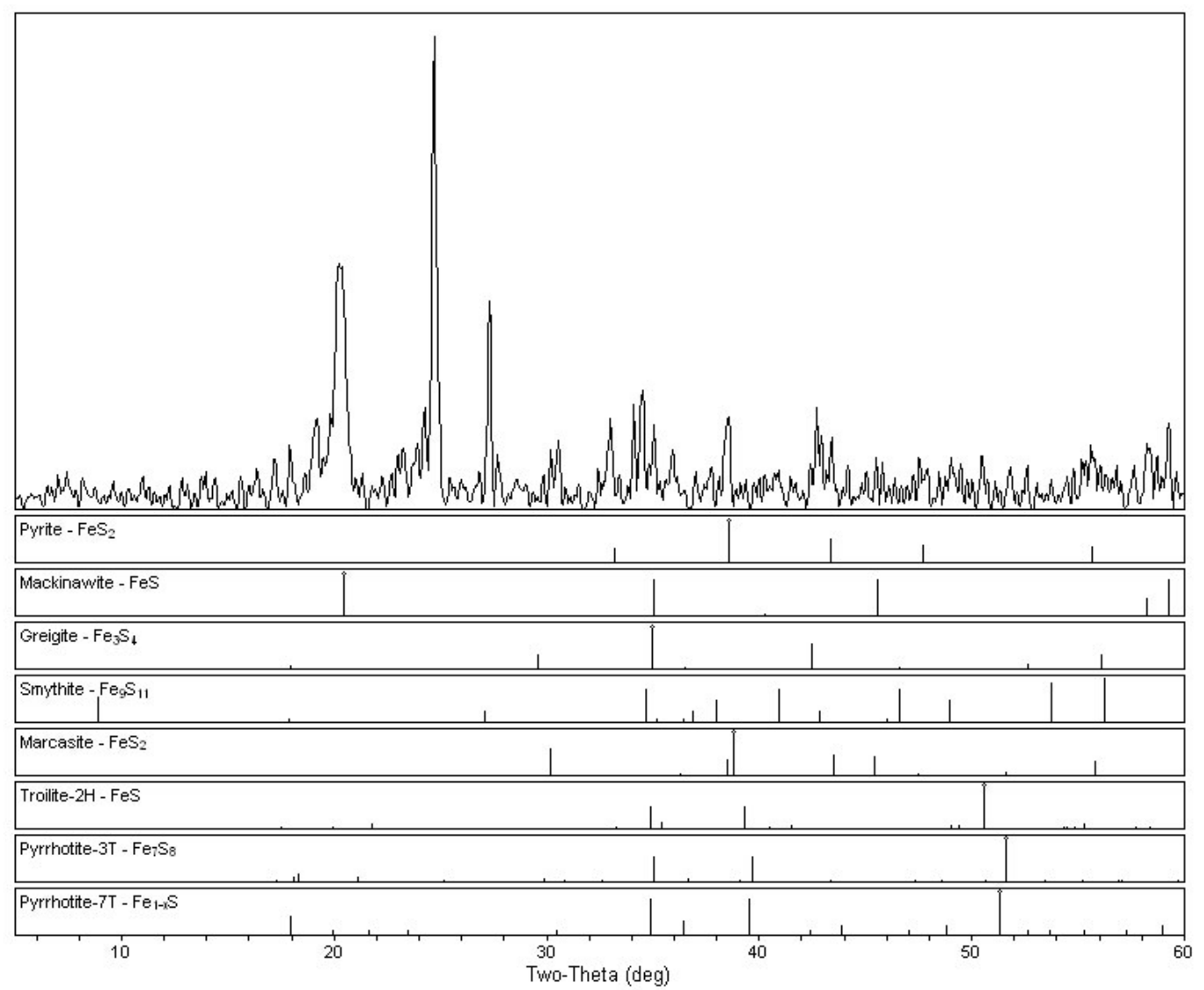

XRD pattern with background deleted of Run ID 17042018 - 90-minute extraction. $20^{\circ} \mathrm{C}$ without organics. 


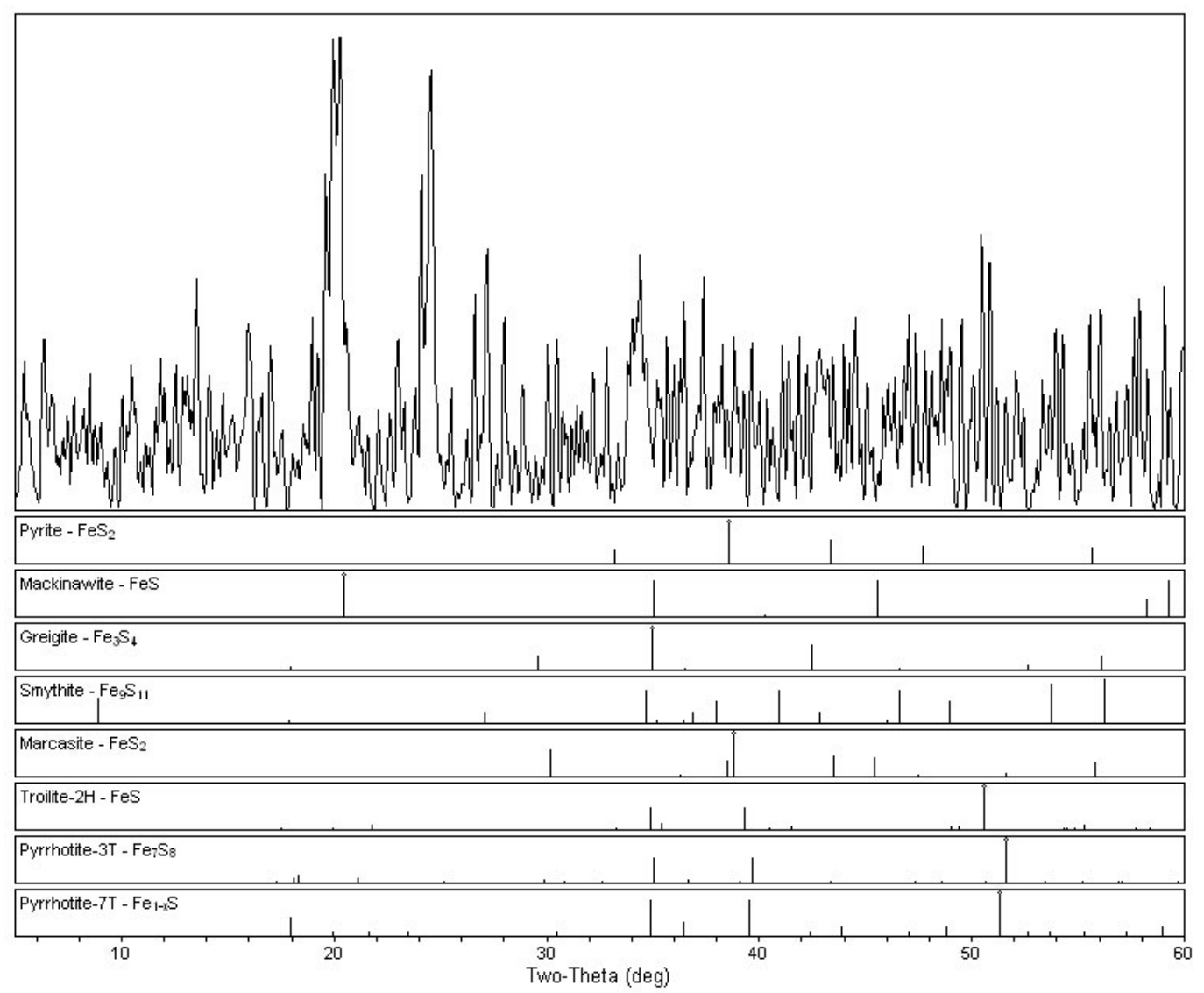

XRD pattern with background deleted of Run ID 17042018 - 60-minute extraction. $20^{\circ} \mathrm{C}$ without organics. 


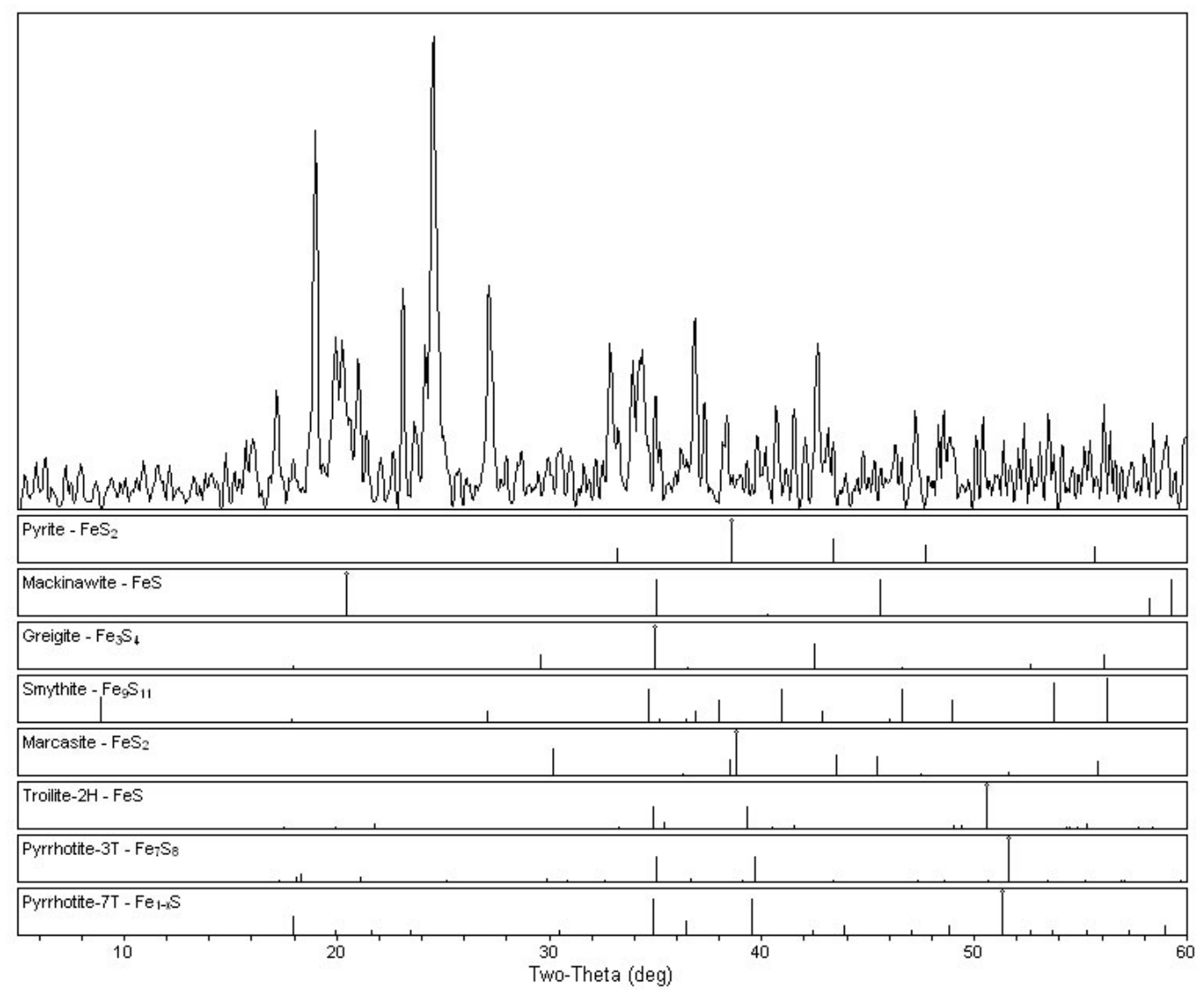

XRD pattern with background deleted of Run ID 17042018 - 120-minute extraction. $20^{\circ} \mathrm{C}$ without organics. 


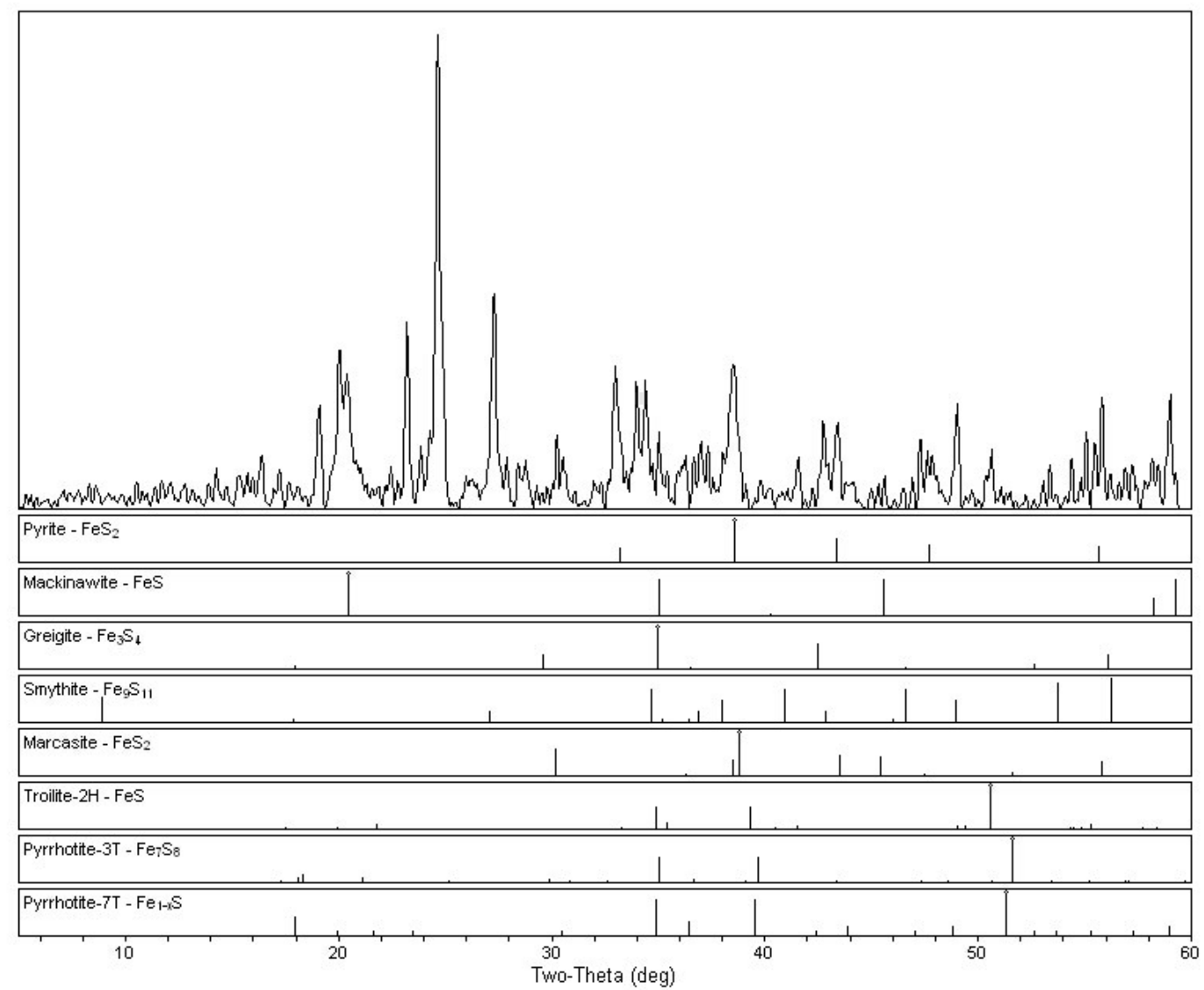

XRD pattern with background deleted of Run ID 17042018 - 240-minute extraction. $20^{\circ} \mathrm{C}$ without organics. 


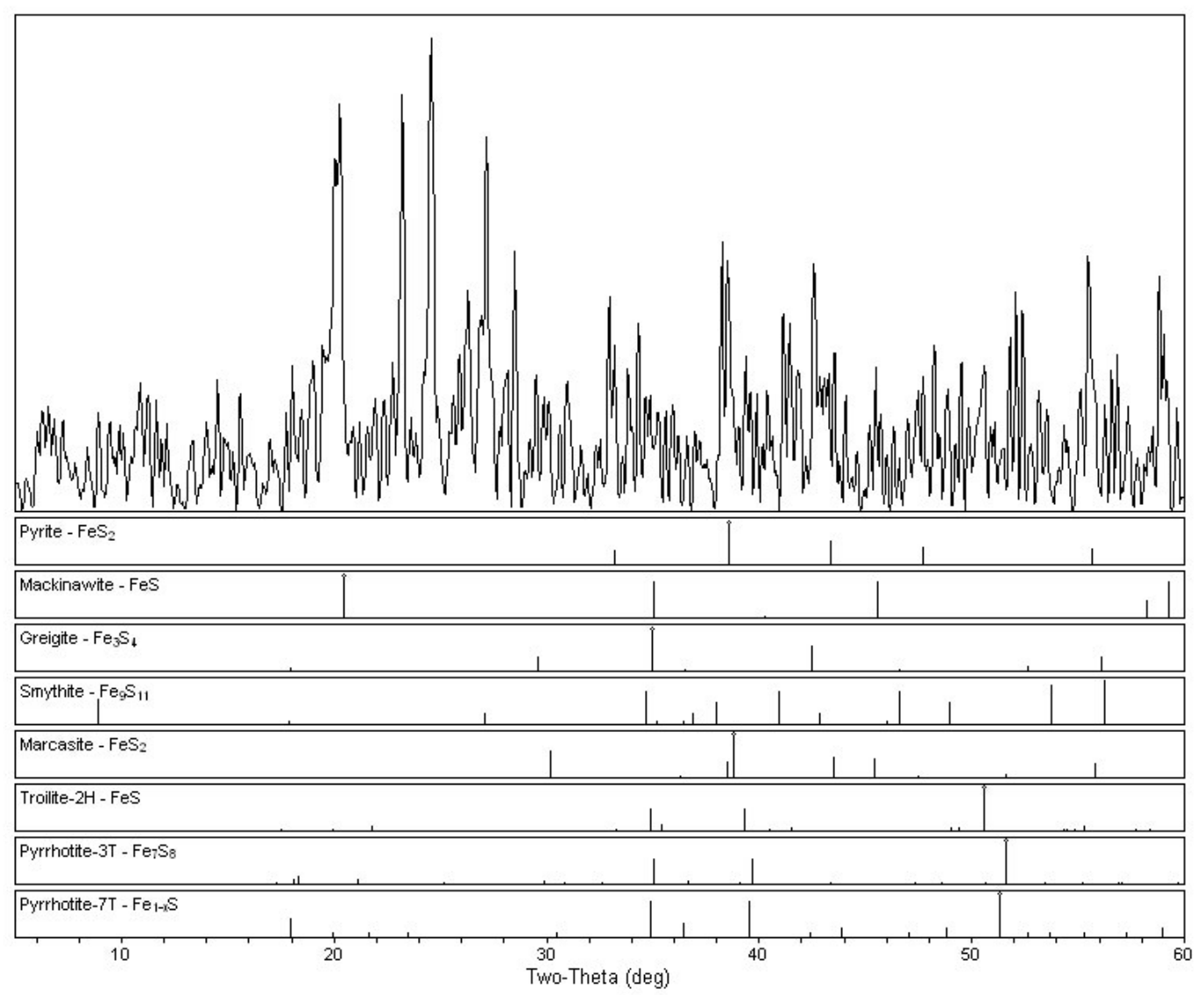

XRD pattern with background deleted of Run ID 17042018 - 480-minute extraction. $20^{\circ} \mathrm{C}$ without organics. 


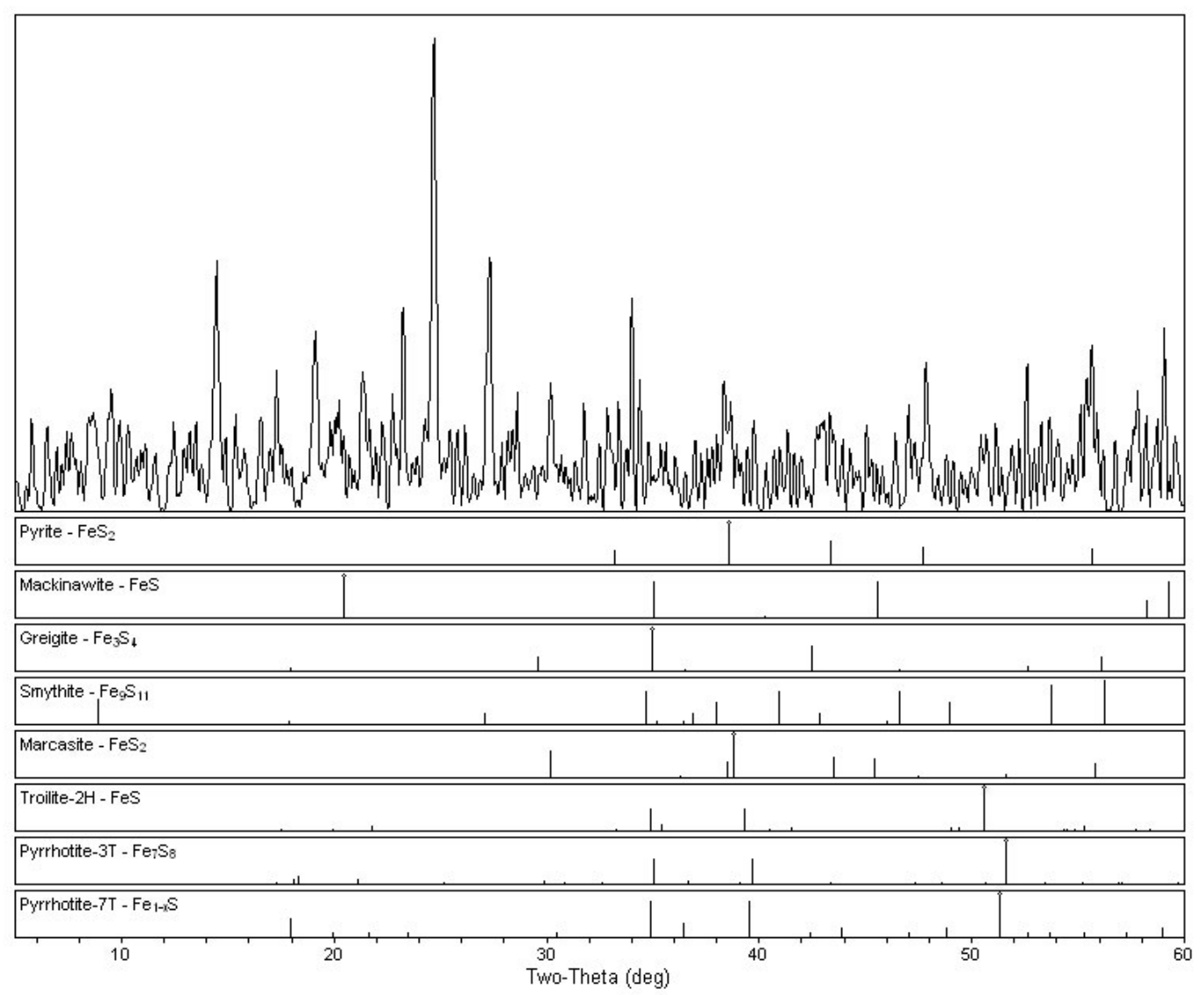

XRD pattern with background deleted of Run ID 17042018 - 960-minute extraction. $20^{\circ} \mathrm{C}$ without organics. 


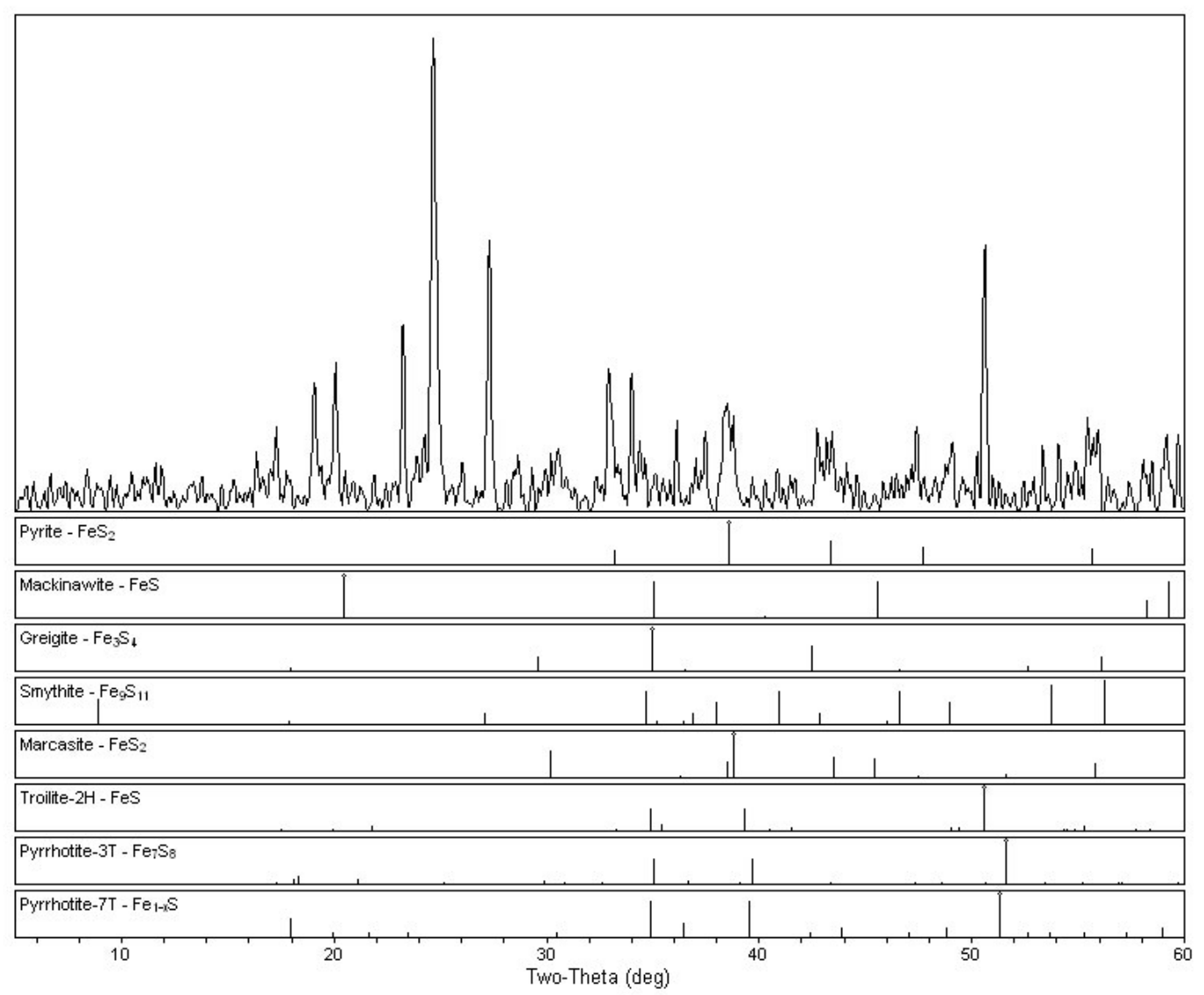

XRD pattern with background deleted of Run ID 17042018 - 1440-minute extraction. $20^{\circ} \mathrm{C}$ without organics. 


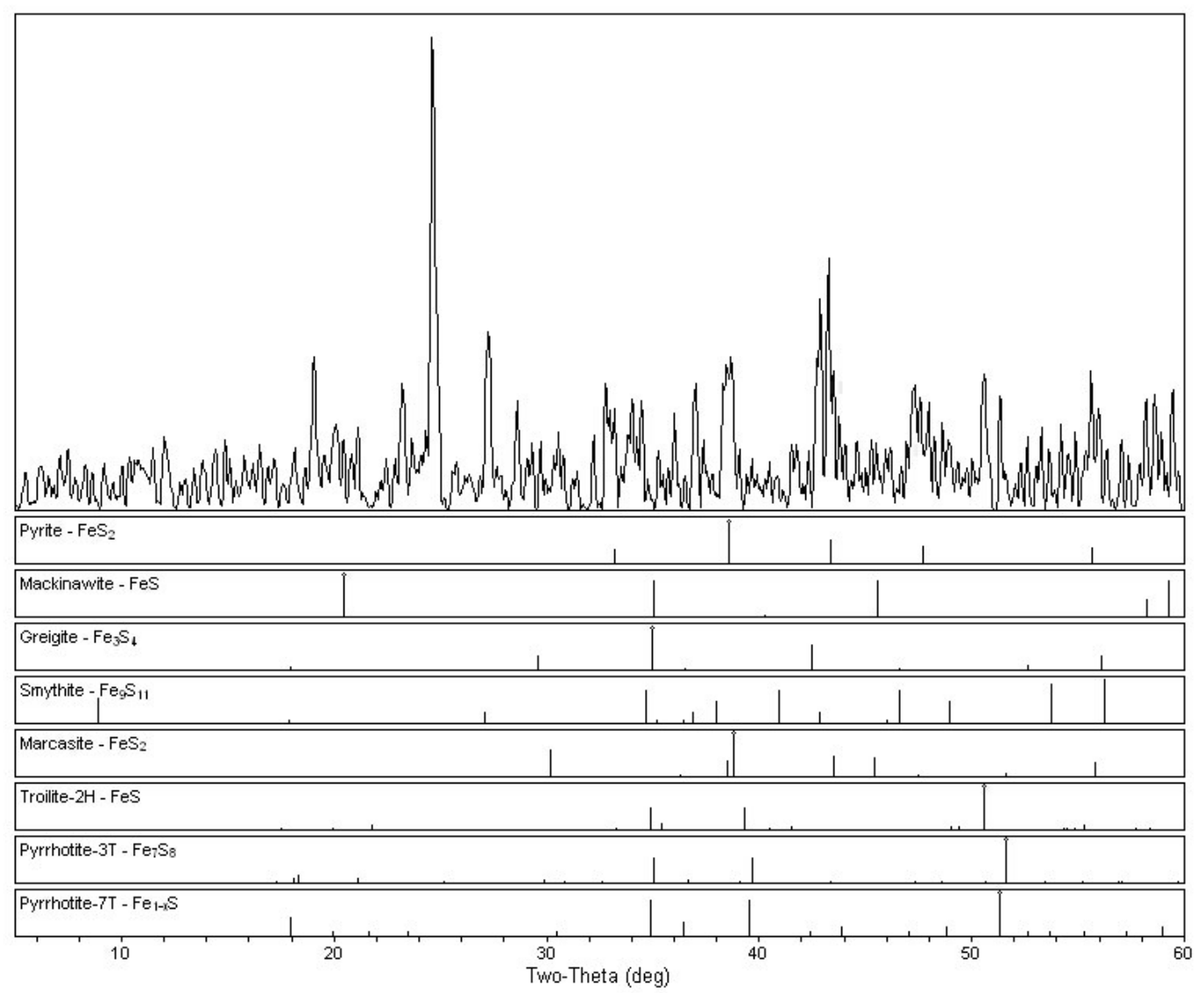

XRD pattern with background deleted of Run ID 17042018 - 1920-minute extraction. $20^{\circ} \mathrm{C}$ without organics. 


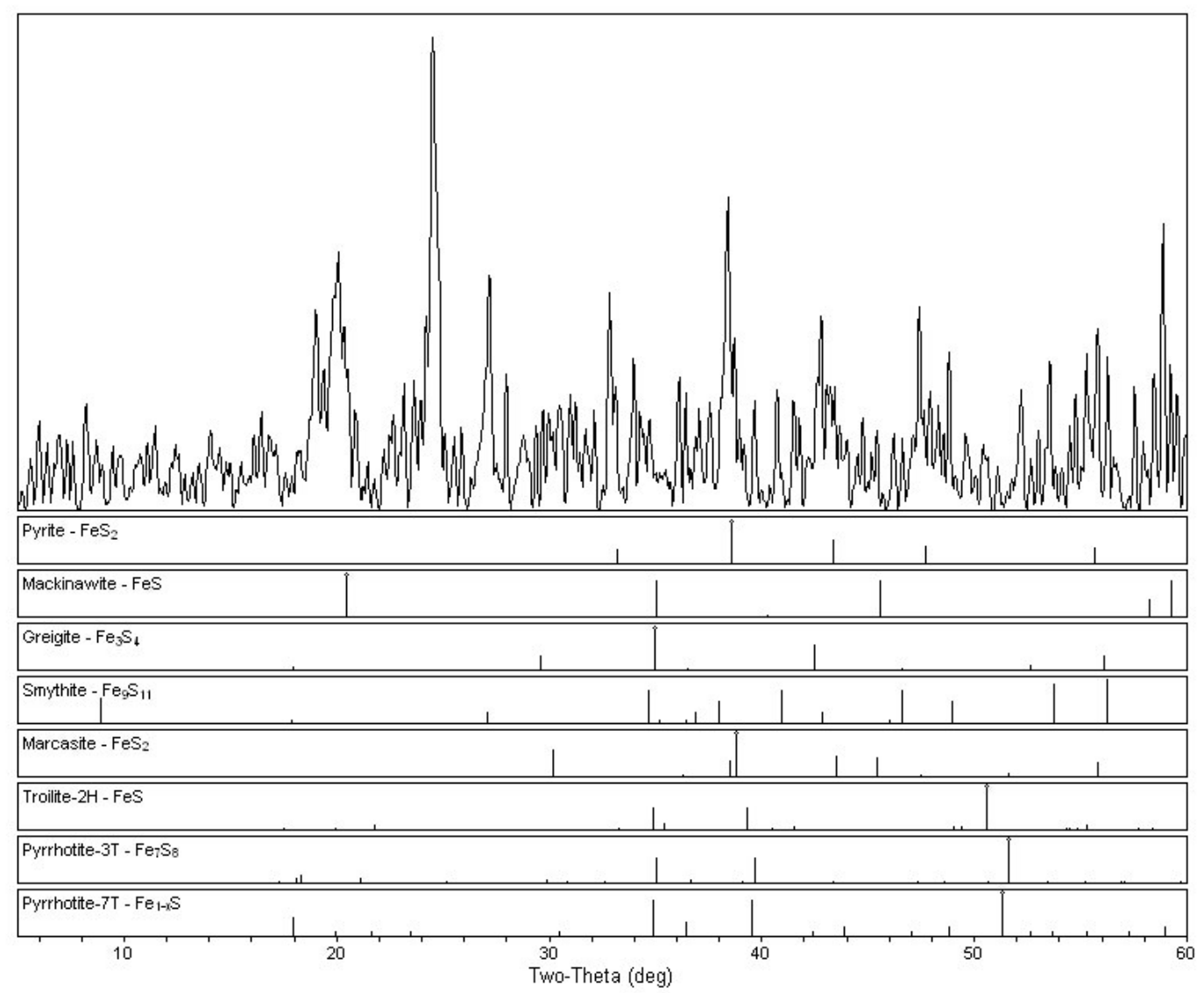

XRD pattern with background deleted of Run ID 17042018 - 2400-minute extraction. $20^{\circ} \mathrm{C}$ without organics. 


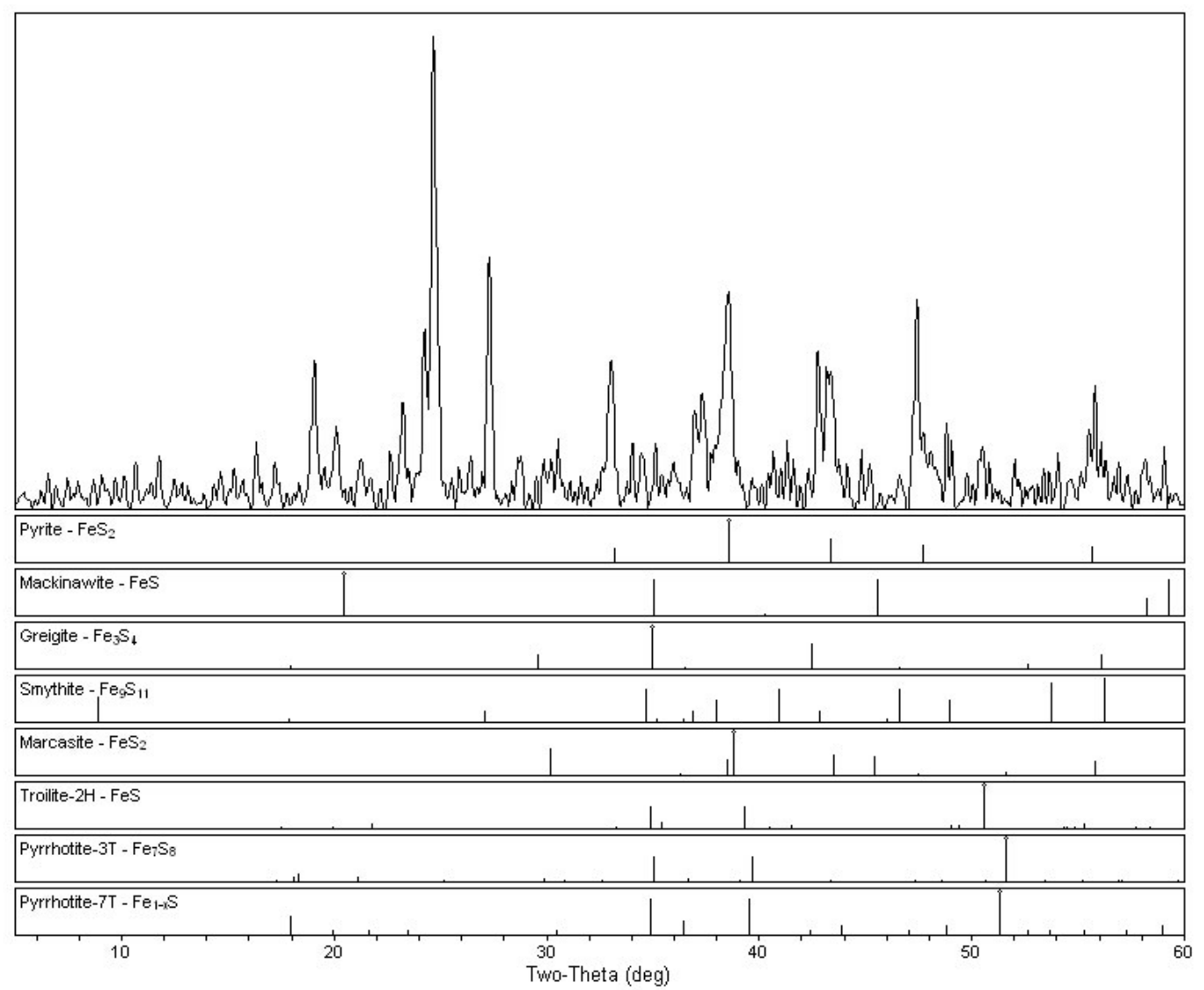

XRD pattern with background deleted of Run ID 17042018 - 2880-minute extraction. $20^{\circ} \mathrm{C}$ without organics. 


\section{REFERENCES}

Anthony, J.W., Bideaux, R.A., Bladh, K.W., and Nichols, C.M. (Eds.), 2001, Pyrite, in Handbook of Mineralogy, Chantilly, VA, Mineralogical Society of America, p. 2005, http://www.handbookofmineralogy.org/.

Appelo, C. a J., and Postma, D., 2005, Geochemistry, groundwater and pollution: Amsterdam, A.A. Balkema Publishers, 647 p.

Arakaki, A., Nakazawa, H., Nemoto, M., Mori, T., and Matsunaga, T., 2008, Formation of magnetite by bacteria and its application: Journal of The Royal Society Interface, v. 5, p. 977-999, doi:10.1098/rsif.2008.0170.

Ariztegui, D., and Dobson, J., 1996, Magnetic investigations of framboidal greigite formation: A record of anthropogenic environmental changes in eutrophic lake St Moritz, switzerland: Holocene, v. 6, p. 235-241, doi:10.1097/YCO.0000000000000159.

Armstrong, F., 1957, The iron content of Sea Water: Journal of the Marine Biological Association of the United Kingdom, v. 36, p. 509-517, doi:10.1017/S0025315400025807.

Atkinson, R., 2007, Gas-phase tropospheric chemistry of organic compounds: A review: Atmospheric Environment, v. 41, p. 200-240, doi:10.1016/j.atmosenv.2007.10.068.

Benning, L.G., Wilkin, R.T., and Barnes, H.L., 2000, Reaction pathways in the Fe-S system below $100^{\circ} \mathrm{C}$ : Chemical Geology, v. 167, p. 25-51, doi:10.1016/S0009-2541(99)001989.

Berner, R.A., 1964, Iron sulfides formed from aqueous solution at low temperatures and atmospheric pressure: The Journal of Geology, v. 72, p. 293-306, doi:10.1086/626987.

Berner, R.A., 1962, Tetragonal iron sulfide: Science, v. 137, p. 669. 
Berner, R.A., 1967, Thermodynamic stability of sedimentary iron sulfides: American Journal of Science, v. 265, p. 773-785, doi:10.2475/ajs.265.9.773.

Blakemore, R., 1975, Magnetotactic bacteria: Science, v. 190, p. 377-379.

Bourdoiseau, J.A., Jeannin, M., Rémazeilles, C., Sabot, R., and Refait, P., 2010, The transformation of mackinawite into greigite studied by raman spectroscopy: Journal of Raman Spectroscopy, v. 42, p. 496-504, doi:10.1002/jrs.2729.

Breitmaier, E., 2006, Terpenes: Importance, general structure, and biosynthesis, in Terpenes, Weinheim, Germany, Wiley-VCH Verlag GmbH \& Co. KGaA, p. 1-9, doi:10.1002/9783527609949.ch1.

Bridges, J.C., and Warren, P.H., 2006, The SNC meteorites: Basaltic igneous processes on Mars: Journal of the Geological Society, v. 163, p. 229-251, doi:10.1144/0016-764904501.

Carpenter, R.H., and Desborough, G.A., 1964, Range in solid solution and structure of naturally occurring troilite and pyrrhotite: American Mineralogist, v. 49, p. 1350.

Cox, M., and Nelson, D., 2008, Glycolysis, gluconeogenesis, and the pentose phosphate pathway, in Lehninger Principles of Biochemistry, New York, NY, W H Freeman \& Co., p. 527-568.

Devouard, B., Pósfai, M., Hua, X., Bazylinski, D.A., Frankel, R.B., and Buseck, P.R., 1998, Magnetite from magnetotactic bacteria: size distributions and twinning: American Mineralogist, v. 83, p. 1387-1398.

Doebelin, N., and Kleeberg, R., 2015, Profex: A graphical user interface for the rietveld refinement program BGMN: Journal of Applied Crystallography, v. 48, p. 1573-1580, doi:10.1107/S1600576715014685. 
Erd, R.C., Evans, H.T., and Richter, D.H., 1957, Smythite, a new iron sulfide, and associated pyrrhotite from Indiana: The American Mineralogist, v. 42, p. 309-333.

Fleet, M.E., 1982, Synthetic smythite and monoclinic $\mathrm{Fe}_{3} \mathrm{~S}_{4}$ : Physics and Chemistry of Minerals, v. 8, p. 241.

Forbes, S.L., and Perrault, K.A., 2014, Decomposition odour profiling in the air and soil surrounding vertebrate carrion: PLoS ONE, v. 9, p. 21-22, doi:10.1371/journal.pone.0095107.

Frankel, R.B., Dunin-Borkowski, R.E., Posfai, M., and Bazylinski, D.A., 2008, Magnetic microstructure of magnetotactic bacteria: Handbook of Biomineralization: Biological Aspects and Structure Formation, v. 1, p. 126-144, doi:10.1002/9783527619443.ch8.

Gelmont, D., Stein, R.A., and Mead, J.F., 1981, Isoprene - The main hydrocarbon in human breath: Biochemical and Biophysical Research Communications, v. 99, p. 1456-1460, doi:10.1016/0006-291X(81)90782-8.

Gevantman, L.H., 2015, Solubility of selected gases in water: CRC Handbook of Chemistry and Physics, p. 5-8, doi:10.1021/je60054a024.

El Goresy, A., Yabuki, H., Ehlers, K., Woolum, D., and Pernicka, E., 1988, Qingzhen and Yamato-691: A tentative alphabet for the EH chondrites: Proceedings of the National Institute of Polar Research Symposium Antarctic Meteorite Research Center, v. 1, p. 65-101.

Herbert, R.B., Benner, S.G., Pratt, A.R., and Blowes, D.W., 1998, Surface chemistry and morphology of poorly crystalline iron sulfides precipitated in media containing sulfatereducing bacteria: Chemical Geology, v. 144, p. 87-97, doi:10.1016/S00092541(97)00122-8. 
Van Hoof, F., Wittocx, A., Van Buggenhout, E., and Janssens, J., 1985, Determination of aliphatic aldehydes in waters by high-performance liquid chromatography: Analytica Chimica Acta, v. 169, p. 419-424, doi:10.1016/S0003-2670(00)86251-0.

Horng, C.S., and Roberts, A.P., 2006, Authigenic or detrital origin of pyrrhotite in sediments?: resolving a paleomagnetic conundrum: Earth and Planetary Science Letters, v. 241, p. 750-762, doi:10.1016/j.eps1.2005.11.008.

Horng, C.S., Torii, M., Shea, K.S., and Kao, S.J., 1998, Inconsistent magnetic polarities between greigite- and pyrrhotite/magnetite-bearing marine sediments from the Tsailiaochi section, southwestern Taiwan: Earth and Planetary Science Letters, v. 164, p. 467481, doi:10.1016/S0012-821X(98)00239-8.

Hunger, S., and Benning, L.G., 2007, Greigite: a true intermediate on the polysulfide pathway to pyrite: Geochemical Transactions, v. 8, p. 1-20, doi:10.1186/1467-4866-8-1.

Ivancev-Tumbas, I., and Dalmacija, B., 2001, Effects of coagulation processes on aldehydes formation in groundwater treated with common oxidative agents: Water Research, v. 35, p. 3950-3958, doi:10.1016/S0043-1354(01)00111-7.

Jiang, W.T., Horng, C.S., Roberts, A.P., and Peacor, D.R., 2001, Contradictory magnetic polarities in sediments and variable timing of neoformation of authigenic greigite: Earth and Planetary Science Letters, v. 193, p. 1-12, doi:10.1016/S0012-821X(01)00497-6.

Kesselmeier, J., and Staudt, M., 1999, Biogenic volatile organic compounds (VOC): an overview on emission, physiology and ecology: Journal of Atmospheric Chemistry, v. 33, p. 23-88, doi:10.1023/A:1006127516791.

King, J., Koc, H., Unterkofler, K., Mochalski, P., Kupferthaler, A., Teschl, G., Teschl, S., Hinterhuber, H., and Amann, A., 2010, Physiological modeling of isoprene dynamics in 
exhaled breath: Journal of Theoretical Biology, v. 267, p. 626-637, doi:10.1016/J.JTBI.2010.09.028.

Kotzias, D., Konidari, C., and Sparta, C., 1997, Volatile carbonyl compounds of biogenic origin - emission and concentration in the atmosphere: Biogenic volatile organic compounds in the atmosphere1, p. 67-78.

Krupp, R.E., 1994, Phase relations and phase transformations between the low-temperature iron sulfides mackinawite, greigite, and smythite: European Journal of Mineralogy, v. 6, p. 265-278, doi:10.1127/ejm/6/2/0265.

Kuykendall, J.R., 2010, Aldehydes, in Comprehensive Toxicology, Elsevier, p. 291-330, doi:10.1016/B978-0-08-046884-6.00916-7.

Laidler, K.J., 1984, The development of the Arrhenius equation: Journal of Chemical Education, v. 61, p. 494, doi:10.1021/ed061p494.

Larrasoaña, J.C., Roberts, A.P., Musgrave, R.J., Gràcia, E., Piñero, E., Vega, M., and Martínez-Ruiz, F., 2007, Diagenetic formation of greigite and pyrrhotite in gas hydrate marine sedimentary systems: Earth and Planetary Science Letters, v. 261, p. 350-366, doi:10.1016/j.epsl.2007.06.032.

Lennie, A.R., England, K.E.R., and Vaughan, D.J., 1995, Transformation of synthetic mackinawite to hexagonal pyrrhotite: a kinetic study: American Mineralogist, v. 80, p. 960-967.

Lennie, A., Redfern, S.A., Champness, P.E., Stoddart, C., Schofield, P.., and Vaughan, D.J., 1997, Transformation of mackinawite to greigite: an in situ x-ray powder diffraction and transmission electron microscope study: American Mineralogist, v. 82, p. 302-309.

Li, C., Yang, S., Lian, E., Wang, Q., Fan, D., and Huang, X., 2017, Chemical speciation of 
iron in sediments from the Changjiang estuary and east China sea: iron cycle and paleoenvironmental implications: Quaternary International, v. 452, p. 116-128, doi:10.1016/j.quaint.2016.07.014.

Liao, T., Wang, W., Song, Y., Wang, X., Yang, Y., and Liu, X., 2015, HMTA-assisted onepot synthesis of greigite nano-platelet and its magnetic properties: Journal of Materials Science and Technology, v. 31, p. 895-900, doi:10.1016/j.jmst.2015.07.006.

Lin, M.-Y., Chen, Y.-H., Lee, J.-J., and Sheu, H.-S., 2018, Reaction pathways of iron-sulfide mineral formation: an in situ x-ray diffraction study: European Journal of Mineralogy, v. 30, p. 77-84, doi:10.1127/ejm/2017/0029-2681.

Lloyd, A.C., Atkinson, R., Lurmann, F.W., and Nitta, B., 1983, Modeling potential ozone impacts from natural hydrocarbons-I. Development and testing of a chemical mechanism for the nox-air photooxidations of isoprene and $\alpha$-pinene under ambient conditions: Atmospheric Environment (1967), v. 17, p. 1931-1950, doi:10.1016/00046981(83)90351-7.

Mann, S., Sparks, N.H.C., Frankel, R.B., Bazylinski, D.A., and Jannasch, H.W., 1990, Biomineralization of ferrimagnetic greigite $\left(\mathrm{Fe}_{3} \mathrm{~S}_{4}\right)$ and iron pyrite $\left(\mathrm{FeS}_{2}\right)$ in a magnetotactic bacterium: Nature, v. 343, p. 258-261, doi:10.1038/343258a0.

McKay, D.S., Gibson, E.K., Thomas-Keprta, K.L., Vali, H., Romanek, C.S., Clemett, S.J., Chillier, X.D., Maechling, C.R., and Zare, R.N., 1996, Search for past life on Mars: possible relic biogenic activity in martian meteorite ALH84001: Science (New York, N.Y.), v. 273, p. 924-930, doi:10.1126/science.273.5277.924.

Menyeh, A., and O'Reilly, W., 1995, The coercive force of fine particles of monoclinic pyrrhotite $\left(\mathrm{Fe}_{7} \mathrm{~S}_{8}\right)$ studied at elevated temperature: Physics of the Earth and Planetary 
Interiors, p. 51-62.

Menyeh, A., and O'Reilly, W., 1991, The magnetization process In monoclinic pyrrhotite $\left(\mathrm{Fe}_{7} \mathrm{~S}_{8}\right)$ particles containing few domains: Geophysical Journal International, v. 104, p. 387-399, doi:10.1111/j.1365-246X.1991.tb02519.x.

Meyer, F.H., Riggs, O.L., McGlasson, R.L., and Sudbury, J.D., 1958, Corrosion Products of Mild Steel In Hydrogen Sulfide Environments: Corrosion Science, v. 14, p. 69-75, doi:10.5006/0010-9312-14.2.69.

Millet, D.B., 2011, Global atmospheric budget of acetaldehyde: 3-d model analysis and constraints from in-situ and satellite observations, in Aldehydes: Advances in Research and Application, Science, p. 38.

Milton, C., 1966, "Kansite” = mackinawite, FeS: Corrosion Science, v. 22, p. 191-193, doi:10.5006/0010-9312-22.7.191.

Mortimer, C., 1941, The exchange of dissolved substances between mud and water in lakes: Journal of Ecology, v. 29, p. 280-329, doi:10.2307/2256395.

Murowchick, J.B., 1992, Marcasite inversion and the petrographic determination of pyrite ancestry: v. 87, p. $1141-1152$.

Murowchick, J.B., and Barnes, H.L., 1987, Effects of temperature and degree of supersaturation on pyrite morphology: American Mineralogist, v. 72, p. 24-1250, http://www.minsocam.org/ammin/AM72/AM72_1241.pdf.

Murowchick, J.B., and Barnes, H.L., 1986, Formation of cubic FeS: American Mineralogist, v. 71, p. $1243-1246$.

Murray, J.W., Jannasch, H.W., Honjo, S., Anderson, R.F., Reeburgh, W.S., Top, Z., Friedrich, G.E., Codispoti, L.A., and Izdar, E., 1989, Unexpected changes in the 
oxic/anoxic interface in the Black sea: Nature, v. 342, p. 189-92, doi:10.1038/340301a0.

Neal, A., Techkarnjanaruk, S., Dohnalkova, A., McCready, D., Peyton, B., and G., G., 2001, Iron sulfides and sulfur species produced at hematite surfaces in the presence of sulfatereducing bacteria: Geochimica et Cosmochimica Acta, v. 65, p. 223-235, doi:10.3109/00365515109060607.

Nickel, E.H., 1979, Mineral chemistry of metal sulfides: Mineralogical Magazine, v. 43, p. 186-187, doi:10.1180/minmag.1979.043.325.27.

Otson, R., and Fellin, P., 1988, A review of techniques for measurement of airborne aldehydes: The Science of the Total Environment, v. 77, p. 95-131.

Paolella, A. et al., 2011, Charge transport and electrochemical properties of colloidal greigite $\left(\mathrm{Fe}_{3} \mathrm{~S}_{4}\right)$ nanoplatelets: Chemistry of Materials, v. 23, p. 3762-3768, doi:10.1021/cm201531h.

Peña, R.M., García, S., Herrero, C., Losada, M., Vázquez, A., and Lucas, T., 2002, Organic acids and aldehydes in rainwater in a northwest region of Spain: Atmospheric Environment, v. 36, p. 5277-5288, doi:10.1016/S1352-2310(02)00648-9.

Planavsky, N.J., McGoldrick, P., Scott, C.T., Li, C., Reinhard, C.T., Kelly, A.E., Chu, X., Bekker, A., Love, G.D., and Lyons, T.W., 2011, Widespread iron-rich conditions in the mid-proterozoic ocean: Nature, v. 477, p. 448-451, doi:10.1038/nature10327.

Pósfai, M., Buseck, P.R., Bazylinski, D.A., and Frankel, R.B., 1998, Iron sulfides from magnetotactic bacteria: structure, composition, and phase transitions: American Mineralogist, v. 83, p. 1469-1481, doi:10.2138/am-1998-11-1235.

Poulton, S.W., and Canfield, D.E., 2011, Ferruginous conditions: a dominant feature of the 
ocean through Earth's history: Elements, v. 7, p. 107-112, doi:10.2113/gselements.7.2.107.

Preisinger, A., Aslanian, S., and Wernisch, J., 2012, Biogreigites $\left(\mathrm{Fe}_{3} \mathrm{~S}_{4}\right)$ in sea water sediments and their paleohydrological applications: Water Resources, v. 39, p. 335-343, doi:10.1134/S0097807812030098.

Raiswell, R., Buckley, F., Berner, R.A., and Anderson, T.F., 1988, Degree of pyritization of iron as a paleoenvironmental indicator of bottom-water oxygenation: Journal of Sedimentary Research, v. 58, p. 812-819, doi:10.1306/212F8E72-2B24-11D7$8648000102 \mathrm{C} 1865 \mathrm{D}$.

Revsbech, N.P., Jorgensen, B.B., and Brix, O., 1981, Primary production of microalgae in

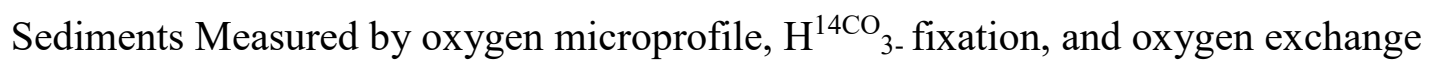
methods: Limnology and Oceanography, v. 26, p. 717-730.

Rickard, D., 1969, The chemistry of iron sulphide formation at low temperatures: Stockholm contributions to geology, v. 20, p. 67-95.

Rickard, D., Butler, I.B., and Oldroyd, A., 2001, A novel iron sulphide mineral switch and its implications for Earth and planetary science: Earth and Planetary Science Letters, v. 189, p. 85-91, doi:10.1016/S0012-821X(01)00352-1.

Rickard, D., and Luther, G.W., 2007, Chemistry of iron sulfides: v. 107, 514-562 p., doi:10.1021/cr0503658.

Rickard, D., and Luther, G.W., 1997, Kinetics of pyrite formation by the $\mathrm{H}_{2} \mathrm{~S}$ oxidation of iron(II) monosulfide in Aqueous Solutions between 25 and 125 degrees C: the rate equation: Geochimica et Cosmochimica Acta, v. 61, p. 135-147, doi:doi:10.1016/S0016-7037(96)00321-3. 
Rickard, D., and Morse, J.W., 2005, Acid volatile sulfide (AVS): v. 97, 141-197 p., doi:10.1016/j.marchem.2005.08.004.

Rimstidt, J.D., 2013, Geochemical Rate Models: Cambridge, Cambridge University Press, doi:10.1017/CBO9781139342773.

Roberts, A.P., 1995, Magnetic properties of sedimentary gregite $\left(\mathrm{Fe}_{3} \mathrm{~S}_{4}\right)$ : Earth and Planetary Science Letters, v. 134, p. 227-236, doi:10.1016/0012-821X(95)00131-U.

Roberts, A.P., Liu, Q., Rowan, C.J., Chang, L., Carvallo, C., Torrent, J., and Horng, C.S., 2006, Characterization of hematite $\left(\alpha-\mathrm{Fe}_{2} \mathrm{O}_{3}\right)$, goethite $(\alpha-\mathrm{FeOOH})$, greigite $\left(\mathrm{Fe}_{3} \mathrm{~S}_{4}\right)$, and pyrrhotite $\left(\mathrm{Fe}_{7} \mathrm{~S}_{8}\right)$ using first-order reversal curve diagrams: Journal of Geophysical Research: Solid Earth, v. 111, p. 1-16, doi:10.1029/2006JB004715.

Rochette, P., Lorand, J., Fillion, G., and Sautter, V., 2001, Pyrrhotite and the remanent magnetization of SNC meteorites: a changing perspective on martian magnetism: Earth and Planetary Science Letters, v. 190, p. 1-12.

Ron, H., Nowaczyk, N.R., Frank, U., Schwab, M.J., Naumann, R., Striewski, B., and Agnon, A., 2007, Greigite detected as dominating remanence carrier in late pleistocene sediments, lisan formation, from lake Kinneret (sea of Galilee), Israel: Geophysical Journal International, v. 170, p. 117-131, doi:10.1111/j.1365-246X.2007.03425.x.

Rouxel, O.J., Bekker, A., and Edwards, K.J., 2005, Iron Isotope Constraints on the Archean and Paleoproterozoic Ocean Redox State: Science, v. 307, p. 1088-1092, doi:10.1126/science.1105692.

Roychoudhury, A.N., Kostka, J.E., and Van Cappellen, P., 2003, Pyritization: a palaeoenvironmental and redox proxy reevaluated: Estuarine, Coastal and Shelf Science, v. 57, p. 1183-1193, doi:10.1016/S0272-7714(03)00058-1. 
Sakugawa, H., Kaplan, I.R., and Shepard, L.S., 1993, Measurements of H2O2, aldehydes and organic acids in Los Angeles rainwater: their sources and deposition rates: Atmospheric Environment. Part B, Urban Atmosphere, v. 27, p. 203-219, doi:10.1016/09571272(93)90006-R.

Schieber, J., 2011, Iron sulfide formation, in Thiel, V., Reitner, J., Reid, P., Kappler, A., Fritz, H.W., Zhang, X., and Konhauser, K. eds., Encyclopedia of Geobiology, Netherlands, Springer Netherlands, p. 486-502.

Schwandner, F., 2002, The organic chemistry of volcanic gases at Vulcano (Aeolian Islands, Italy).

Scott, C., Lyons, T.W., Bekker, A., Shen, Y., Poulton, S.W., Chu, X., and Anbar, A.D., 2008, Tracing the stepwise oxygenation of the proterozoic ocean: Nature, v. 452, p. 456-459, doi:10.1038/nature06811.

Sharkey, T.D., 1996, Isoprene synthesis by plants and animals: Endeavour, v. 20, p. 74-78, doi:10.1016/0160-9327(96)10014-4.

Skinner, B.J., Erd, R.C., and Grimaldi, F.S., 1964, Greigite, the thio-spinel of iron; a new mineral: The American Mineralogist, v. 49, p. 543-555, http://www.minsocam.org/ammin/AM49/AM49_543.pdf.

Snowball, I., and Thompson, R., 1990, A mineral magnetic study of holocene sedimentation in lough catherine, northern Ireland: Boreas, v. 19, p. 127-146.

Snowball, I., and Thompson, R., 1988, The occurrence of greigite in sediments from loch Lomond: Journal of Quaternary Science, v. 3, p. 121-125, doi:10.1002/jqs.3390030203. Stephenson, R.M., 1993a, Mutual solubility of water and aldehydes: Journal of Chemical \& Engineering Data, v. 38, p. 630-633, doi:10.1021/je00012a040. 
Stephenson, P., 1993b, Plato 's fourth solid and the " pyritohedron": The Mathematical Gazette, v. 77, p. 220-226.

Sunagawa, I., 1957, Variation in the Crystal Habit of Pyrite: Report No. 175 - Geological Survey of Japan, p. 1-47.

Talbot, J., Yelle, D., Nowick, J., and Treseder, K., 2012, Litter decay rates are determined by lignin chemistry: Biogeochemistry, v. 108, p. 279-295.

Taylor, L.A., 1970, Smythite, Fe8+xS4, and associated minerals from the Silverfields mine, Cobalt, Ontario: American Mineralogist, v. 55, p. 1650-1658.

Taylor, K.G., and Macquaker, J.H.S., 2011, Iron minerals in marine sediments record chemical environments: Elements, v. 7, p. 113-118, doi:10.2113/gselements.7.2.113.

Thomas, J.E., Skinner, W.M., and Smart, R.S.C., 2003, A comparison of the dissolution behavior of troilite with other iron(II) sulfides; implications of structure: Geochimica et Cosmochimica Acta, v. 67, p. 831-843, doi:10.1016/S0016-7037(02)01146-8.

Vaughan, D.J., and Lennie, A.R., 1991, The iron sulphide minerals: their chemistry and role in nature: Science Progress Science Reviews, v. 75, p. 371-388.

Wang, W., Song, Y., Wang, X., Yang, Y., and Liu, X., 2015, Alpha-axo acids assisted transformation of $\mathrm{FeS}$ to $\mathrm{Fe}_{3} \mathrm{~S}_{4}$ implications for abiotic, biotic, and prebiotic mineralization: Astrobiology, v. 15, p. 1043-1051, doi:10.1089/ast.2015.1373.

Weinberg, M.C., Birnie, D.P., and Shneidman, V.A., 1997, Crystallization kinetics and the JMAK equation: Journal of Non-Crystalline Solids, v. 219, p. 89-99, doi:10.1016/S0022-3093(97)00261-5.

White, L.M., Bhartia, R., Stucky, G.D., Kanik, I., and Russell, M.J., 2015, Mackinawite and greigite in ancient alkaline hydrothermal chimneys: identifying potential key catalysts 
for emergent life: Earth and Planetary Science Letters, v. 430, p. 105-114, doi:10.1016/j.eps1.2015.08.013.

Xing, W., and Liu, G., 2011, Iron biogeochemistry and its environmental impacts in freshwater lakes: Fresenius Environmental Bulletin, v. 20, p. 1339-1345. 


\section{VITA}

Joseph Ashton Nolan is a father of two young men, Weston and Benjamin. The birth announcement of Weston was his inspiration to return to college after a 12-year hiatus. Joseph obtained his bachelor's degree at the University of Missouri-Kansas City in 2016 after attending Kansas University in Lawrence, KS and Lamar University in Beaumont, TX.

During Joseph's undergraduate degree, he accepted an internship at United States Geological Survey which further fueled his passion for research and prompted his continuing into a master's program. Joseph Nolan will be continuing into a Ph.D. program with the anticipation of teaching a collegiate level as well as continuing to research in his field. 